\title{
Hurricane Barriers in New England and New Jersey - History and Status After Four Decades
}

Andrew Morang

September 2007
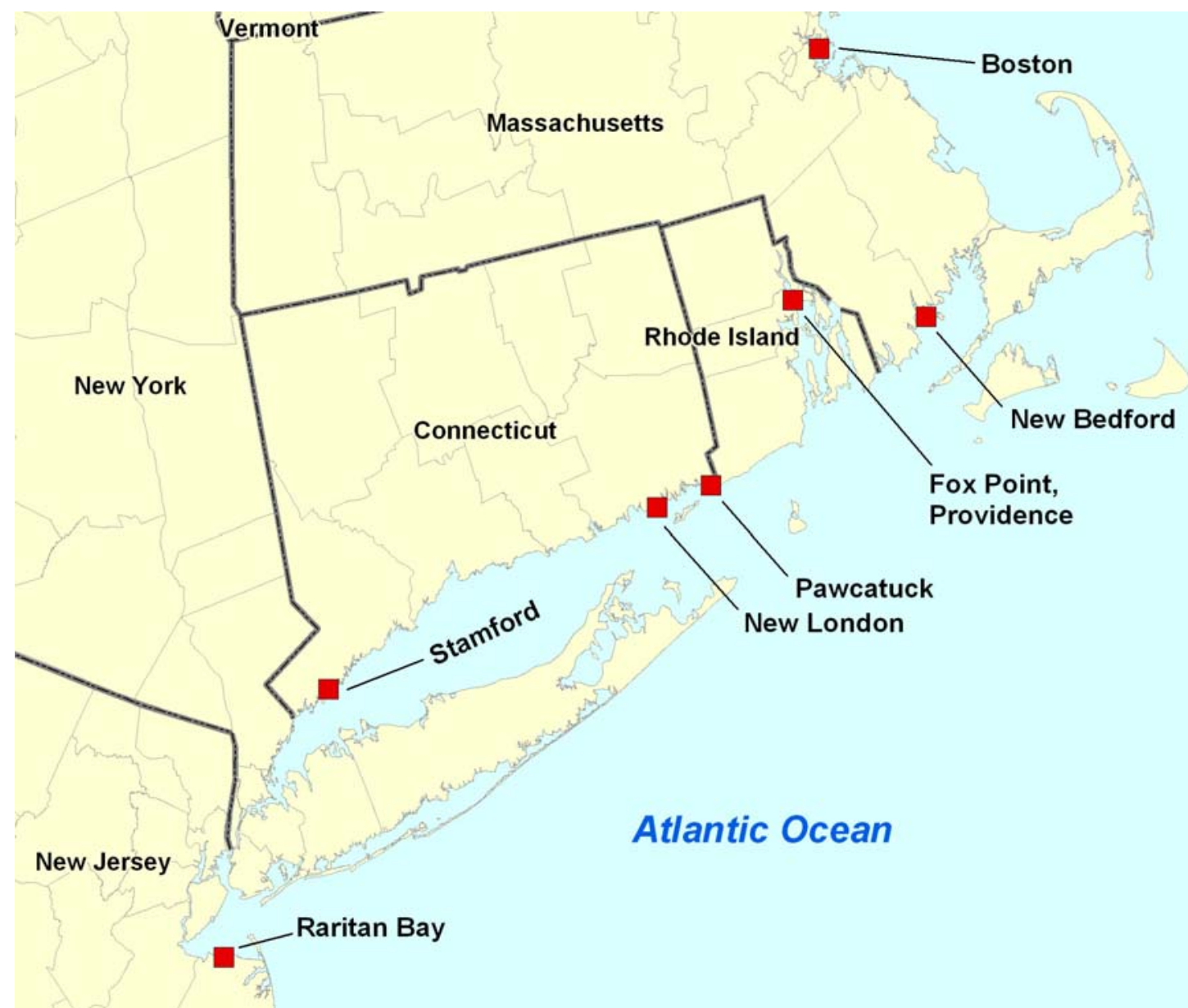


\title{
Hurricane Barriers in New England and New Jersey - History and Status After Four Decades
}

\author{
Andrew Morang \\ Coastal and Hydraulics Laboratory \\ U.S. Army Engineer Research and Development Center \\ 3909 Halls Ferry Road \\ Vicksburg, MS 39180-6199
}

Final report

Approved for public release; distribution is unlimited.

Prepared for U.S. Army Engineer District, New Orleans

7400 Leake Avenue, New Orleans, LA 70118-3651 


\begin{abstract}
In response to renewed studies of potential hurricane barriers across Lake Pontchartrain, Louisiana, the U.S. Army Engineer Research and Development Center conducted a survey of the New England hurricane barriers that revealed a number of common factors pertaining to the projects. First, most of the projects have not been tested with storm water elevations near their design elevation. Second, there is little information in the literature regarding flushing, sedimentation, or other environmental effects of the New England barriers. Third, long-term maintenance requirements were underestimated for the projects with mechanical components. Fourth, a public education campaign would be beneficial to the Corps of Engineers.
\end{abstract}

Challenges confronting designers of Gulf Coast hurricane barriers will include:

- Far more extensive environmental studies will have to be conducted today.

- Obtaining permits will be a difficult, multi-year process.

- The foundation conditions will probably be more difficult and designs will have to consider potential settlement.

- Rock was readily available for the New England projects from local quarries but will have to be brought in to the Gulf coast from distant stone sources.

- Siltation will be a greater factor in Louisiana projects.

- Post-construction project and environmental monitoring will be needed.

DISCLAIMER: The contents of this report are not to be used for advertising, publication, or promotional purposes. Citation of trade names does not constitute an official endorsement or approval of the use of such commercial products. All product names and trademarks cited are the property of their respective owners. The findings of this report are not to be construed as an official Department of the Army position unless so designated by other authorized documents. 


\section{Contents}

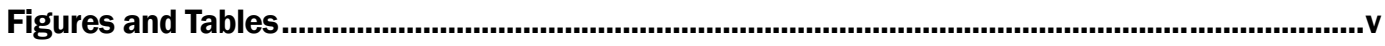

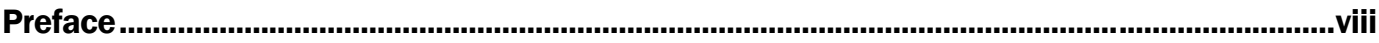

Unit Conversion Factors......................................................................................................................

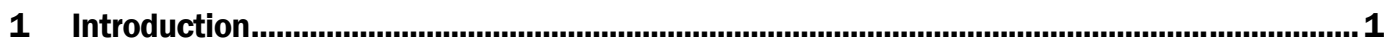

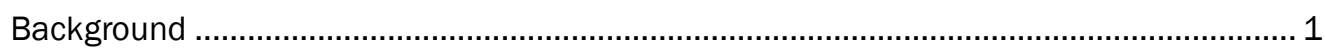

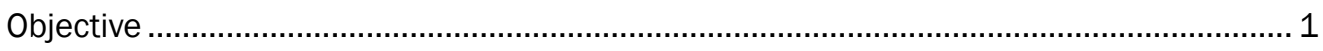

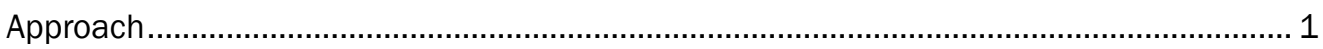

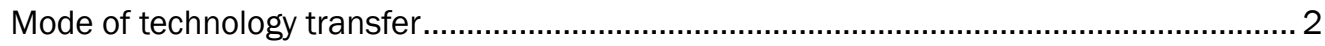

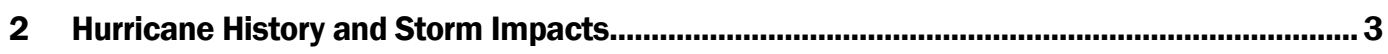

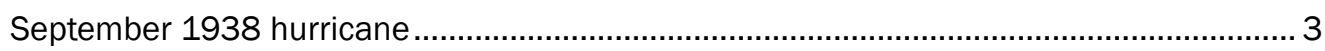

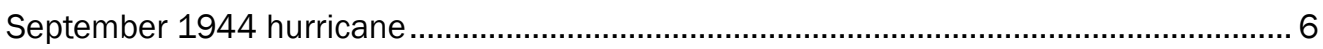

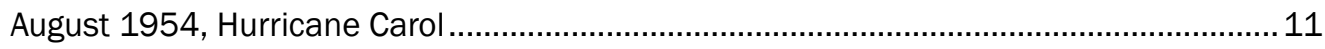

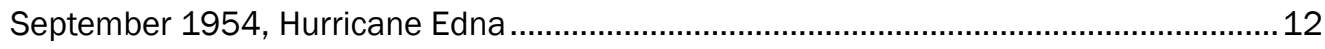

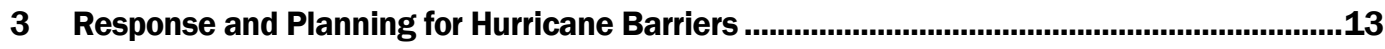

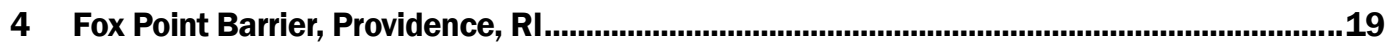

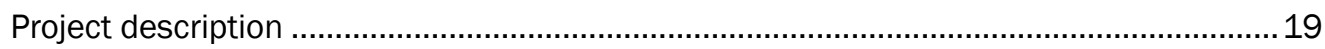

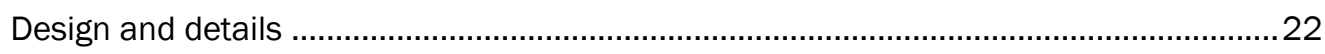

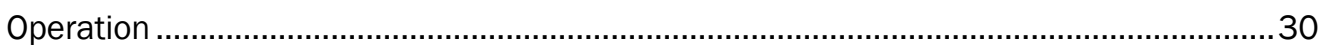

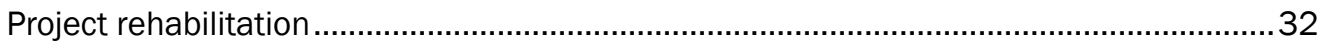

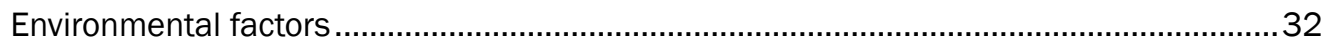

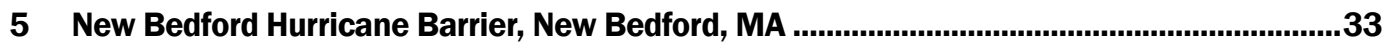

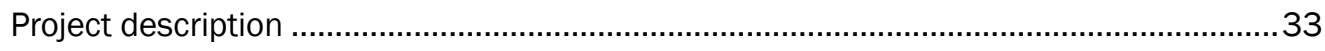

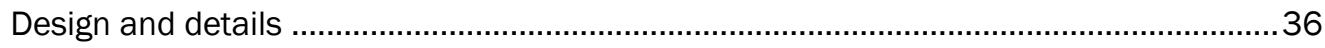

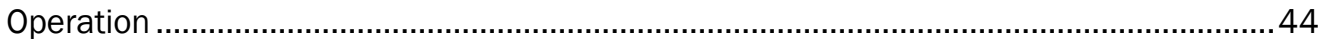

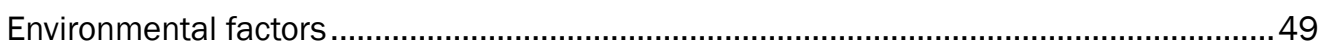

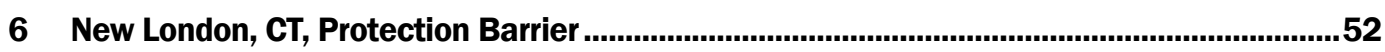

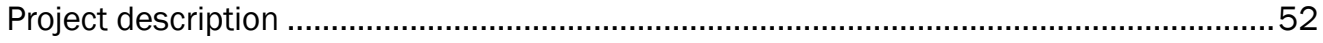

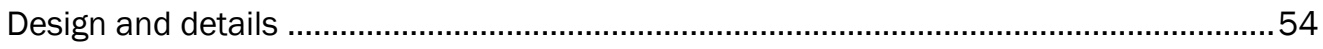

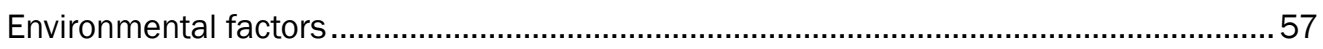

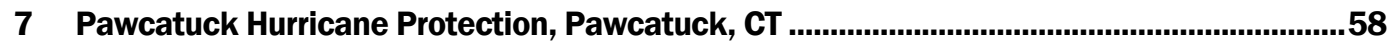

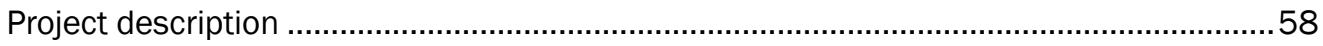

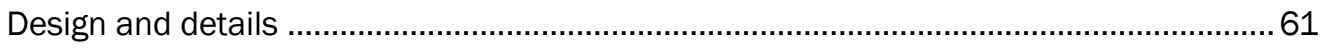

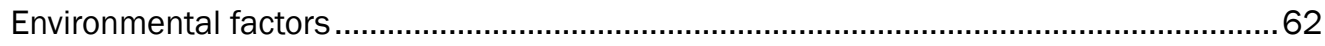

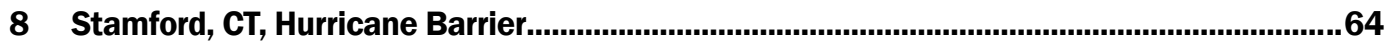




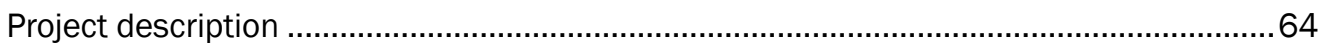

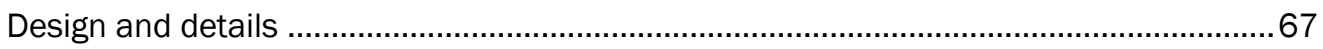

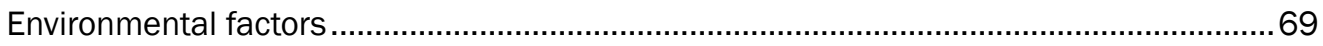

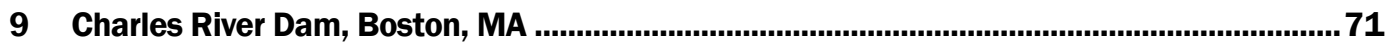

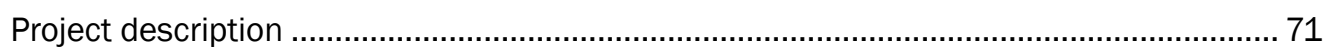

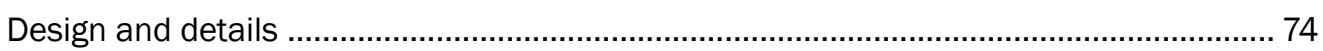

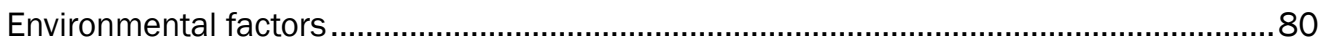

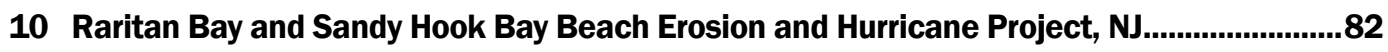

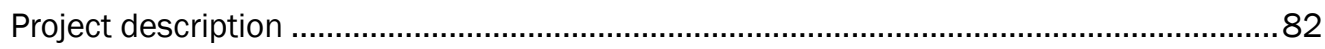

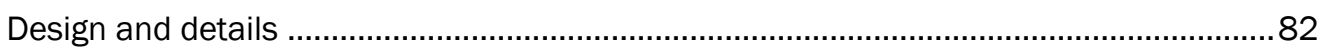

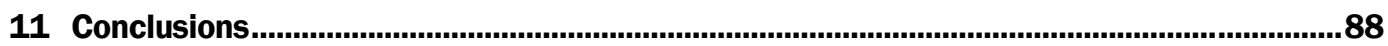

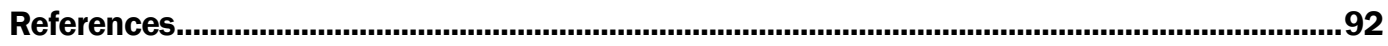

Appendix A: Bibliography of the Great New England Hurricane of 1938...................................6

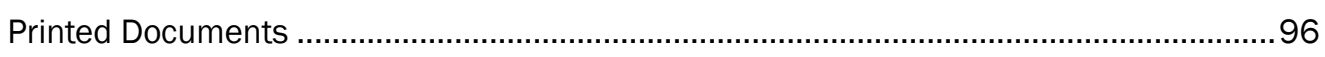

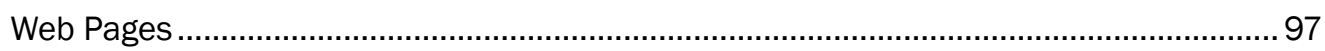

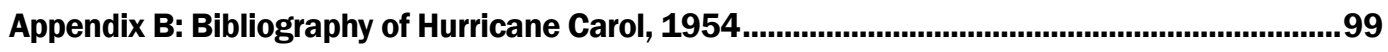

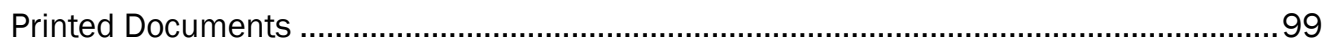

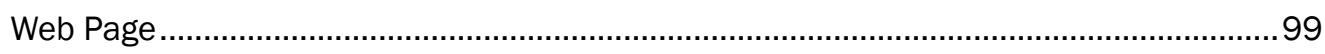

Appendix C: USACE Hurricane and Flood Potential Reports and General Design Memorandums for New England and New Jersey Coastal Waters and District of

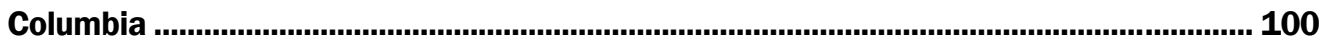

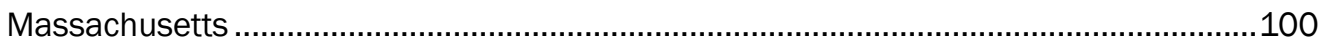

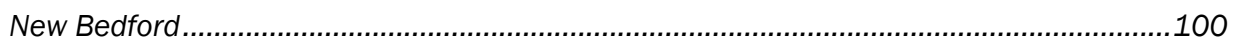

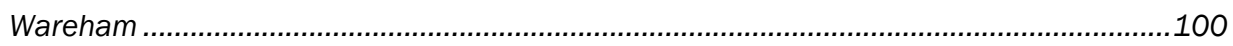

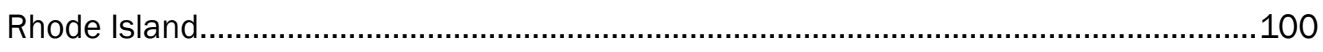

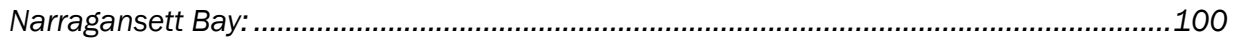

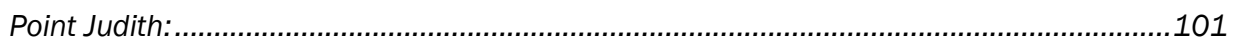

Providence:

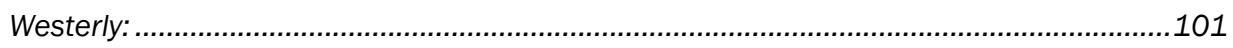

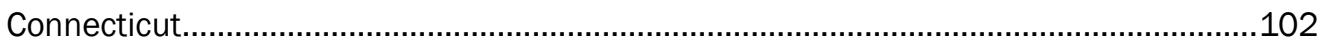

Fairfield:

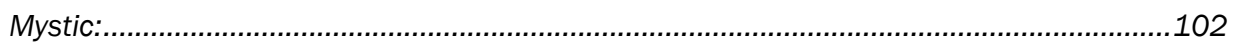

New London:

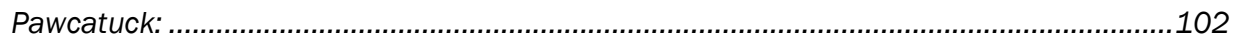

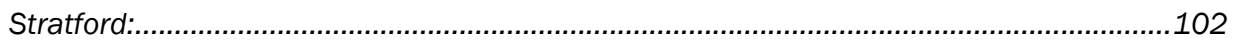

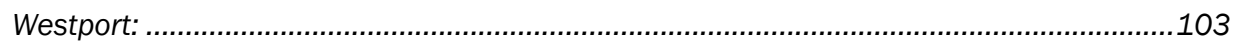

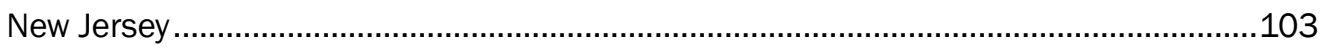

Raritan and Sandy Hook Bays:..................................................................................103

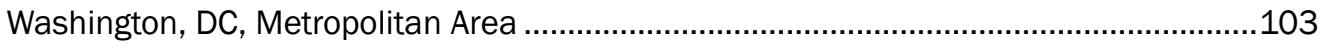

\section{Report Documentation Page}




\section{Figures and Tables}

\section{Figures}

Figure 1. New England and New Jersey hurricane barriers.

Figure 2. Tracks of prominent New England hurricanes (map from New England Division 1961).

Figure 3. Island Park, near Portsmouth, RI, was overwashed by breaker (surge?) with reported height of 30 to $40 \mathrm{ft}$. From The New England Hurricane, Federal Writers' Project of WPA, 1938 (NOAA, http://www.photolib.noaa.gov/historic/nws/nwind31.htm, 15 November 2006)

Figure 4. Seekonk River, Providence, RI, 21 September 1938. AP photograph from Providence Journal (1938)

Figure 5. Dorrance Street, downtown Providence, 21 September 1938. Photograph by L.E. Wagner, from Providence Journal (1938).

Figure 6. New Bedford damage from 1938 hurricane. Bay in background is approximately where hurricane barrier is now located. From The New England Hurricane, Federal Writers' Project of WPA, 1938 (NOAA, http://www.photolib.noaa.gov/historic/nws/nwind31.htm, 15 November 2006).

Figure 7. Proposed hurricane barriers in Narragansett Bay, RI (map from New England Division 1963).

Figure 8. Fox Point project elements, from General Design Memorandum No. 4, January 1960.

Figure 9. Fox Point hurricane barrier, view looking north toward downtown Providence. 2005 photograph predates the new l-195 bridge

Figure 10. View of Providence River (north) side of barrier with gates up (undated photograph from City of Providence)

Figure 11. Water elevations for September 1938 hurricane at Providence and Newport. Peaks were at 15.7 and $10.8 \mathrm{ft}$.

Figure 12. Water elevations for 1944 hurricane at Providence and Newport. Providence peak was $9.9 \mathrm{ft}$.

Figure 13. Water elevations for Hurricane Carol at Providence and Newport. Peaks were at

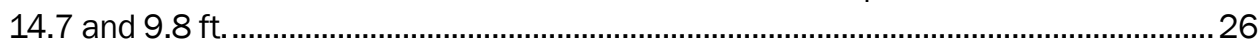

Figure 14. Providence elevation-frequency curve. ..................................................................... 27

Figure 15. Fox Point pump house, 4 November 2006..................................................................... 29

Figure 16. Pumps at Fox Point barrier, 4 November 2006 ............................................................. 29

Figure 17. Controls for pumps and equipment, Fox Point pump house, 4 November 2006.

Engineers are City of Providence employees.

Figure 18. View east from Fox Point hurricane barrier showing ramps and newly-built I195 bridge, 4 November 2006. Concrete freeway ramps substitute for some of original dike.

Figure 19. New Bedford - Fairhaven barrier plan view................................................................ 35

Figure 20. New Bedford dike and navigation gate..................................................................... 36

Figure 21. Water elevations for 1938, 1944, and 1954 hurricanes in New Bedford.......................39

Figure 22. New Bedford elevation-frequency curve...................................................................... 40 
Figure 23. Sector gate foundation work within protective cofferdam, 5 May 1964

(photograph courtesy of New England District).

Figure 24. Construction of gate house, 1964. Structure in lower right is guide for gate rollers and also contains tunnel through which gate operators can walk under channel (photograph courtesy of New England District).

Figure 25. Construction of guide for sector gates, 16 December 1964. Trucks show scale of this project (photograph courtesy of New England District).

Figure 26. Harbor side of section gate looking east toward Fairhaven, 1965

(photograph courtesy of New England District).

Figure 27. East sector gate steel erection, 15 October 1964 (photograph courtesy of New England District).

Figure 28. View looking west along New Bedford hurricane dike from gate house,

2 November 2006

Figure 29. Fishing boat passing through 150-ft-wide Federal navigation channel in New Bedford hurricane barrier. View from gate control house looking east, 2 November 2006

Figure 30. West side section gate in rest position, New Bedford hurricane barrier. Pivot is at upper center of photograph and ship channel is to right.

Figure 31. West side section gate in its well. Cogs near top of gate are engaged by teeth of opening mechanism. Silt builds up in well and has to be flushed with compressed air, but gates are often difficult to fully retreat.

Figure 32. Steel swing gate at E Rodney French Boulevard, New Bedford

Figure 33. Clark Cove pump station, operated by City of New Bedford. Grassy field in foreground serves as temporary storage after heavy rain.

Figure 34. Double-crested Cormorant resting on gate abutment, 2 November 2006.

Figure 35. New London project features (12-ft dike in south area was never built). 53

Figure 36. New London, CT, dike, 2005 (photograph courtesy of New England District). 54

Figure 37. Water elevation for 1938 and 1954 hurricanes in New London .56

Figure 38. Pawcatuck, CT, protection project elements. 59

Figure 39. Pawcatuck, CT, protection project (photograph courtesy of New England District). 60

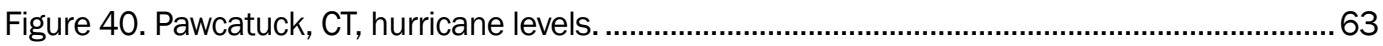

Figure 41. Stamford, CT, hurricane project elements. 65

Figure 42. Aerial photograph of Stamford hurricane barrier (photograph courtesy of New England District). 66

Figure 43. Stamford hurricane barrier (photograph courtesy of New England District)....................66

Figure 44. Stamford, CT, hurricane water levels. 70

Figure 45. Charles River, Boston, dam and hurricane protection barrier. 73

Figure 46. Charles River dam tide cycle of historical storms. Elevations on left axis are the Metropolitan District Commission local datum. This plot was drawn before Blizzard of 1978. 76

Figure 47. Original 1910 Charles River Dam, on which Boston Museum of Science was built. Charles River Basin is in foreground.

Figure 48. Charles River Dam from Charleston Bridge (Route 99), view looking south, 1 November 2006. Brick structure contains pumps. Water in foreground is tidal. 
Figure 49. Charles River Dam harbor side, view from Boston shore looking NW,

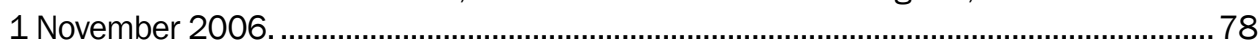

Figure 50. West side of Charles River Dam pump house, 1 November 2006................................. 78

Figure 51. Navigation lock, Charles River Dam, view looking east towards Boston Harbor,

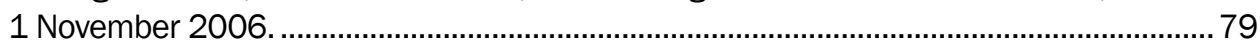

Figure 52. Diesel engines and pumps in Charles River Dam, 1 November 2006. .......................... 79

Figure 53. Raritan Bay project elements (from USACE digital project notebook). Sawtooth pattern represents levees. Fill and Levees in Matawan Township and fill in Union Beach (in red) were never built. North is to top.

Figure 54. Storm frequency curve for Raritan Bay (from interim hurricane study, New York District 1960). Design elevation of surge added to high tide was +12.9 ft MSL. .............. 86

Figure 55. Bayshore floodgate and pump station, at junction of Waackaach and Thorns Creeks. From New Jersey Deparatment of Environmental Protection ( http://www.state.nj.us/dep/shoreprotection/bayshore.htm, 8 January 2007).

Figure 56. Pump house at Bayshore Floodgate Facility. From NJ Dep

( http://www.state.nj/dep/shoreprotection/bayshore.htm, 8 January 2007).

\section{Tables}

Table 1. Water elevations, Fox Point hurricane barrier, Providence, RI.......................................... 23

Table 2. Water elevations, New Bedford, MA, hurricane barrier. ......................................................38

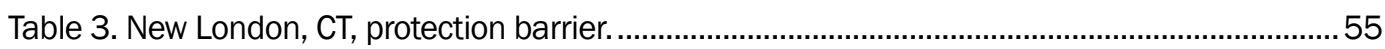

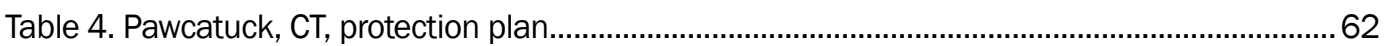

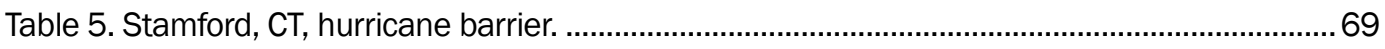

Table 6. Charles River, Boston, MA, dam and local protection project...............................................75

Table 7. Summary of hurricane barrier project features.................................................................... 89

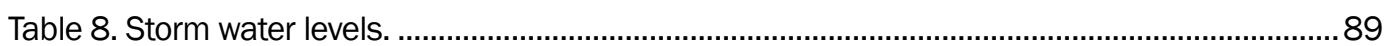




\section{Preface}

The USACE has built and operated hurricane barriers in Rhode Island, Massachusetts, Connecticut, and New J ersey for almost four decades. The purpose of this study was to examine these older projects, assess their characteristics and function, and make this information available to the engineering teams involved in the LACPR planning.

Following the flooding and property damage caused by Hurricanes Katrina and Rita in September 2005, the U.S. Army Engineer District, New Orleans, of the U.S. Army Corps of Engineers (USACE) has been tasked to evaluate if a system of hurricane levees, barriers, and gates could protect Lake Pontchartrain and the City of New Orleans from future storms. On the Louisiana Coastal Protection and Restoration (LACPR) Project, the USACE has been working with the State of Louisiana in soliciting input from the public on various alignments and assembling these concepts into alternatives for evaluation. The team will identify specific engineering and design features required to build structures along these alignments. The team will also have to make assumptions of the construction methods required in order to develop cost estimates.

Dr. Andrew Morang of the U.S. Army Engineer Research and Development Center (ERDC), Coastal and Hydraulics Laboratory (CHL), Vicksburg, MS, conducted the study and prepared this report. Edmond Russo, Lisa Hubbard, and Dinah McComas, CHL; Dubán Montoya, U.S. Army Engineer District, New England (NAE); Christina Rasmussen, U.S. Army Engineer District, New York (NAN); and Richard DiBuono (USACE, retired) reviewed the report.

At CHL, work was performed under the general supervision of Dr. Lisa Hubbard, Chief, Coastal Engineering Branch, CHL; Dr. Rose Kress, Division Chief, Navigation Division, CHL; Dr. William D. Martin, Deputy Director, CHL; and Thomas W. Richardson, Director, CHL. Edmond Russo was program manager for the LACPR program. J. Holley Messing, Coastal Engineering Branch, Navigation Division, CHL, completed word processing and formatting. 
The author wishes to thank Richard J. DiBuono and Richard Sager, USACE (retired), J ames E. Law, Dubán Montoya, and J ohn Winkelman, all NAE, Ms. Abigail M. Clark, NAE, and Ms. Christina Rasmussen, NAN, for information, historical data, and advice. Steven R. Fluegel, NAE, escorted the author on a tour of the New Bedford project.

COL Richard B. J enkins was Commander and Executive Director of ERDC. Dr. J ames R. Houston was Director. 


\section{Unit Conversion Factors}

\begin{tabular}{|l|c|l|}
\hline Multiply & By & To Obtain \\
\hline acres & 0.4047 & hectares \\
\hline cubic yards & 0.7645549 & cubic meters \\
\hline cubic ft per second (cfs) & 448.83 & gallons per minute \\
\hline feet & 0.3048 & meters \\
\hline inches & 0.0254 & meters \\
\hline miles (U.S. statute) & $1,609.347$ & meters \\
\hline
\end{tabular}




\section{Introduction}

\section{Background}

The U.S. Army Corps of Engineers (USACE) has constructed seven hurricane protection projects to prevent flooding during hurricanes and other unusually high water events in New England and NewJ ersey. The New England projects are in Boston, MA; New Bedford, MA; Providence, RI; Pawcatuk, CT; New London, CT; Stamford, CT; and Raritan Bay, NJ (Figure 1). Two of the projects, New Bedford and Stamford, are currently operated by the U.S. Army Engineer District, New England (hereafter, New England District) while the others are owned and operated by city agencies. The New England District (formerly New England Division or NED) was a pioneer in the construction of hurricane barriers in the United States. The U.S. Army Engineer District, New York (hereafter New York District) project is in Lawrence Harbor (previously named Madison), Kenasburg, and North Middletown (previously named East Keansburg) Townships, NJ , facing Raritan and Sandy Hook Bays.

\section{Objective}

The purpose of this report is to:

1. Describe the meteorological and historical conditions that led to the authorization and construction of hurricane barriers.

2. Provide background information on the location and design of the barriers.

3. Evaluate lessons learned after four decades of operation.

\section{Approach}

The author completed the objectives of this project by:

1. Reviewing books, articles, and other historical materials pertaining to hurricanes and severe meteorological events in New England.

2. Summarizing design information from General Design Memoranda and other reports that were prepared before and during construction of the projects.

3. Visiting three of the projects, interviewing New York and New England District personnel, and reviewing recent documents on the projects. Some 
of the photographs and notes in this document are based on the author's visit to the project sites in Boston, New Bedford, and Providence, in November 2006.

\section{Mode of technology transfer}

This report will be included in the technical appendices of the Louisiana Coastal Protection and Restoration Program December 2007 Technical Report being prepared by the U.S. Army Engineer District, New Orleans. It will also be available as printed copies and through the World Wide Web at http:// chl.erdc.usace.army.mil.

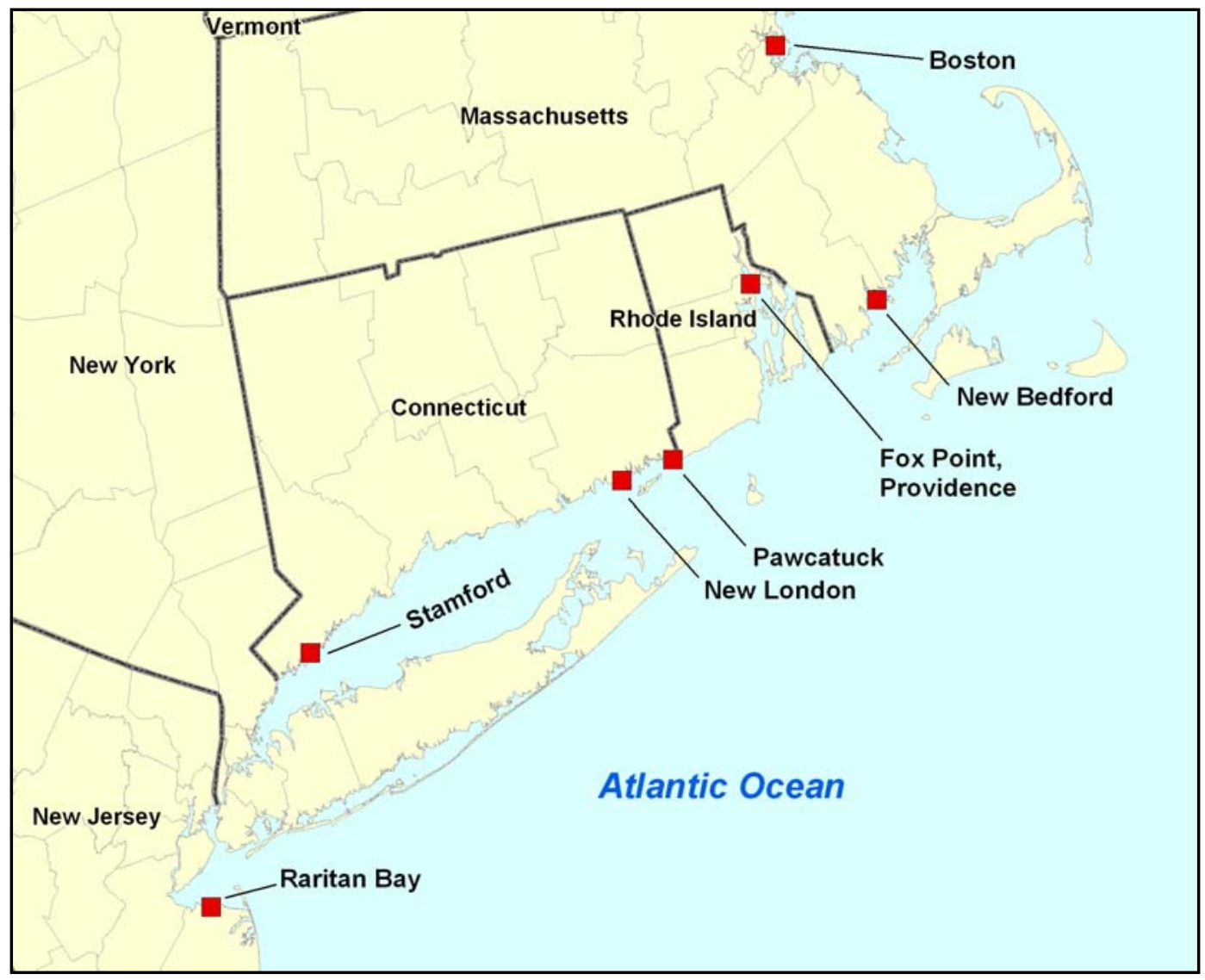

Figure 1. New England and New Jersey hurricane barriers. 


\section{Hurricane History and Storm Impacts}

The New England and NewJ ersey hurricane barriers were authorized in response to flooding, property damage, and loss of life that resulted from three highly destructive hurricanes: the Great New England Hurricane of September 1938 (also known as the "Long Island Express"); the Great Atlantic Hurricane of September 1944; and Hurricane Carol in August 1954.

\section{September 1938 hurricane}

The Great New England Hurricane of 21 September 1938, was one of the seminal meteorological events in New England's 20th century history. The storm caused unprecedented damage throughout New England and Long Island, killing over 600 people and devastating coastal communities along the open Atlantic shore, Long Island Sound, Block Island Sound, Narragansett Bay, and Buzzards Bay (Allen 1976; Federal Writers' Project 1938; Minsinger 1988). The damage was beyond anything northeast coastal residents had experienced or recorded. Throughout New York and New England, the wind and water felled 275 million trees, seriously damaged more than 200,000 buildings, knocked trains off their tracks, and beached thousands of boats (Haberstroh 1998).

Various writers have estimated damage from the storm at $\$ 600$ million, in 1938 dollars. Pielke and Landsea (1998) estimated damage of \$306 million for the affected coastal counties (excluding inland damage). They recalculated the loss to be $\$ 16.6$ billion in 1995 dollars by normalizing the damage by inflation, personal property increases, and coastal county population changes. Therefore, if we double their base damage estimate to $\$ 600$ million to include inland counties that experienced flooding, the normalization to 1995 dollars might be in the range of $\$ 32$ billion. Considering that wind and rain damage extended as far north as Rutland, VT, entire city blocks burned in New London and other industrial towns, and downtown Providence, Hartford, and other cities were flooded, if this storm were to occur in 2007 to a much more highly industrialized and urbanized New England, the cost would be much higher.

This storm was first detected as a tropical depression off the Cape Verde Islands. On 15 September, it was east of Puerto Rico and was upgraded to 
a hurricane. Florida residents began to make preparations, but by the 20th, the system curved northward towards the Carolinas. A low pressure trough moving out of the Great Lakes had enough strength to steer the hurricane away from the coast. Further out to sea, a Bermuda high was in place, with the result that the hurricane was squeezed between these two systems and accelerated north, not out into the open Atlantic. The storm moved up the Atlantic seaboard at over $50 \mathrm{mph}$, therefore gaining the name “Long Island Express."

On the 20th, seas and winds along the New England shore were not particularly high, and New England and Long Island coastal residents had little warning that severe weather was headed their way. The winds grew gradually during the morning of the 21st, but by late that afternoon, 80-100 mph winds crushed houses, knocked down trees, and lifted barges and boats onto land. The eye of the storm crossed Long Island between Moriches and the present Shinnecock Inlets. ${ }^{1}$ Hurricane force winds were felt throughout New England, and a gust of 186 miles per hour was recorded at the Blue Hills Observatory in Milton, MA. By the 22nd, the storm had moved north into southern Canada and dissipated much of its energy, but had left a path of forest destruction (Figure 2). This storm was a category 3.5 on the Saffir-Simpson scale upon landfall on Long Island (J arvinen 2006). More detailed meteorological information can be found in Tannehill (1938), Pierce (1939), Wexler (1939), Paulson (1940), and Myers and J ordan (1956). Harris (1963) documented high water survey and tide data. Appendix A lists references on the 1938 hurricane, including social histories and memoirs.

Much of the inland flooding was not caused by the hurricane itself. Rainfalls of over $1 \mathrm{in}$. had fallen over broad areas of southern and central New England on both 12 and 15 September, causing a significant rise in river levels. On 17-20 September, another storm dropped more than 6 in. rainfall, sufficient to produce flooding over many river basins throughout New England. ${ }^{2}$ The stage was set for the hurricane on the 21st, which dropped another $6+$ in. of rain. The Thames River drainage in Connecticut, where over 13 in. of rain was recorded, was particularly hard hit, resulting in some of the worst flooding ever recorded. The Connecticut

\footnotetext{
1 One of the enduring geological effects of the Great New England Hurricane was the cutting of the barrier beach south of Shinnecock Bay, which, after man-made stabilization, became the present Shinnecock Inlet (Morang 1999).

2 Data from NOAA, http://ahps.erh.noaa.gov/nerfc/historical/sept1938.htm, 15 November 2006.
} 
River, in Hartford reached a level of $35.4 \mathrm{ft}$, which was $19.4 \mathrm{ft}$ above flood stage. ${ }^{1}$

Coastal residents suffered the greatest from the storm because the surge coincided almost exactly with the autumnal high tide. Long Island and southern Rhode Island residents reported that a 25- to 40-ft wall of water overwashed the barrier islands with virtually no warning (Allen 1976). Along the southern Rhode Island shore, entire beach communities were washed away, and this author has seen remnants of chimneys and foundations exposed in the sand on East Beach, RI, after winter storms. The surge funneled up Narragansett Bay, causing untold damage to East Greenwich, Barrington, Warwick, and Portsmouth (Providence J ournal 1938; Figure 3). The business district of Providence was flooded with over $14 \mathrm{ft}$ of water, submerging trolley cars, automobiles, and the ground floors of buildings (Figures 4 and 5). The incoming water entered the city so swiftly, within $10 \mathrm{~min}$ the downtown was engulfed, trapping people in the upper floors of buildings, and, tragically, in automobiles. It was almost 2 weeks before many stores and businesses could dig out debris, pump flooded basements, restore electricity, and resume business. New Bedford was similarly inundated, and the fishing fleet largely destroyed (Figure 6).

Viewing these events after six decades, we wonder, why were people caught so unawares by this storm? Three factors may account for the tragedy. First, the storm moved quickly up the coast from Florida to New England, and weather forecasters, without the benefit of satellites or storm-chasing aircraft, were unable to track it effectively. In that era, many forecasters discounted the possibility of a hurricane making landfall in New England, and the weather service was accused of grossly underestimated the danger of the storm and not issuing adequate warnings. Since then, researchers have found geological and documentary evidence that New England suffered periodic damaging hurricanes dating back over 700 years (Donnelly et al. 2001, Ludlum 1963). Second, because the storm moved so rapidly, radio stations and newspapers were unable to spread warnings to all the affected areas. The afternoon newspapers had not yet been distributed by the time the storm struck Long Island. Finally, an intriguing note from Clowes (1939; p. 60), "However, reports received by the Weather Bureau indicate that owing to the general alarm over the

1 The author's father worked for the Providence District at this time and was assigned to stream gauging in the Connecticut valley. He wrote in his diary that many roads in Connecticut were under water, washed out, or impassible because of fallen trees and other debris. 
European situation the public took little interest in news regarding the weather." On 21 September 1938, the Czechoslovakian parliament had capitulated to Adolf Hitler and accepted cession of the territories with a German-speaking majority. Prime Minister Neville Chamberlain flew to Munich to negotiate with Hitler about the partition of Czechoslovakia in the attempt to avert war (Churchill 1948). Americans and Europeans, terrified that another world war might break out, anxiously listened to the wireless broadcasts from Germany hoping that Chamberlain might appease the German dictator.

\section{September 1944 hurricane}

The "Great Atlantic Hurricane of 1944" followed a track along the Atlantic seaboard similar to the 1938 hurricane and two earlier events, in 1815 and 1821 (Brooks and Chapman 1945). The storm pattern was first detected as a hurricane on 4 September 1944. It strengthened to Category 4 on 12 September and made landfall as a Category 3 near Cape Hatteras, NC. The storm made a second landfall on eastern Long Island on 14 September after causing significant damage in NewJ ersey. The storm progressed northeast, passing north of Boston and moving out into the Gulf of Maine (Figure 2). Of the 390 people who perished, 340 were lost on ships at sea. Low-lying areas of New Bedford and Buzzards Bay were inundated. The water level in New Bedford was recorded at $11.5 \mathrm{ft}$, and Buzzards Bay levels would have been higher if the Cape Cod Canal had not allowed water to escape to Cape Cod Bay.

The low death toll on land was due to well-executed warnings and evacuations, a result of the bitter lessons of 1938. However, along the J ersey shore, thousands of houses and businesses were destroyed and damaged. Pielke and Landsea (1998) calculated the total damage in 1995 dollars to be $\$ 6.5$ billion. 


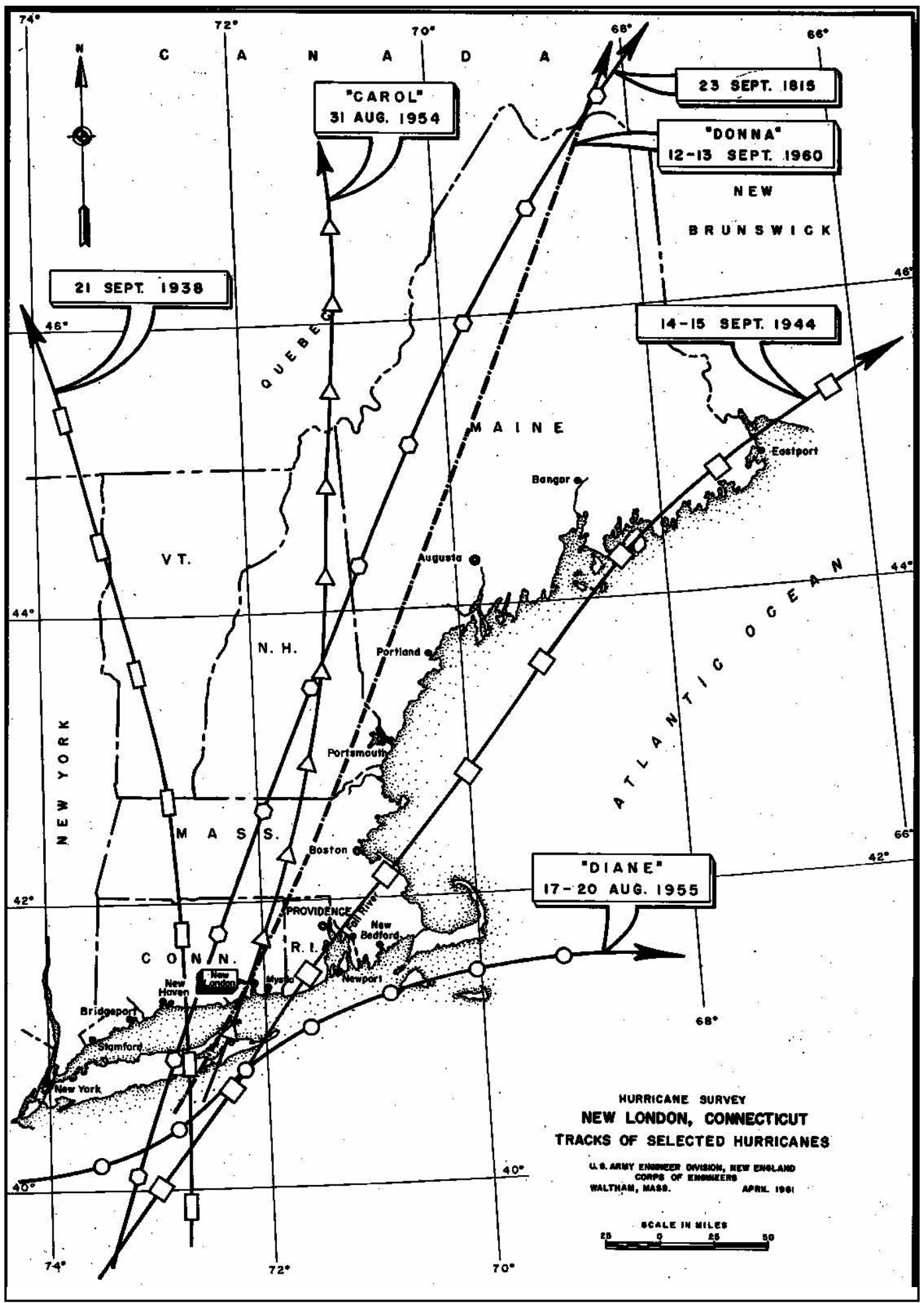

Figure 2. Tracks of prominent New England hurricanes (map from New England Division 1961). 


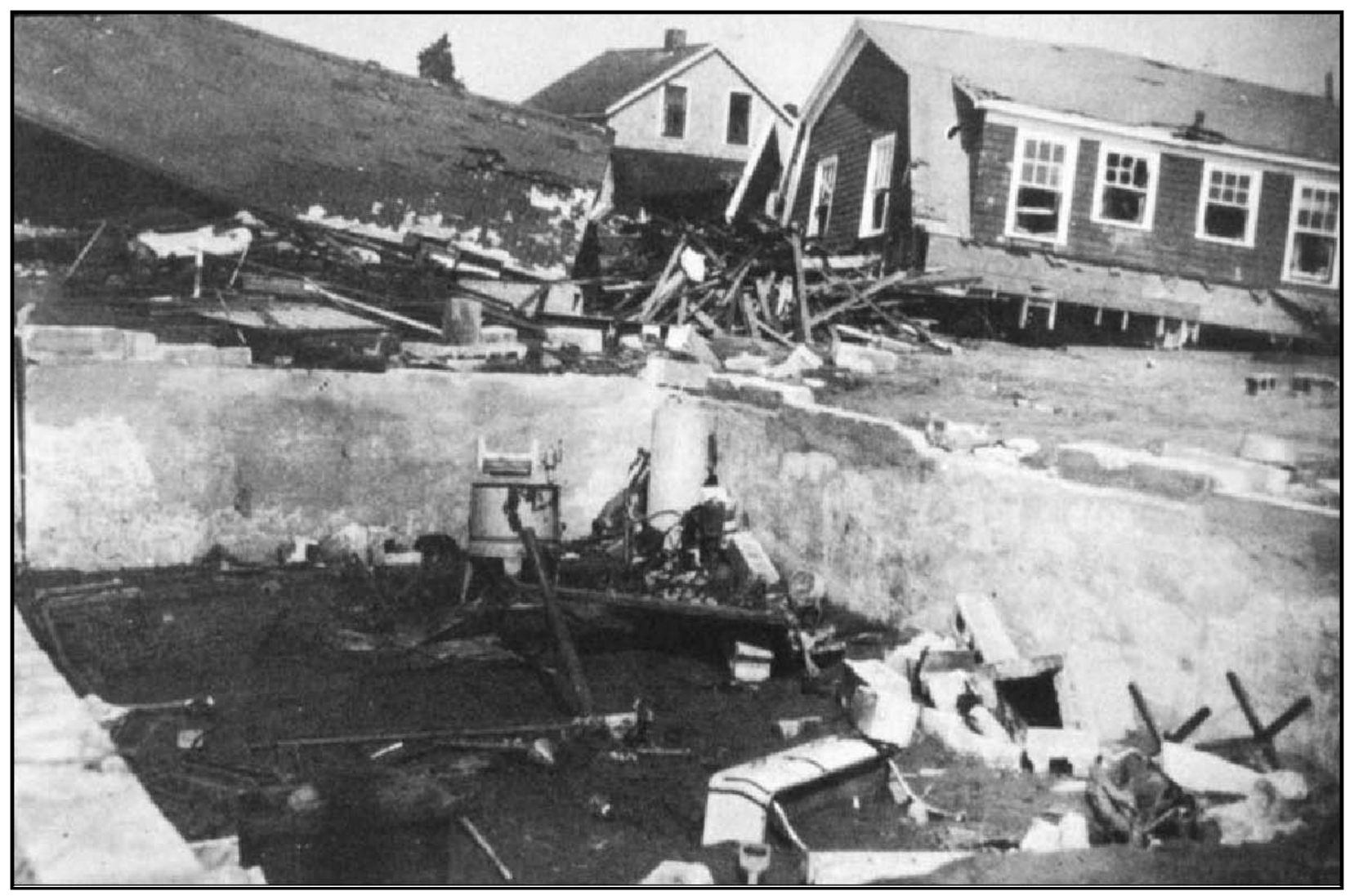

Figure 3. Island Park, near Portsmouth, RI, was overwashed by breaker (surge?) with reported height of 30 to $40 \mathrm{ft}$. From The New England Hurricane, Federal Writers' Project of WPA, 1938 (NOAA, http://www.photolib.noaa.gov/historic/nws/nwind31.htm, 15 November 2006). 


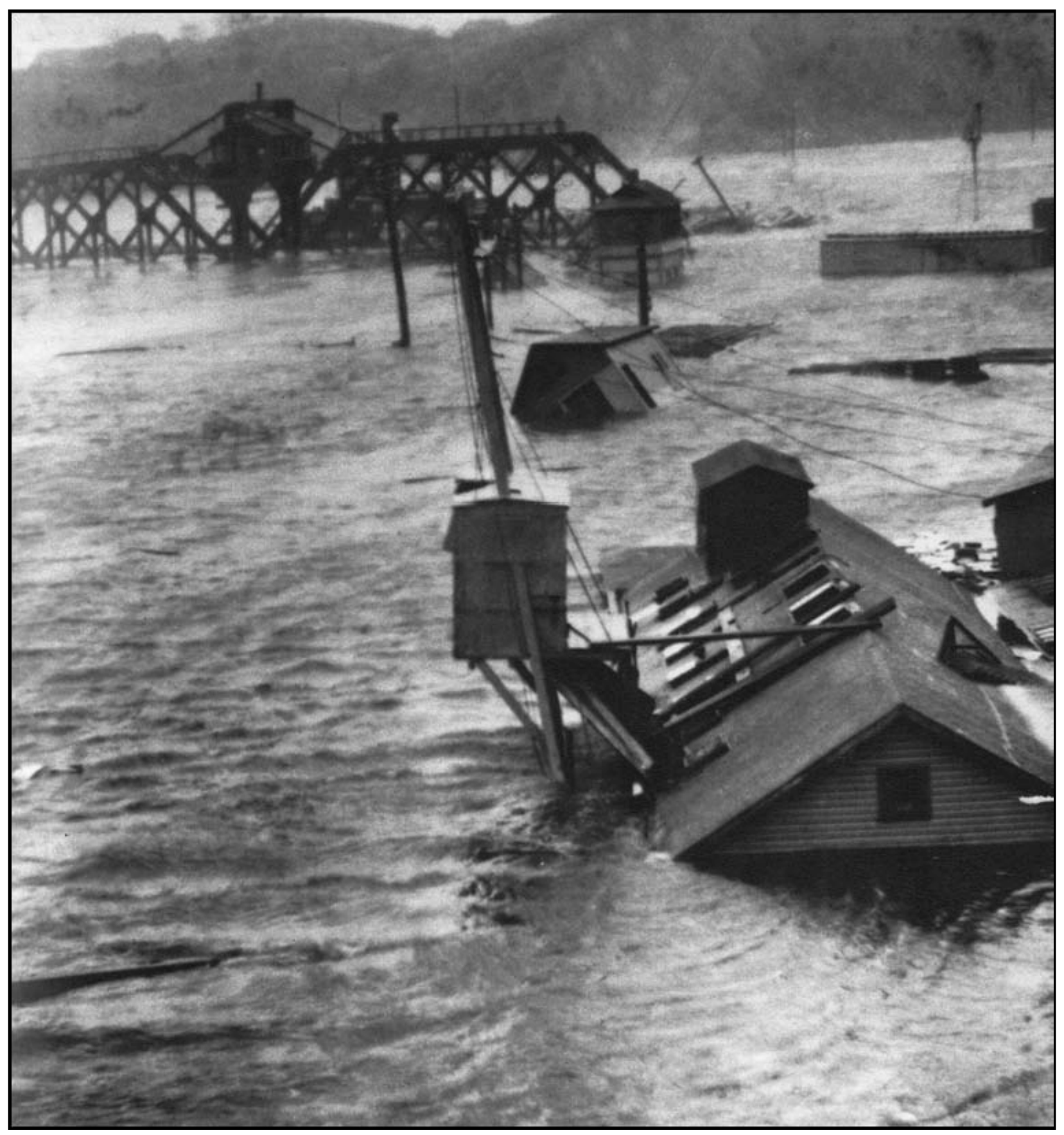

Figure 4. Seekonk River, Providence, RI, 21 September 1938. AP photograph from Providence Journal (1938). 


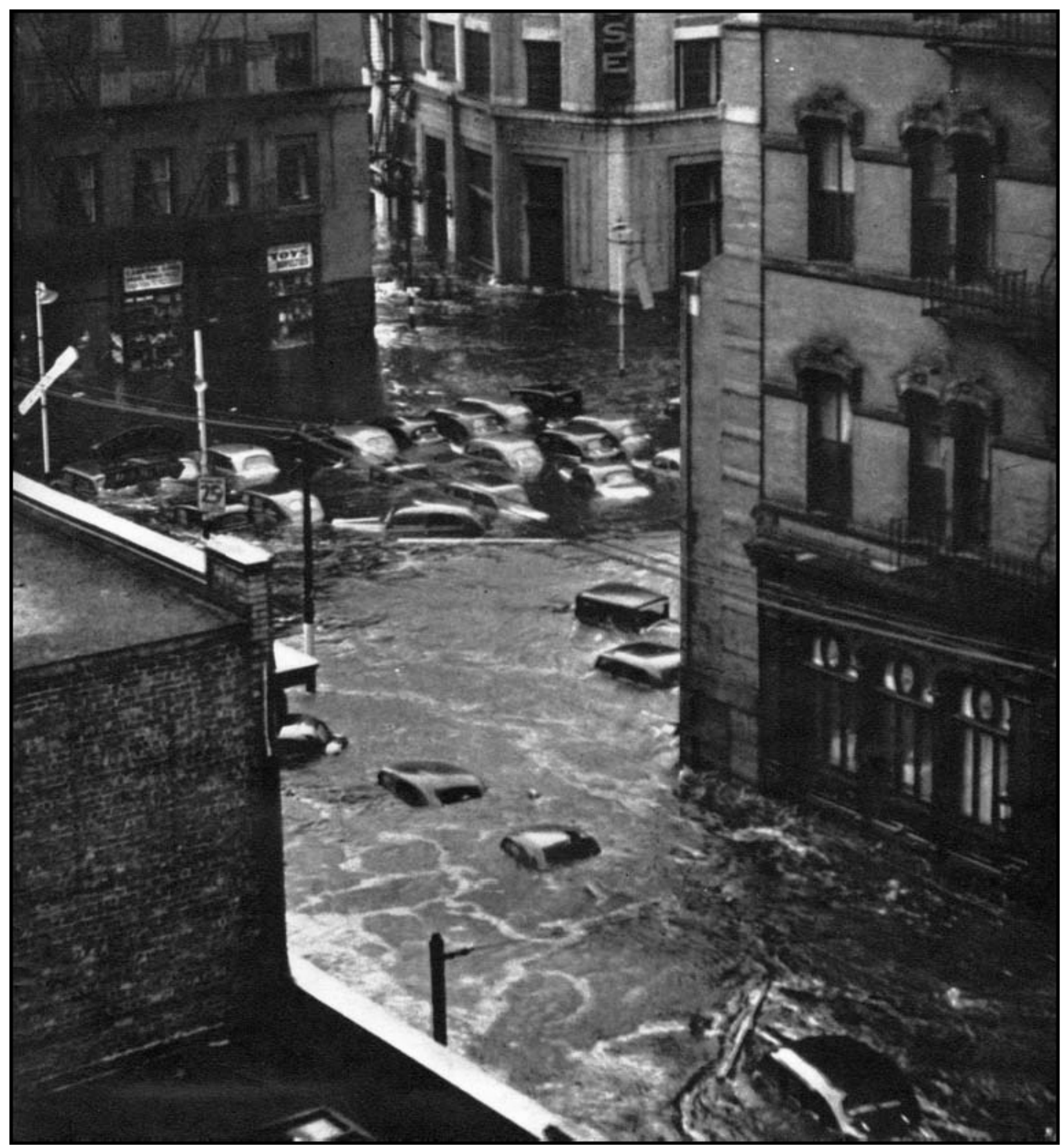

Figure 5. Dorrance Street, downtown Providence, 21 September 1938. Photograph by L.E. Wagner, from Providence Journal (1938). 


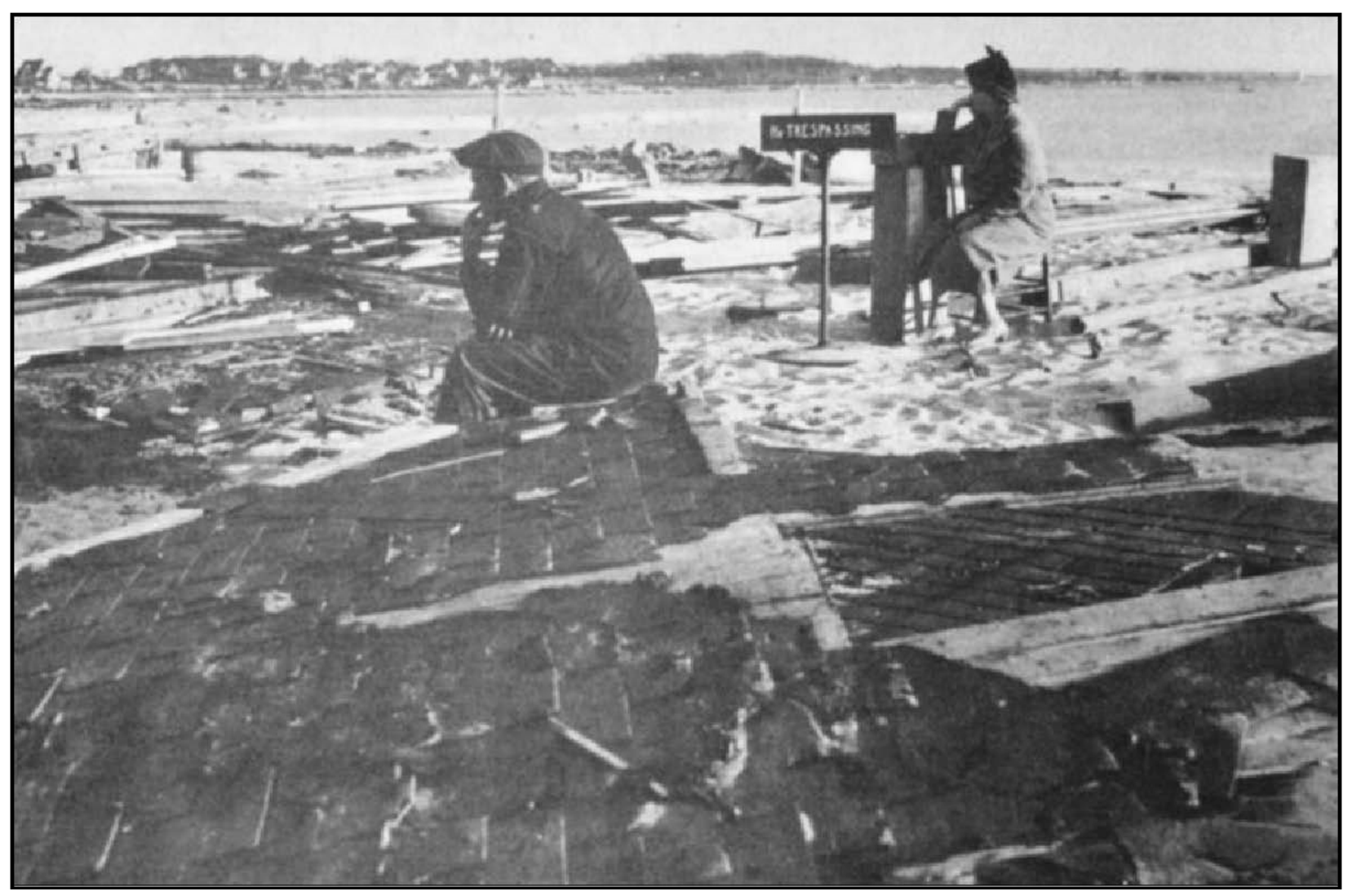

Figure 6. New Bedford damage from 1938 hurricane. Bay in background is approximately where hurricane barrier is now located. From The New England Hurricane, Federal Writers' Project of WPA, 1938 (NOAA, http://www.photolib.noaa.gov/historic/nws/nwind31.htm, 15 November 2006).

\section{August 1954, Hurricane Carol}

Hurricane Carol was first detected as a tropical storm near the Bahamas on 25 August 1954. After drifting northwest, it gained energy and accelerated to the north on 30 August. It struck Long Island as a category 3 on 31 August with wind speeds approaching $120 \mathrm{mph}$. The eye passed over Groton, CT, at 10:00 a.m. on 31 August (J arvinen 2006; Figure 2). Similar to 1938, many areas reported a storm surge of 10-15 ft. As summarized by NOAA: ${ }^{1}$

Hurricane Carol arrived shortly after high tide, causing widespread tidal flooding. Storm surge levels ranged from 5 to $8 \mathrm{ft}$ across the west shore of Connecticut, and from 10 to $15 \mathrm{ft}$ from the New London area eastward. Storm tide profiles show, as in 1938,

1 From NOAA, http://www.erh.noaa.gov/box/hurricanecarol.htm, 24 November 2006, information from Vallee and Dion (1998). 
how dramatically the tides increased just before landfall across Narragansett Bay, the Somerset, Massachusetts area and in New Bedford, Massachusetts, harbor. Narragansett Bay and New Bedford harbor received the largest surge values of over $14 \mathrm{ft}$ in the upper reaches of both water ways. On Narragansett Bay, just north of the South Street Station site, the surge was recorded at $14.4 \mathrm{ft}$, surpassing that of the 1938 hurricane. However, since Hurricane Carol arrived after high tide, the resulting storm tide was lower. Coastal communities from central Connecticut eastward were devastated. Entire coastal communities were nearly wiped out in New London, Groton, and Mystic, Connecticut, as well as from Westerly to Narragansett, Rhode Island. Once again, as in the 1938 hurricane, downtown Providence, Rhode Island, was flooded under $12 \mathrm{ft}$ of water.

Because of Carol's rapid northward motion, residents had little warning. The Boston Weather Service did not issue a hurricane warning for New England coastal areas until 10:30 a.m., and by then, it was too late for some Rhode Islanders. In Oakland Beach, RI, water had already risen and flooded first floors by 9:30 a.m., and by 10:45, only $15 \mathrm{~min}$ after the official warning, $100 \mathrm{mph}$ winds were lashing homes and trees. By 11:00, water was rising in downtown Providence, and at 11:45, the flood rose within a foot of the high-water mark from the 1938 hurricane. Carol's storm surge wiped out businesses and destroyed 3,500 cars downtown (Carbone 2004). In New Bedford, the fishing fleet and other coastal businesses sustained heavy damage for the third time in only two decades. Pielke and Landsea (1998) computed damage to be $\$ 9.0$ billion in 1995 Dollars. Appendix B lists more references on this hurricane.

\section{September 1954, Hurricane Edna}

Residents of New England were still cleaning up after Hurricane Carol when Edna formed off South America. A deep atmospheric trough off the east coast helped direct Edna Rapidly northward along the Atlantic Seaboard. The eye passed between Nantucket and Martha's Vinyard at 3:30 p.m. on 11 September. Fortunately, the storm coincided with low tide and storm surges did not form. The worst damage from Edna occurred in Maine, where heavy rains in excess of 8 in. filled the watersheds. The Kennebeck, Androscoggin, and other rivers washed out bridges and flooded historic mill towns. Twelve people died in New England. 


\section{Response and Planning for Hurricane Barriers}

It is unclear from the records if hurricane barriers were conceived or planned after the devastation of the 1938 hurricane. If plans were begun, political infighting and World War II put them on hold.

In the late 1930s, the Federal government was embroiled in controversy over the construction of flood control reservoirs for inland waters (Parkman 1978). The winter of 1935-1936 was one of the most severe that New England had ever experienced, and intense March storms lashed the eastern and central parts of the United States, causing unprecedented damage and disruption. Life in the Connecticut River Valley was essentially paralyzed with 77,000 people left homeless, railroads destroyed, and the National Guard occupying major cities to keep order. This led, for the first time, to widespread calls for aggressive federal action to prevent such tragedies in the future. The result was the Flood Control Act of 1936, which assigned new responsibilities to the Federal government and new duties to the Corps of Engineers. After bitter debates concerning ownership and operation of reservoirs and dams, the Flood Control Act of 28 J une 1938, stipulated these structures, unless otherwise provided by law, would be constructed entirely at federal cost and would be owned, maintained, and operated by the Federal government.

But, before any flood-control construction had begun, the 1938 hurricane pummeled Providence and other south shore communities. Parkman (1978; p. 179) writes:

"Rather than hastening reservoir construction, the disaster led instead to further delay. The elections of 1938 were only weeks away, and the floods offered an irresistible issue. Though no reservoirs authorized in 1936 could have been completed in any event, Republican candidates blamed the delay in giving New England flood protection on the New Deal generally and on the region's Democratic congressional opponents of the interstate compacts in particular. This was deadly campaign stuff at a time when thousands of people were still reckoning their losses, and 
Democratic leaders in Connecticut, New Hampshire, and Massachusetts made desperate appeals to Roosevelt for help."

Construction of some projects along rivers followed, but World War II soon siphoned funds from civil works projects, and many Corps engineers were reassigned to the war effort. By 1943, work on reservoirs and civil projects came to an end.

The 1944 hurricane again revealed how vulnerable many coastal towns were to storm surges. The record is incomplete on whether there were calls for Federal coastal flood protection at that time. The Flood Control Act of 1944 (P.L. 78- 534), enacted in the 2nd Session of the 78th Congress and signed into law by President Roosevelt in December 1944, authorized construction of numerous dams and levees across the United States and led to the establishment of the Pick-Sloan Missouri Basin Program. Pursuant to this law, the Secretary of War submitted a report to Congress on protection of the NewJ ersey coast due to tides and winds, but concluded that a project was not advisable at that time (New York District 1963). We do not know if reports for other parts of the country were submitted to Congress in the mid-1940s.

Finally, after Hurricanes Carol and Edna in 1954 again demonstrated the vulnerability of coastal areas, Congress was compelled to act. The 84th Congress (1st Session, Public Law 71, 15J une 1955) authorized and directed the Secretary of the Army, with cooperation of other Federal agencies, to conduct surveys and studies of damages, causes, and remediation measures with regard to hurricanes:

\section{SEC. 1. Be it enacted by the Senate and House of} Representatives of the United States of America in Congress Assembled. That in view of the severe damage to the coastal and tidal areas of the eastern and southern United States from the occurrence of hurricanes, particularly the hurricanes of August 31, 1954, and September 11, 1954, in the New England, New York, and New J ersey coastal and tidal areas, and the hurricane of October 15, 1954, in the coastal and tidal areas extending south to South Carolina, and in view of the damages caused by other hurricanes in the past, the Secretary of the Army, in cooperation with the Secretary of Commerce and other Federal agencies concerned with hurricanes, is hereby authorized and directed to 
cause an examination and survey to be made of the eastern and southern seaboard of the United States with respect to hurricanes, with particular reference to areas where severe damages have occurred.

SEC. 2. Such survey, to be made under the direction of the Chief of Engineers, shall include the securing of data on the behavior and frequency of hurricanes, and the determination of methods of forecasting their paths and improving warning services, and of possible means of preventing loss of human lives and damages to property, with due consideration of the economics of proposed breakwaters, seawalls, dikes, and, and other structures, warning services, or other measures which might be required.

To collect data on the water levels and damage caused by Hurricane Carol, the Corps conducted a major door-to-door survey of thousands of homes, industries, and other affected properties in 1955 and 1956 (Wiegel 1993). They then estimated the extent of damage that could be expected to property and machinery at several project sites for various levels of flooding and prepared water stage - damage curves. The result was a series of interim studies for vulnerable coastal towns throughout southern New England and for areas along the south Atlantic Coast and the Gulf of Mexico. These studies summarized storm conditions experienced in the towns, proposed a hurricane protection plan, and estimated the damages that might be avoided if a barrier were in place when a standard project hurricane struck the area. McAleer and Townsend (1958) summarized the findings and plans, and Appendix C is a bibliography of New England reports.

One of the New England Division's most ambitious proposals was to build barriers across the mouth of Narragansett Bay to prevent a surge (Figure 7). The dikes across West Passage and East Passage were to have ungated openings large enough to allow ships to pass, but small enough to limit the quantity of water entering the bay during a hurricane. The Narragansett Bay studies were conducted over a 9-year period and involved the New England Division, U.S. Army Engineer Coastal Engineering Research Center, U.S. Army Engineer Waterways Experiment Station, U.S. Weather Bureau, Coast \& Geodetic Survey, Public Health Service, Fish \& Wildlife Service, and several universities, including Texas A\&M, the University of Rhode Island, and the Massachusetts Institute of 
Technology (MIT) (McAleer 1963). The U.S. Army Engineer Waterways Experiment Station built a hangar-size physical model of the bay at 1:1000 horizontal and 1:100 vertical scale in 1956 and tested flushing, salinity, hydraulic, and navigation conditions (New England Division 1963; Pickering and Grace 1965; Simmons 1964; U.S. Army Engineer Waterways Experiment Station 1959a, b). The modelers examined discharge characteristics of the navigation opening (with a base width of 1,500 ft) for East Passage. MIT researchers examined hydrodynamic and wave conditions at proposed barriers (McLaughlin and Anton 1964). A more detailed model of East Passage at a 1:150 undistorted scale was built at the request of the U.S. Navy to test fleet operations under various wave and tide conditions (Housley 1967). The final plan estimated that the Narragansett barriers would prevent more than 90 percent of the design flood damages of \$126 million in the area below the Fox Point barrier and that the construction would cost about $\$ 90$ million.

The Corps of Engineers recognized the potential for environmental disruption and sponsored a series of studies on salinity, fisheries, pollution (Public Health Service 1960), and tidal circulation (Hicks 1956). For example, the physical model in Vicksburg, MS, was of impressive scale and was operated for more than 4 years. University of Rhode Island fisheries experts studied fish populations and concluded the barriers would not disrupt spawning or feeding (Saila 1962).

Despite a decade of intensive study, the Narragansett Bay barriers were never built. This author was unable to find documents stating the final reason why the project never came to fruition, but the high cost of stone construction in deep water almost surely rendered the project uneconomical. ${ }^{1}$ In this same era, NED had been studying the feasibility of building massive stone structures across Passamaquaddy Bay, ME, for the Passamaquaddy Tidal Power Project, and placing stone in deep water raised too many engineering and fiscal challenges (Parkman 1978). Politics and environmental concerns also played a role in stopping the Narragansett Bay project, as they did to a similarly-ambitious Galveston Bay surge barrier. ${ }^{2}$ But ultimately, construction never began because wealthy and politically well-connected yachtsmen were concerned that

\footnotetext{
${ }^{1}$ Mr. R. J. DiBuono, Headquarters, U.S. Army Corps of Engineers, retired, personal communication, 27 November 2006.

2 Mr. Richard Sager, Hydraulics Laboratory, U.S. Army Engineer Waterways Experiment Station, retired, personal communication, 13 February 2007.
} 
they would not be able to sail or motor their yachts through the openings because of strong currents.

Finally, from among 14 flood protection plans proposed for New England, five were authorized and funded:

1. Fox Point, Providence, RI - barrier, navigation gates, and pumps.

2. New Bedford, MA - barrier, navigation gates, and pumps.

3. New London, CT - barrier and navigation gate.

4. Pawcatuck, CT - earthfill and concrete walls.

5. Stamford, CT - barrier and pump station.

It is unclear why Mystic, Fairfield, Point J udith, Narragansett Pier, and other sites were rejected, but possibly the benefit-cost ratios did not exceed 1.0. In some cases, the local partners were unable to generate their share of the construction funds.

Another project with levees, beach fill, and a pumping station was authorized for Raritan and Sandy Hook Bays, NJ . Finally, in the early 1970s, another project was added to the group, a dam with pumps at the mouth of the Charles River in Boston.

In the early 1960s, the requirements for environmental permits and investigations prior to construction of major works were much less stringent than they are now. The USACE did coordinate with other agencies, but often the approval letter was little more than a single page included in the interim report and the general design memorandum. In New Bedford, cleanup of a superfund site and brownfields area in the upper harbor began in the 1970s, a decade after construction of the barrier. It is unclear if the presence of contaminated sediments in the harbor was factored into the design. By the time the Charles River project was conceived and built, requirements had changed, and much more extensive environmental studies were conducted. 


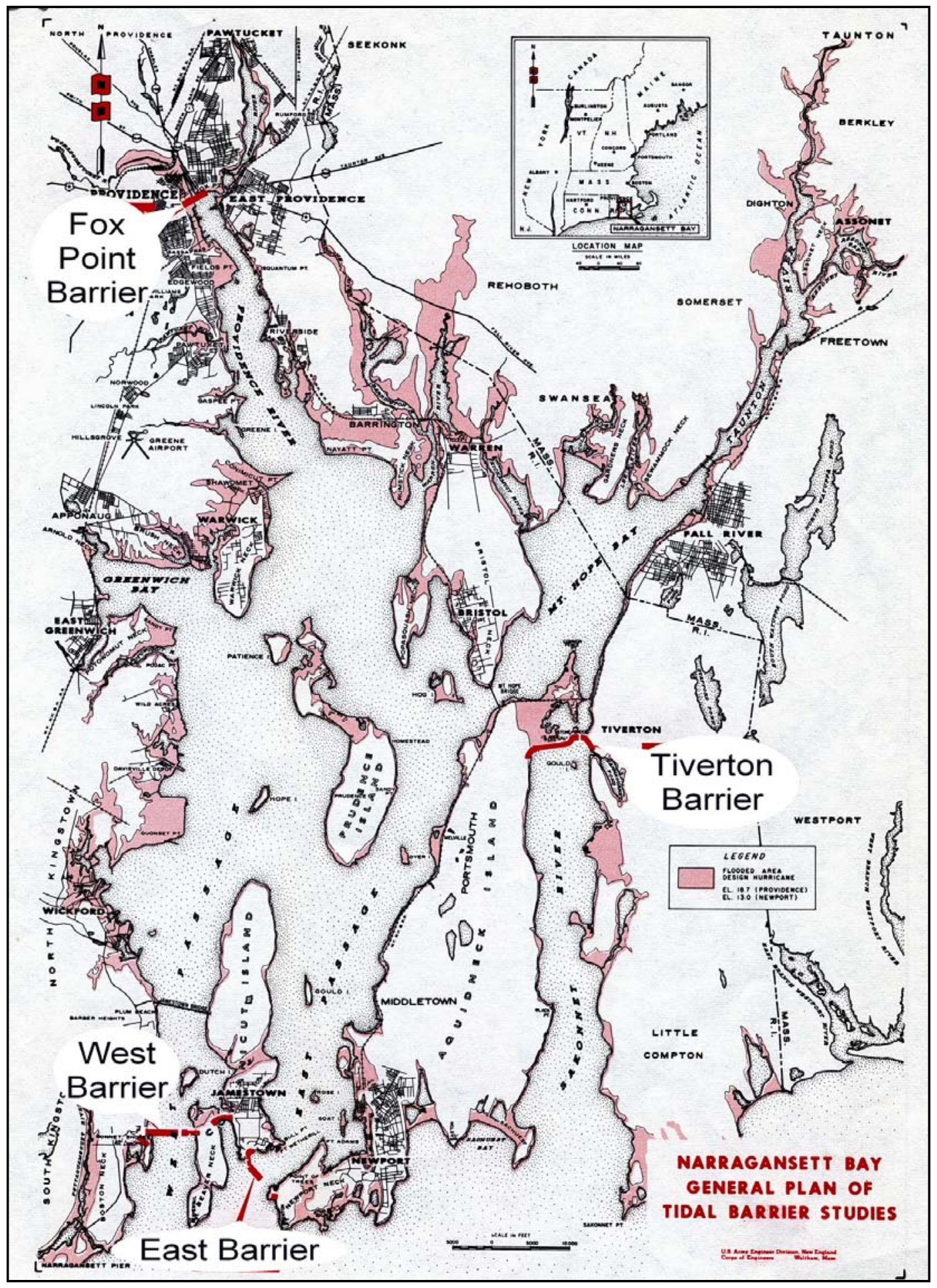

Figure 7. Proposed hurricane barriers in Narragansett Bay, RI (map from New England Division 1963). 


\section{Fox Point Barrier, Providence, RI}

\section{Project description}

The Fox Point Hurricane Barrier was the first structure of its type in the United States to be approved for construction (Figures 8, 9, and 10). The following description is from the New England District web page: ${ }^{1}$

The Fox Point Hurricane Protection Barrier in Providence is located immediately south of the Narragansett Electric Company plant, about 0.2 miles north of Fox Point and one mile south of downtown Providence.

The project provides virtually complete protection against tidal flooding from hurricanes and other coastal storms to about 280 acres of downtown Providence. The protected area includes the commercial and industrial center, transportation facilities, public utilities, and many homes. The city suffered extensive damage from the hurricane of 1938 and Hurricane Carol in 1954 when, in each instance, water depths of up to $8 \mathrm{ft}$ were experienced in the city's commercial area. Damage from the 1938 hurricane amounted to \$16.3 million -- and damage from Hurricane Carol amounted to $\$ 25.1$ million. Construction began in J uly 1961 and was completed in J anuary 1966, at a cost of $\$ 15$ million. The city of Providence operates and maintains the project.

The barrier itself is a 700-ft-long concrete structure, $25 \mathrm{ft}$ high, that extends westerly across the Providence River from Tockwotton Street, near Fox Point, to Globe Street, near the power plant. The structure contains three tainter gate openings that prevent the entry of floodwaters from the bay when closed and permit passage of small vessels when open. Each gate is $40 \mathrm{ft}$ high and $40 \mathrm{ft}$ wide.

\footnotetext{
1 From the New England District Water Resources web page: http://www.nae.usace.army.mil/ water/topic.asp?mytopic=foxpoint, 13 November 2006.
} 
Two 10 to 15-ft-high earthfill dikes with stone slope protection, flank each side of the barrier. The eastern dike is $780 \mathrm{ft}$ long and the western dike is $1,400 \mathrm{ft}$ long.

A pumping station and cooling water canal are integral parts of the project. During a tidal/ flood situation, the pumping station's five large pumps can discharge the floodwaters of the Providence River through the barrier into the bay. Two gated openings in the pumping station, each $10 \mathrm{ft}$ high and $15 \mathrm{ft}$ wide, admit water into the cooling water canal used by the Narragansett Electric Company, located immediately behind the barrier.

There are three vehicular gates located at Allens Avenue, South Main Street, and the Narragansett Electric Company and five sewer gates that prevent high tides from backing up through the sewer lines.

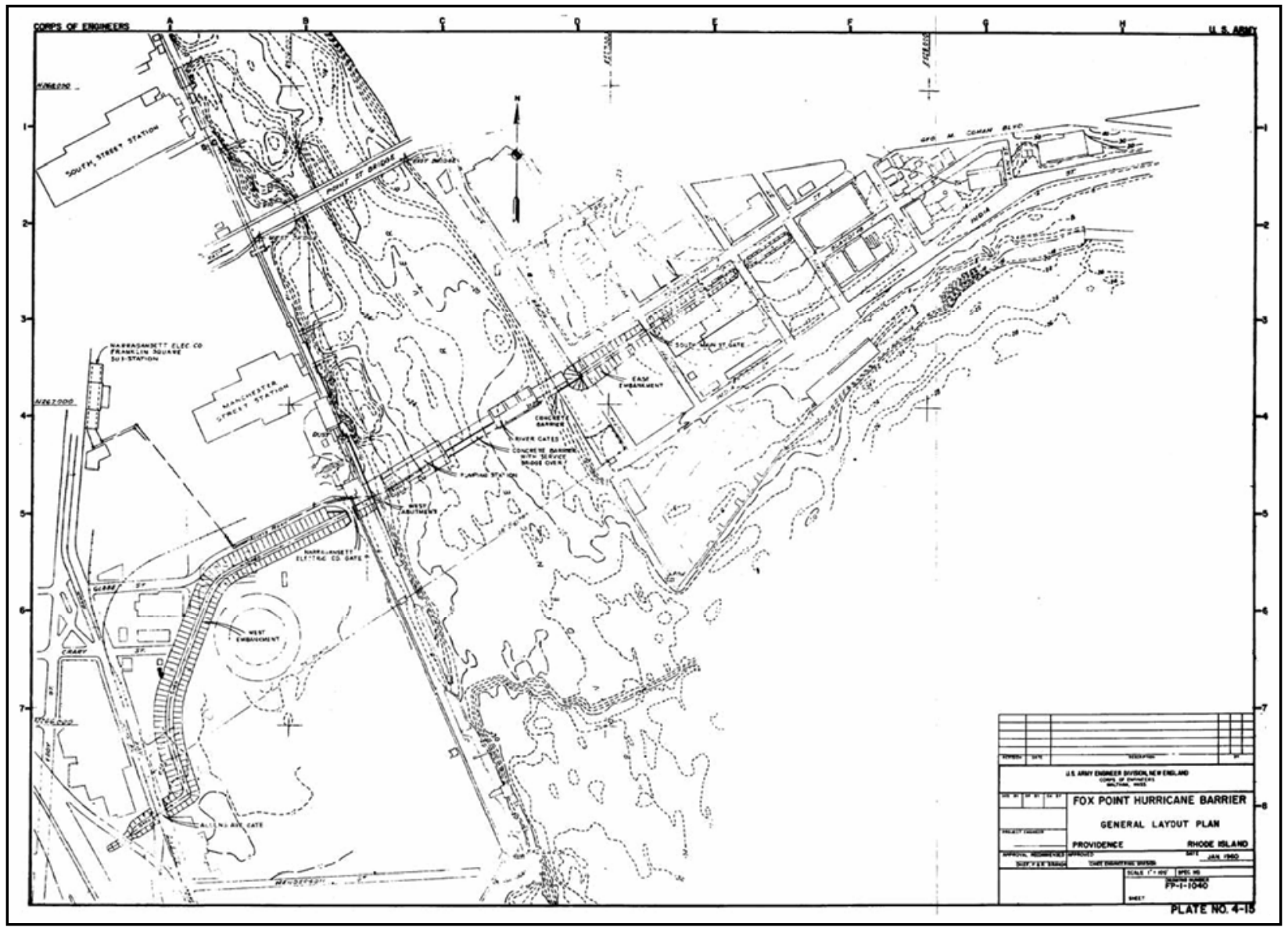

Figure 8. Fox Point project elements, from General Design Memorandum No. 4, January 1960. 


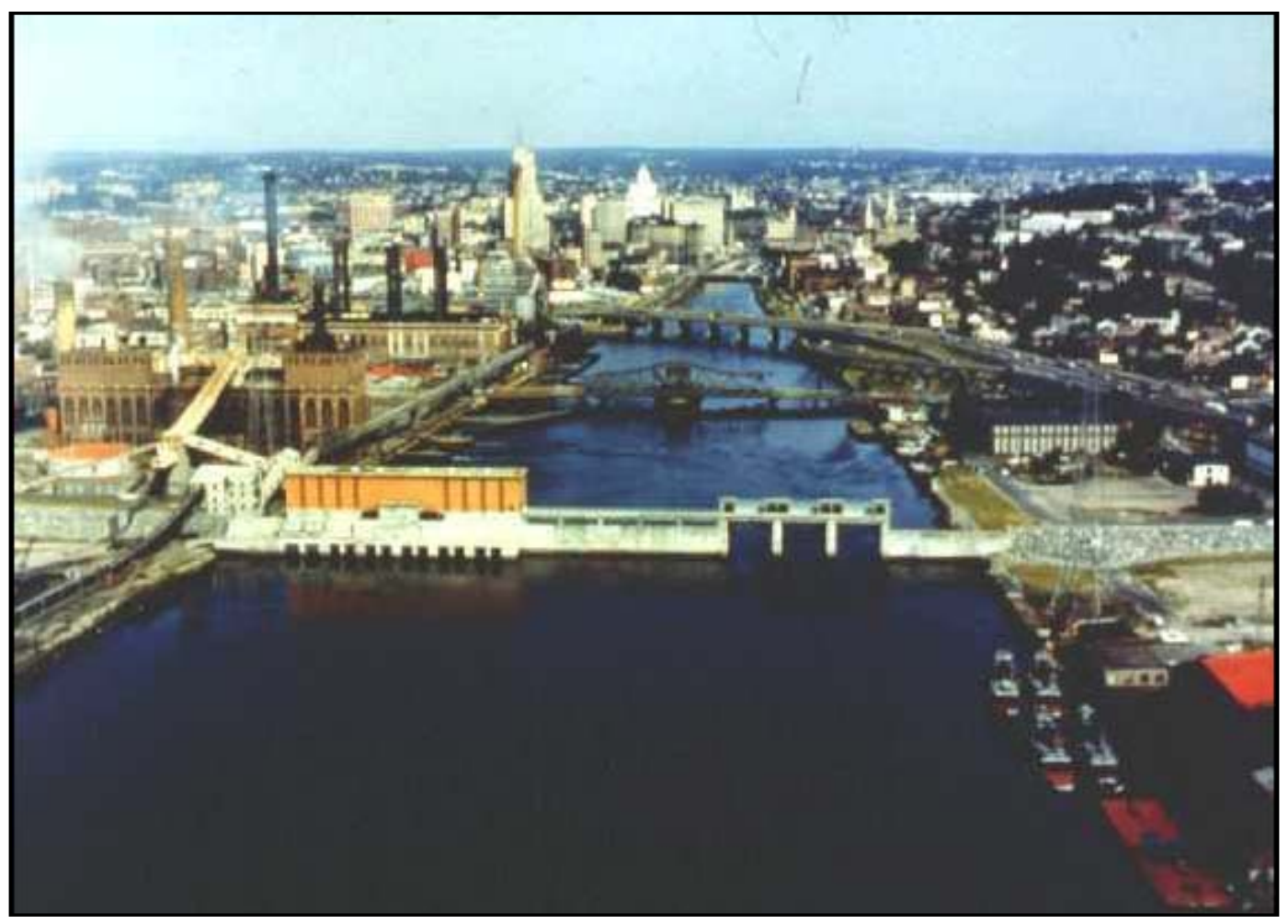

Figure 9. Fox Point hurricane barrier, view looking north toward downtown Providence. 2005 photograph predates the new l-195 bridge.

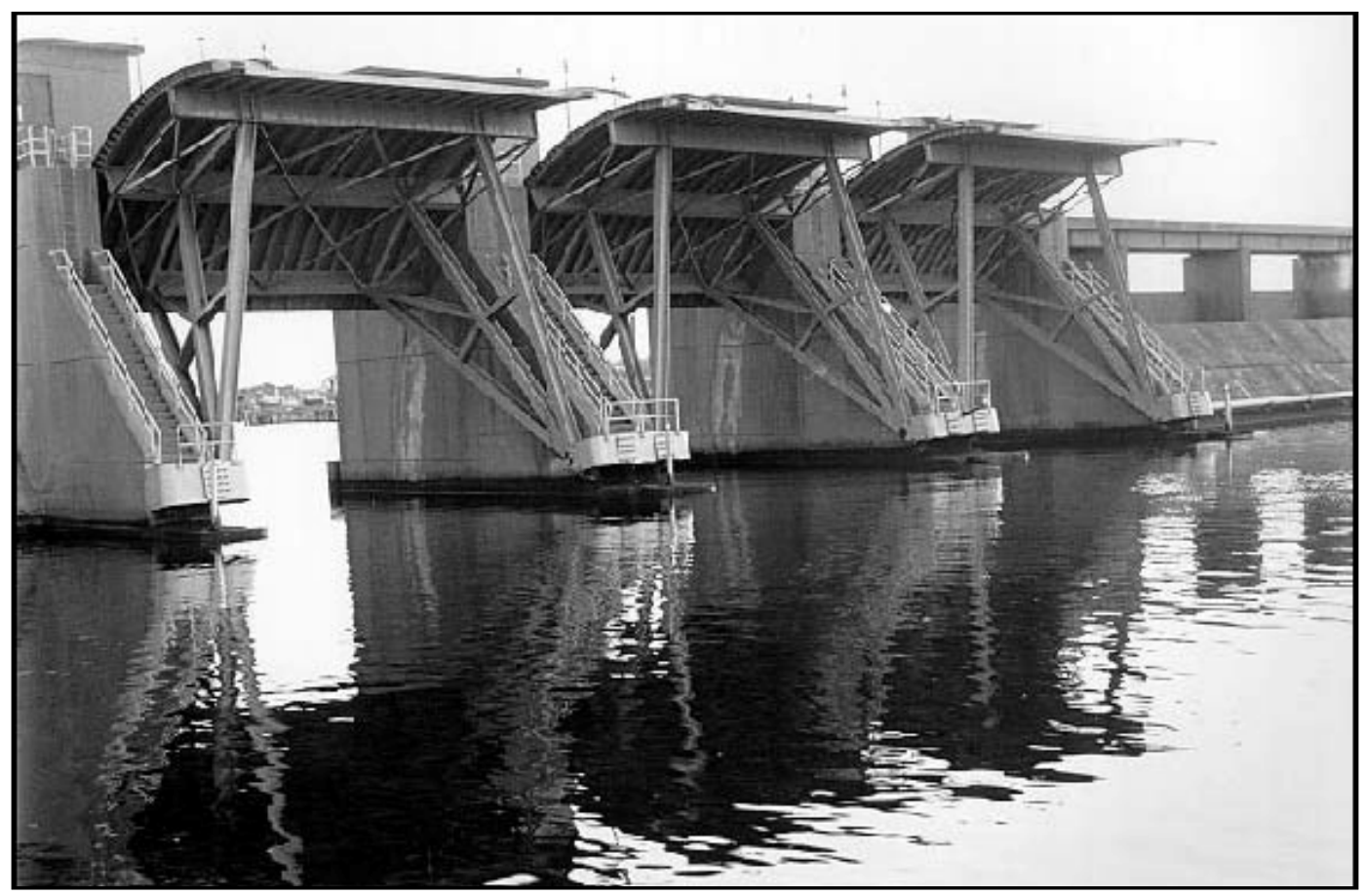

Figure 10. View of Providence River (north) side of barrier with gates up (undated photograph from City of Providence). 


\section{Design and details}

The following design summary is from the New England District web page: 1

The Design Hurricane was established through cooperation with the U.S. Weather Bureau and the Beach Erosion Board affiliated with the Texas Research Foundation of Texas A\&M University. The basis for the design storm was the transformation of the September 1944 hurricane. This storm, when it was off the Cape Hatteras, NC, coast, had the greatest energy of any known hurricane along the Atlantic coast. The 1944 storm was transposed so that it would be entirely over water between Cape Hatteras and the New England coast, resulting in a central pressure of $27.71 \mathrm{in.}$ mercury near the mouth of Narragansett Bay. The transposed storm was moved northerly with a forward speed of about 40 knots along a critical track moving northerly and producing sustained winds of $90 \mathrm{mph}$ from the SSE at the entrance to Narragansett Bay to Providence. Within Narragansett Bay, at the location of the Fox-Point barrier in Providence, a tide surge associated with this storm was computed to be $17.4 \mathrm{ft}$. This surge was added to the mean spring high water elevation of 3.1ft-NGVD [National Geodetic Vertical Datum], resulting in a $20.5 \mathrm{ft}-\mathrm{NGVD}$ stillwater elevation. The top of the barrier was set to $25.0 \mathrm{ft}-\mathrm{NGVD}$ allowing for wave overtopping in excess of $4.5 \mathrm{ft}$. A $20.5 \mathrm{ft}-\mathrm{NGVD}$ design stillwater elevation is approximately a 500-year tide level.

Project features:

- Design Hurricane Tide =20.5 ft NGVD.

- $700 \mathrm{ft}$ long Concrete Barrier across Providence River.

- 2,200 ft long Earth-filled Dikes to high ground at east/ west ends.

- Top Elevation $=25.0 \mathrm{ft}$ NGVD.

- 3 River Tainter Gates $40 \mathrm{ft}$ x $40 \mathrm{ft}$ (invert elev. =-15.0 ft NGVD).

- River Pump Station - 7,000 cfs capacity (5 pumps @ 1,400 cfs each).

\footnotetext{
1 From NAE web page: https://rsgis.crrel.usace.army.mil/nae/pls/nae/nae_web.nae_webmenu. displaymenu?menu=main, 1 December 2006.
} 
- Standard Project Flood $=24,000$ cfs (DA [drainage area $]=$ 77 square miles).

- 3 Steel Swing Vehicle Gates:

* Allens Avenue $=70 \mathrm{ft}$ wide $\mathrm{x} 13 \mathrm{ft}$ high.

* Narragansett Electric Co. $=15 \mathrm{ft}$ widex $15 \mathrm{ft}$ high.

* South Main Street $=40 \mathrm{ft}$ widex $11 \mathrm{ft}$ high.

Table 1 summarizes hydraulic conditions at this site, and Figures 11, 12, and 13 (from the General Design Memorandum), show hurricane elevation curves. Figure 14 is the elevation-frequency curve based on 320 years of record.

Table 1. Water elevations, Fox Point hurricane barrier, Providence, RI.

\begin{tabular}{|l|l|l|}
\hline \multicolumn{3}{|c|}{ Mean Tide Data } \\
\hline Stage & Elev. (ft, NGVD) & \\
\hline Mean high water & 2.8 & \\
\hline Mean low water & -1.8 & \\
\hline Mean tide range & 4.6 & \\
\hline \multicolumn{3}{|c|}{ Water Levels } \\
\hline Date & Elev. (ft, NGVD) & Event \\
\hline \multicolumn{3}{|c|}{ Highest Since Project Construction } \\
\hline $08 / 1991$ & 8.6 & Hurricane Bob \\
\hline $01 / 1978$ & 8.4 & Coastal storm \\
\hline \multicolumn{3}{|l|}{ Highest Historical } \\
\hline $08 / 1638$ & $18 \pm$ & Hurricane \\
\hline $08 / 1635$ & $17 \pm$ & Hurricane \\
\hline $09 / 1938$ & 15.7 & Great New England Hurricane \\
\hline $08 / 1954$ & 14.7 & Hurricane Carol \\
\hline $09 / 1815$ & 14.2 & Hurricane \\
\hline $09 / 1944$ & 9.9 & Hurricane \\
\hline 11/1953 & 7.9 & Storm \\
\hline 11/1947 & 7.3 & Storm \\
\hline N0TE: Start of damage $=6.8 \mathrm{ft}$ NGVD. Data from the New England District web page, \\
7 December 2006, and General Design Memorandum, January 1960. \\
\hline
\end{tabular}




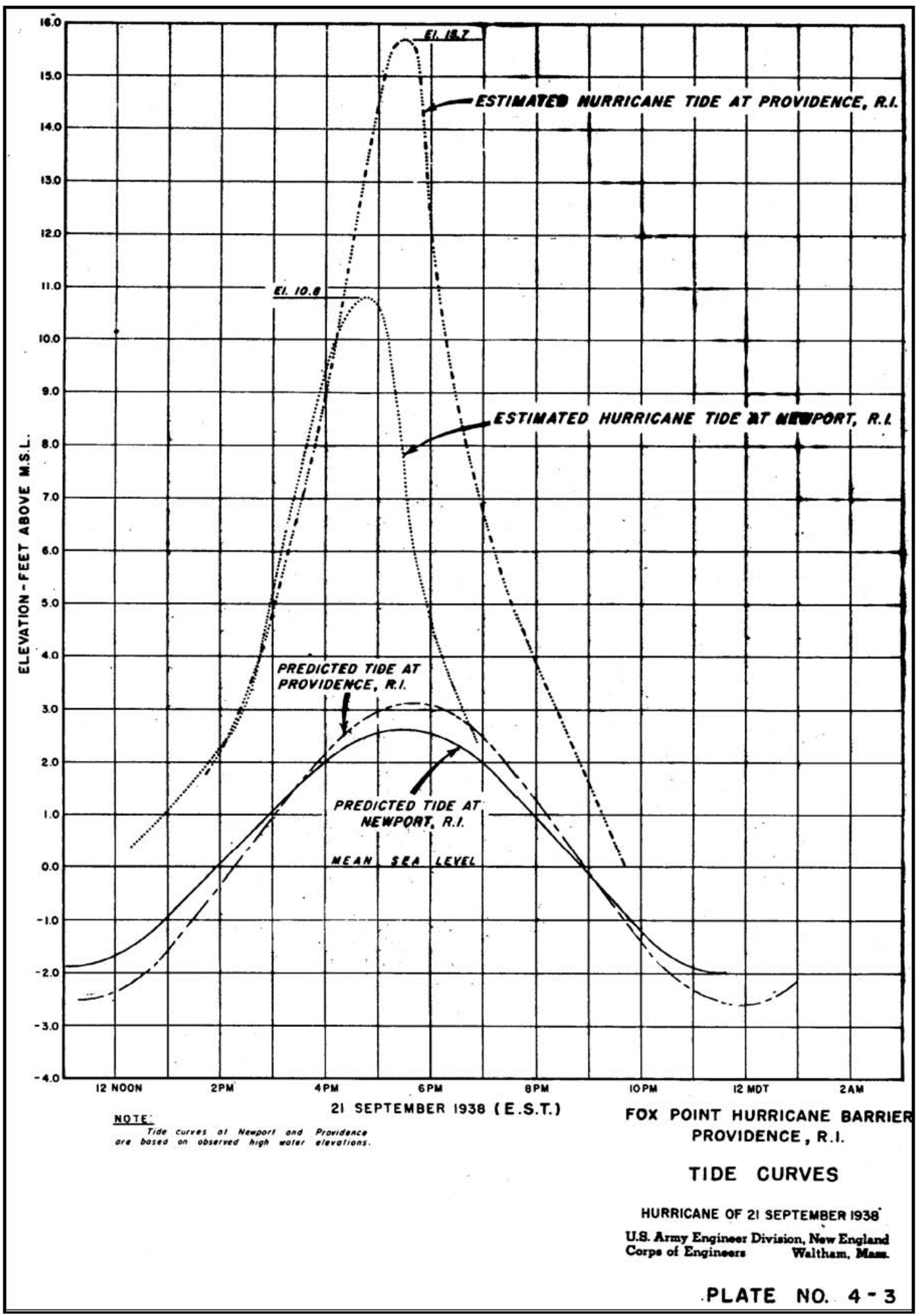

Figure 11. Water elevations for September 1938 hurricane at Providence and Newport. Peaks were at 15.7 and $10.8 \mathrm{ft}$. 


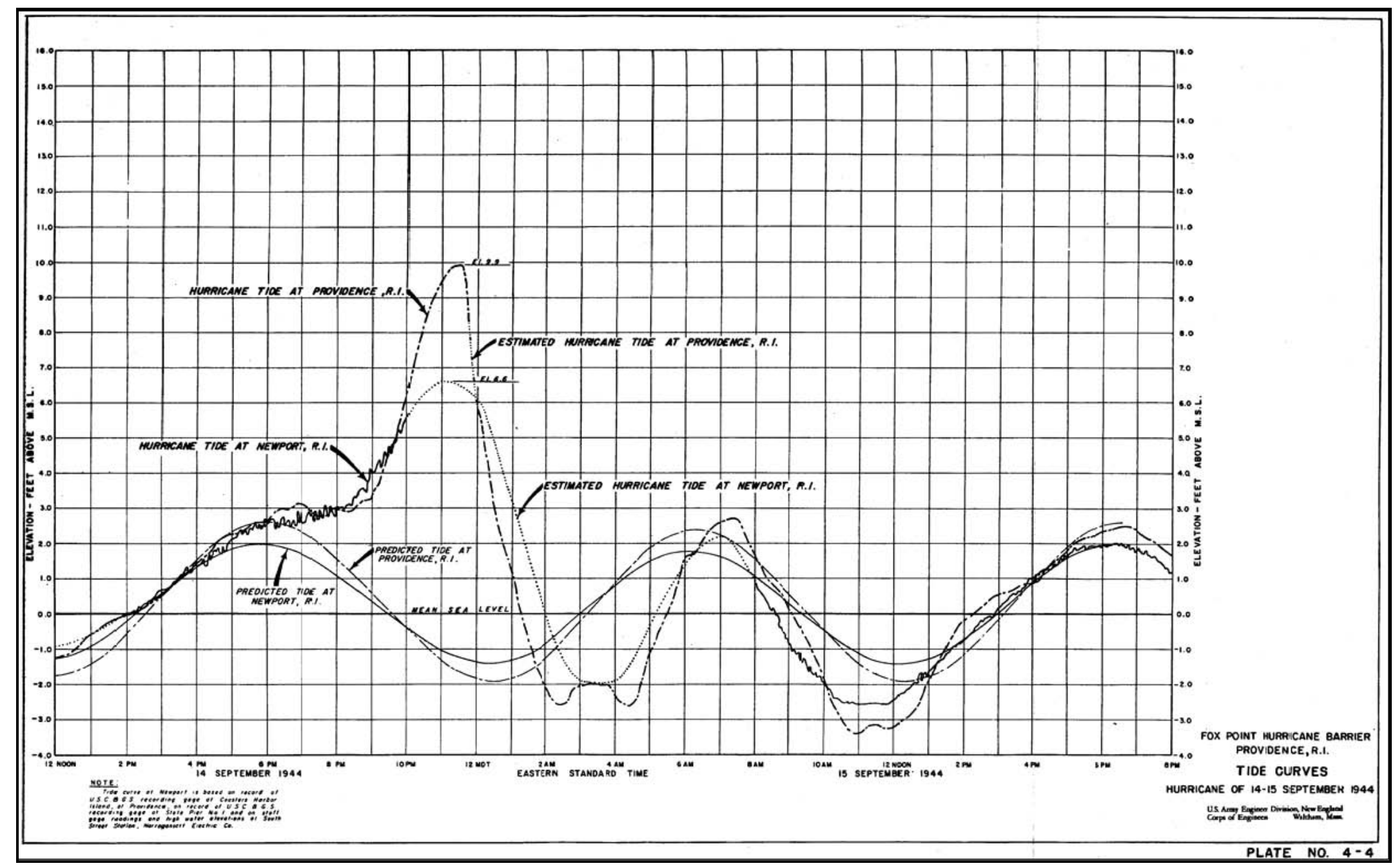

Figure 12. Water elevations for 1944 hurricane at Providence and Newport. Providence peak was $9.9 \mathrm{ft}$. 


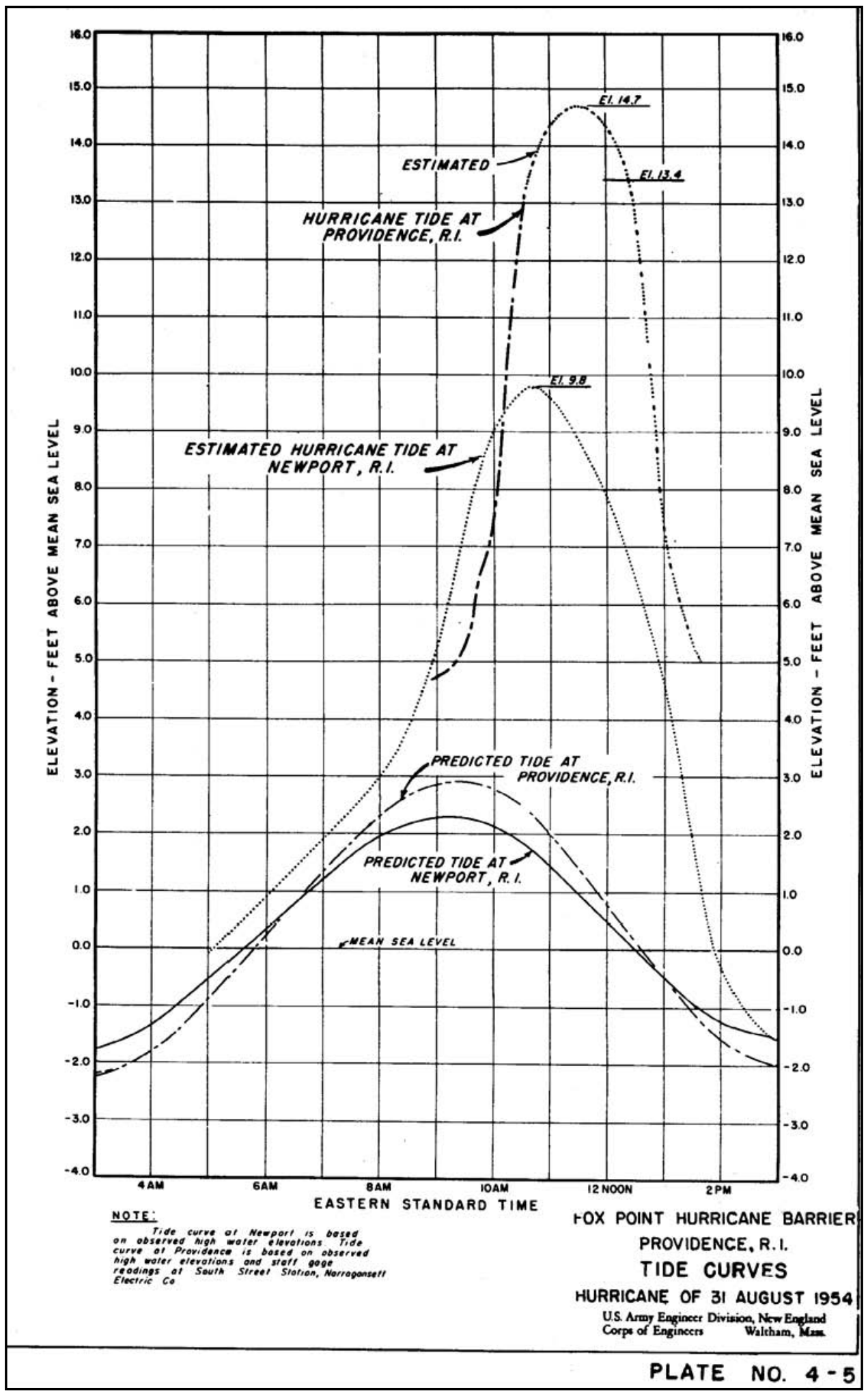

Figure 13. Water elevations for Hurricane Carol at Providence and Newport. Peaks were at 14.7 and $9.8 \mathrm{ft}$. 


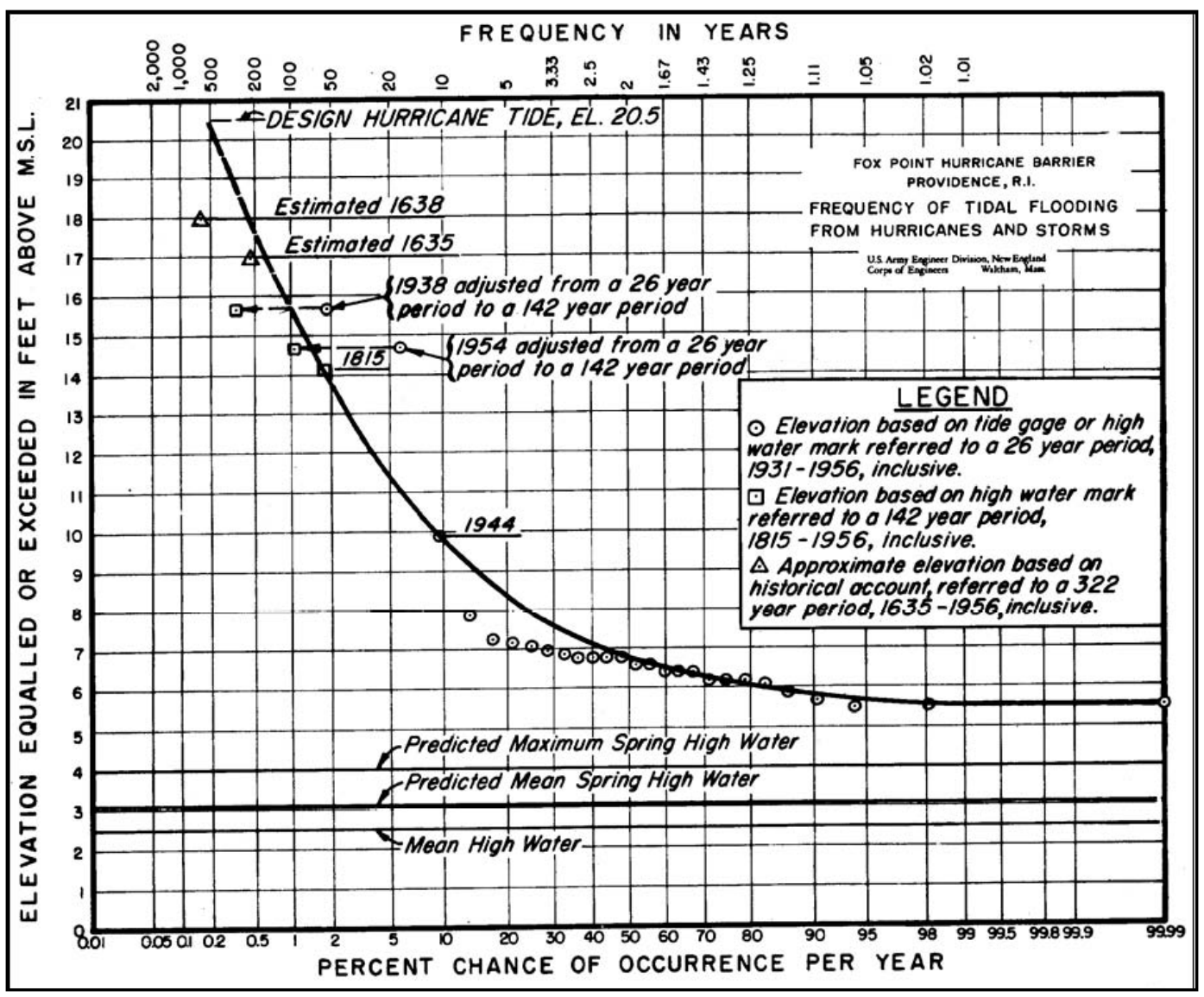

Figure 14. Providence elevation-frequency curve.

Total cost of the project was about \$15 million, with the Federal portion about \$11 million. Construction began in December 1960 and was completed in J anuary 1966 after delays caused by strikes and other supply problems.

The dike, pump house, and gate structure are supported on steel H-piles driven to bedrock. Bedrock consists of the Rhode Island Formation, a deformed and weakly metamorphosed sequence of Pennsylvanian conglomerate, sandstone, siltstone, shale, and graphitic shale and coal. A sheet pile cut-off wall was installed to block seepage beneath the structure and through surficial soils, therefore preventing erosion below the barrier. Construction was completed inside a series of circular sheet pile cofferdams. This allowed soft organic silts and fine sands to be excavated to elevation - $36 \mathrm{ft}$ and replaced with granular fill. The H-bearing piles and cutoff wall were driven downward from this granular surface (AEG 2006).

The pumping station, located near the west side of the river, is a reinforced concrete building $213 \mathrm{ft}$ long and $91 \mathrm{ft}$ wide and situated above the design 
storm height of $25 \mathrm{ft} \mathrm{NGVD.} \mathrm{The} \mathrm{five} \mathrm{pumps} \mathrm{were,} \mathrm{at} \mathrm{the} \mathrm{time} \mathrm{of}$ installation, the largest of their type ever built (Figures 15 and 16). At a height of about $55 \mathrm{ft}$ and diameter of $20 \mathrm{ft}$, they can transfer about $3.15 \mathrm{million} \mathrm{gal} / \mathrm{min}$ from the Providence River into Narragansett Bay. The pumps receive electricity from the Narragansett Electric Company at 11,000 volts. There is no provision for on-site emergency generators.

Since construction, this project has never been tested with a flood anywhere near its design height. On 19 August 1991, Hurricane Bob's water elevation was $8.6 \mathrm{ft}$, over $7 \mathrm{ft}$ below the 1938 surge. The pumps have been used at least 12 times since 1966, and the barrier has proven its worth during at least two hurricanes, once by preventing a 2-ft inundation from Hurricane Gloria in September 1985, and the second by preventing a 4-ft flood from Hurricane Bob in August 1991.

It is difficult to know the value of infrastructure and business now protected by the Fox Point barrier. Senator J ack Reed's web page claims that the structure "protects tens of thousands of people and approximately $\$ 5$ billion worth of property." 1 Senator Lincoln Chaffee states, "Today, it protects an estimated $\$ 2$ billion worth of infrastructure, including homes, businesses, and the seats of city, state and Federal government in downtown Providence."2 Experience from the 2004 hurricane season in Florida and from Hurricanes Katrina and Rita in 2005 proves that any large-scale flooding and wind event now causes billions of dollars in damage.

\footnotetext{
1 From Senator Reed's web page: http://www.senate.gov/ reed/newsroom/details.cfm?id=256878, 8 December 2006.

2 From Senator Chaffee's web page: $h$ ttp://chafee.senate.gov/public/index.cfm?FuseAction= PressReleases.Detail\&PressRelease_id=359\&Mont $h=5 \&$ Year=2006, 8 December 2006.
} 


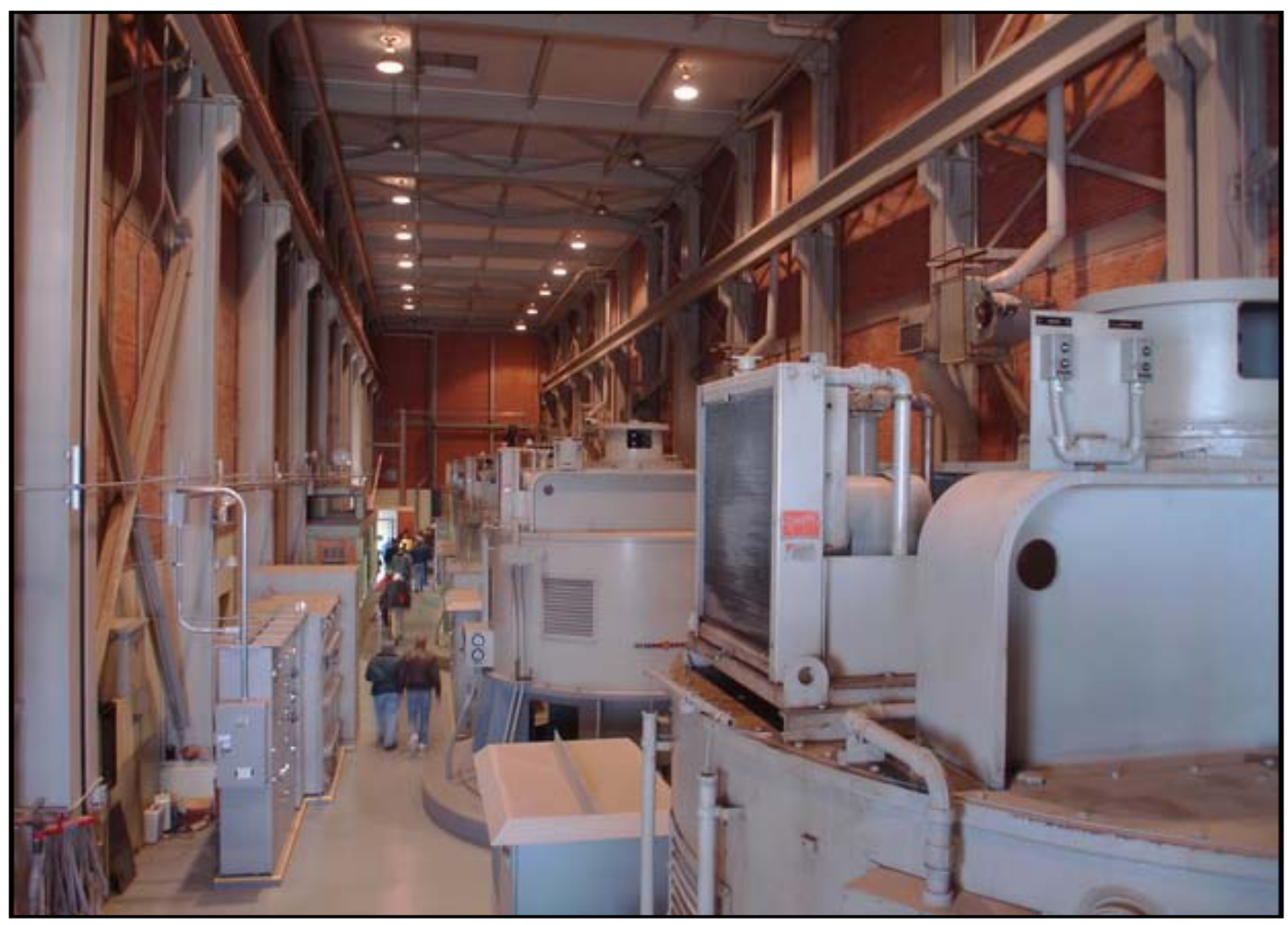

Figure 15. Fox Point pump house, 4 November 2006.

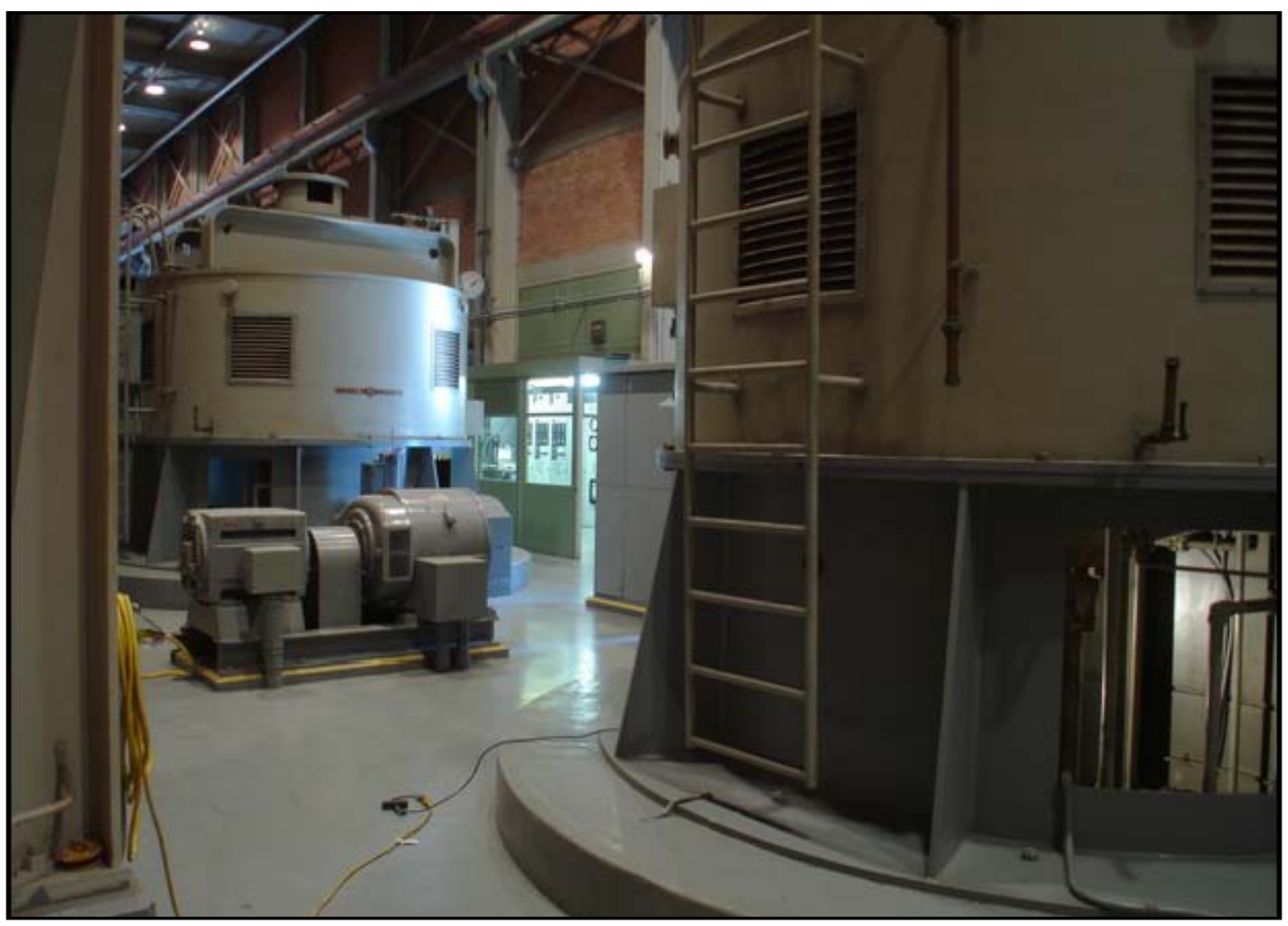

Figure 16. Pumps at Fox Point barrier, 4 November 2006. 


\section{Operation}

The hurricane barrier and all the equipment are owned and operated by the City of Providence, RI, but the pumps and gates will revert to the USACE in 2008 (details discussed below). The city and the New England District each conduct inspections twice a year, resulting in the equipment being operated at least four times annually.

When a hurricane reaches the 38-deg latitude and a hurricane watch is initiated, city work crews assemble and close the vehicular gates. Once a storm enters Narragansett Bay, the flood gates are closed to prevent a surge from entering the business district of the city. It takes about $30 \mathrm{~min}$ to lower the gates and $2 \mathrm{hr}$ to raise them. The pumps have been operated about 12 times since 1966 (AEG 2006).

During a site visit on 4 November 2006, City of Providence engineers reported that the plant and equipment were in good mechanical condition, and the pumps were recently overhauled. The electrical controls are original and need to be upgraded. The controls use electromechanical relays, and parts are increasingly difficult to replace (Figure 17). They reported that if electricity were interrupted in an emergency, the tide gates could be lowered by hand by manually releasing brakes. However, it would be impossible to raise the gates without electricity for the motors, and, of course, the pumps would not function to push Providence River water out to Narragansett Bay.

The new I-195 bridge has just been erected immediately south of the hurricane barrier. Part of the dike east of the river has been incorporated into the freeway ramps (Figure 18). The bridge had to be situated close to the barrier because of sewers and other conduits that cross under the Providence River further south. As a result, the pile foundation had to be carefully designed to avoid interfering with the H-piles of the hurricane barrier. 


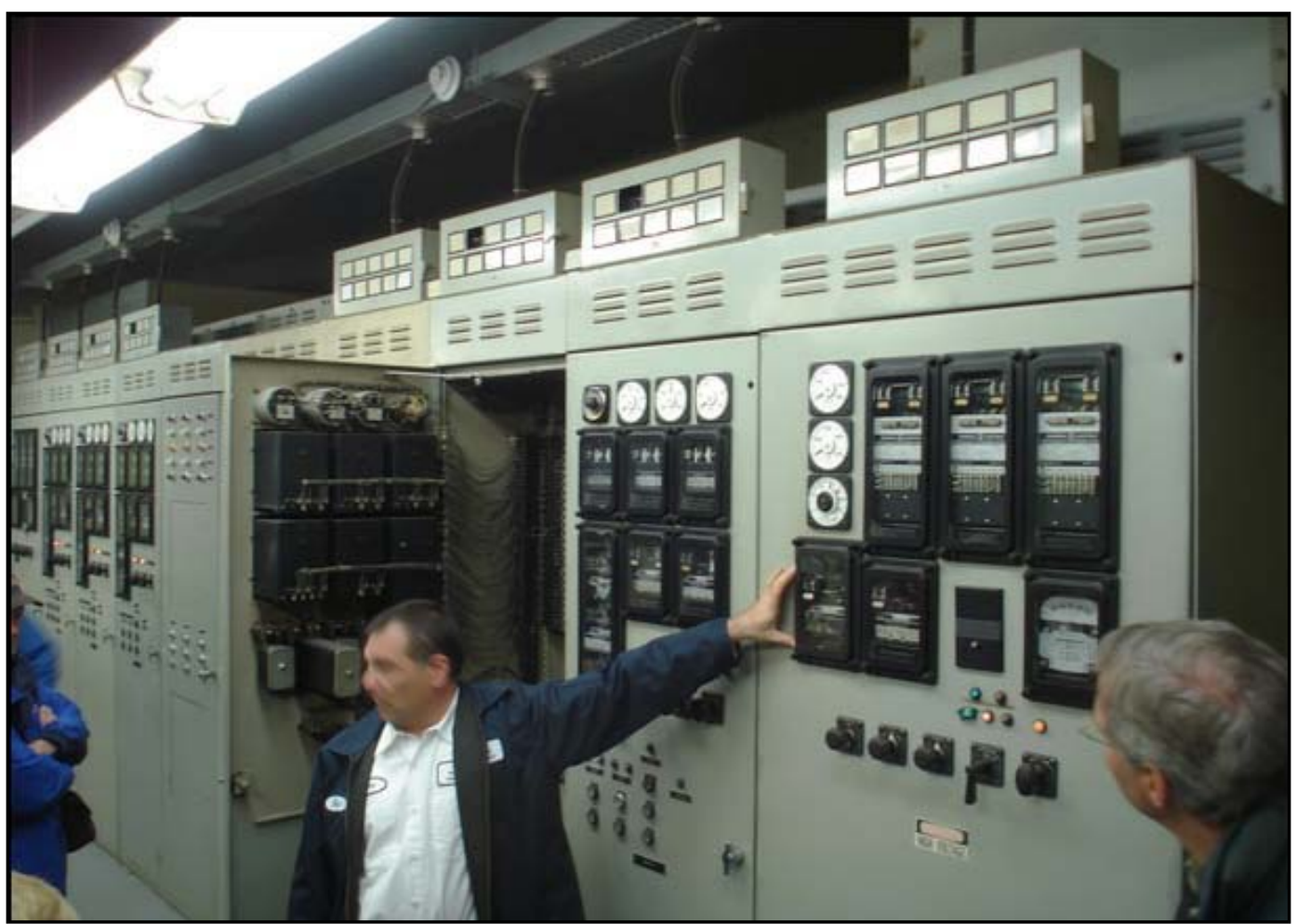

Figure 17. Controls for pumps and equipment, Fox Point pump house, 4 November 2006. Engineers are City of Providence employees.

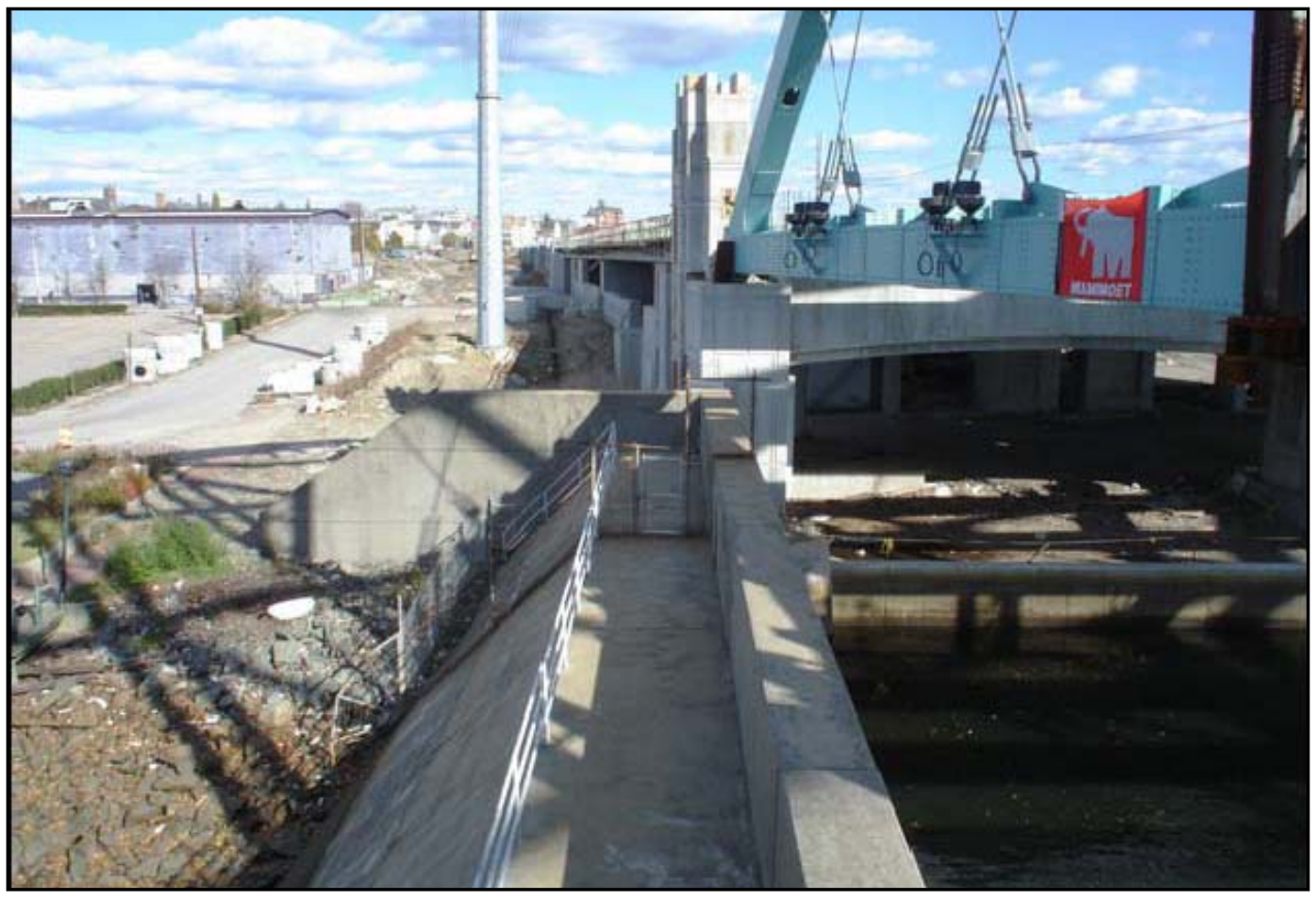

Figure 18. View east from Fox Point hurricane barrier showing ramps and newly-built l-195 bridge, 4 November 2006 . Concrete freeway ramps substitute for some of original dike. 


\section{Project rehabilitation}

A technical assessment conducted by the New England District in 1998 found that the project had been operated infrequently during its 38-year life and that the station equipment had low hours of operation. Therefore, much of its original design life remained, but some maintenance had been deferred and needed to be addressed. ${ }^{1}$ Section 352 of the 1999 Water Resources Development Act (WRDA) authorized the Fox Point Hurricane Barrier Repair project. Since then, the USACE overhauled the pumps and completed other work, but did not rehabilitate the electromechanical controls. ${ }^{2}$ The controls are getting increasingly unreliable, and the pumps are difficult to start. In December 2006, one of the pumps sustained serious internal damage while being tested and will be out of commission indefinitely. ${ }^{3}$ The motor and shaft turn, but the impeller below does not rotate. If there is significant damage, parts have to be custom built, and the impellers cost about $\$ 400,000$ each. The older impellers are becoming brittle and have displayed micro-fissures.

In April 2006, Mayor Cicilline of Providence testified there was an urgent need to transfer responsibility for the annual operation and maintenance from the City of Providence back to USACE to ensure the barrier is properly maintained. In May 2006, U.S. Senator Lincoln Chafee spearheaded language in the Senate version of the Supplemental Appropriations Bill (H.R. 4939) to provide authority for USACE to operate and maintain the Fox Point Hurricane Barrier. The USACE is scheduled to assume ownership of the pump equipment and navigation gates on 1 October 2008 . The City will continue to be responsible for the dikes on land and the sewer gates.

\section{Environmental factors}

Based on discussions with the New England District personnel, there have been no post-construction studies to assess whether the barrier has influenced circulation, sedimentation, or environmental conditions. Extensive geotechnical studies were recently conduced in the vicinity by other organizations for the I-195 bridge project and the Providence combined sewer overflow project, but these studies were not related to the barrier operation or maintenance.

\footnotetext{
1 Fact sheet, Fox Point Hurricane Repair Project, Providence, RI, March 2002, New England District. http://www.nae.usace.army.mil/projects/ri/fphbr/FoxPoint3-02.pdf, 1 December 2006.

2 Mr. Thomas Rosato, New England District, personal communication, 7 February 2007.

3 Mr. James Law, New England District, personal communication, 15 December 2006.
} 


\section{New Bedford Hurricane Barrier, New Bedford, MA}

\section{Project description}

Figure 19 and 20 show the site, and the following project description is from the New England District web page: ${ }^{1}$

The New Bedford Hurricane Protection Barrier lies across New Bedford and Fairhaven Harbor. It is approximately 50 miles south of Boston. The project protects about 1,400 acres in New Bedford, Fairhaven, and Acushnet from tidal flooding associated with hurricanes and coastal storms. This acreage is thickly settled with industrial and commercial properties, particularly along the waterfront and the shores of the Acushnet River. The area represents about 80 percent of land flooded in the September 1938 and August 1954 hurricanes, the latter storm causing \$8.3 million in flood damages.

Construction of the New Bedford Hurricane Protection Barrier began in October 1962 and was completed in J anuary 1966, costing \$18.6 million. The project required the relocation of power cables, modification of sewerage and drainage facilities, and acquisition of a small boat yard, several buildings, and about 36 acres of land. The city maintains the project, with the exception of the navigation gates and the barrier extending across New Bedford and Fairhaven Harbor which are operated and maintained by the Corps. The project is divided into three principal features: a barrier extending across New Bedford and Fairhaven Harbor with an extension dike on the mainland; Clarks Cove Dike in New Bedford; and Fairhaven Dike.

The barrier extending across the harbor consists of a 4,500-ft-long earthfill dike with stone slope protection. The barrier has a maximum elevation of $20 \mathrm{ft}$ and a $150-\mathrm{ft}$-wide gated opening to accommodate commercial and recreational navigation. It also has

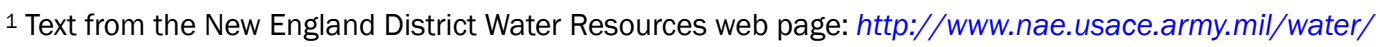
topic.asp?mytopic $=$ hpb-newbedford, 13 November 2006.
} 
two gated conduits that are each $9 \mathrm{ft}$ high and $6 \mathrm{ft}$ wide. The extension dike starts at the western end of the main dike and stretches for 4,600 ft along Rodney French Boulevard East. It has a maximum elevation of $22 \mathrm{ft}$. The extension dike has three circular gated conduits with diameters of 2, 3, and $4 \mathrm{ft}$, and a street gate on Rodney French Boulevard East.

Clarks Cove Dike consists of earthfill with stone slope protection. It is 5,800 ft long and extends around the north and east sides of the cove, tying to high ground at both ends. On the north side the dike has a maximum elevation of $22 \mathrm{ft}$, and on the east side the maximum elevation is $23 \mathrm{ft}$. The dike also has street gates at Rodney French Boulevard West and Cove Road, and a pumping station.

Fairhaven Dike consists of earthfill with stone slope protection. It starts at high ground near the foot of Lawton Street and runs easterly about 3,100 ft, with a maximum elevation of $20 \mathrm{ft}$. The dike also has a four-foot-diameter gated conduit. 


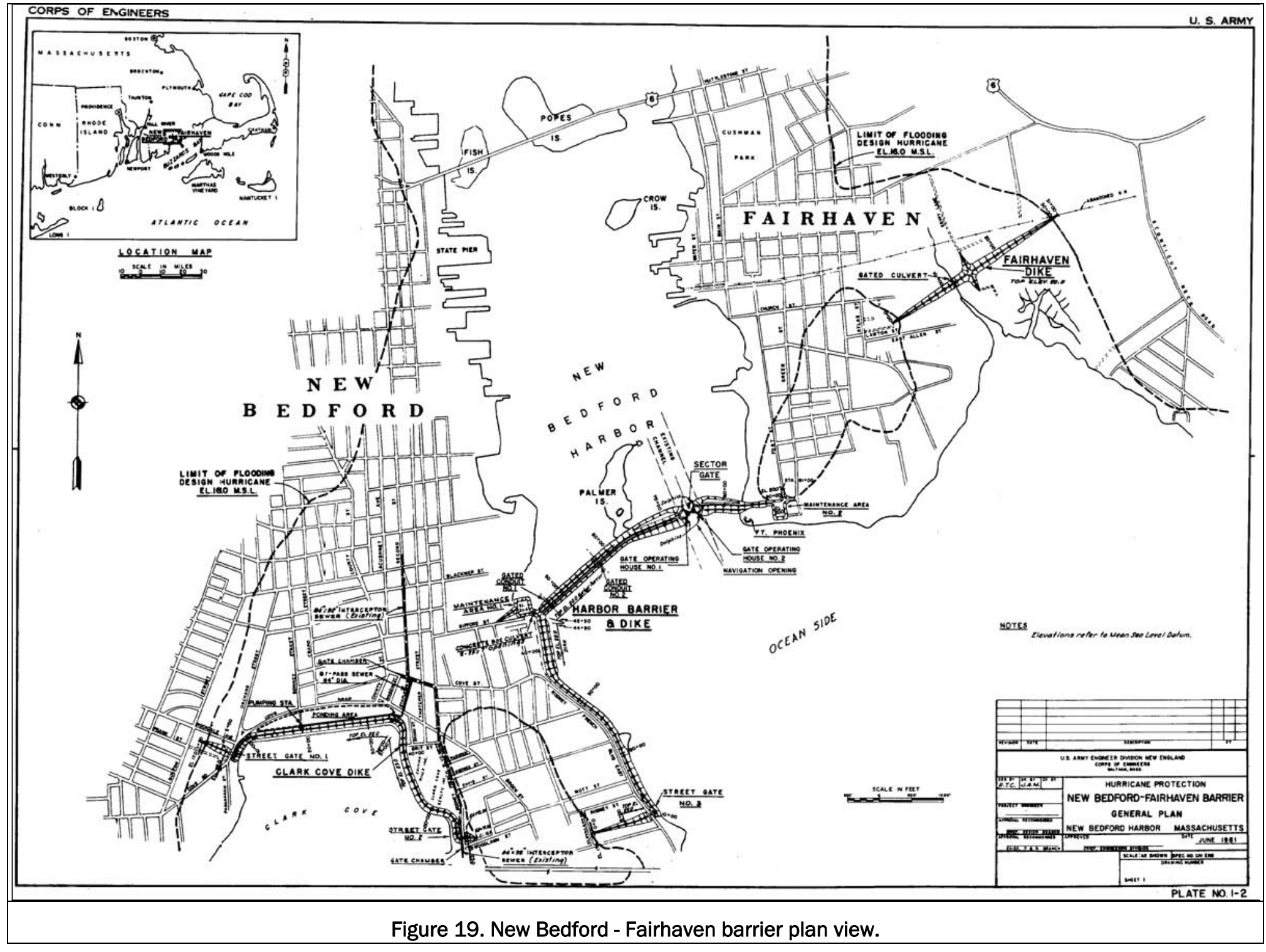




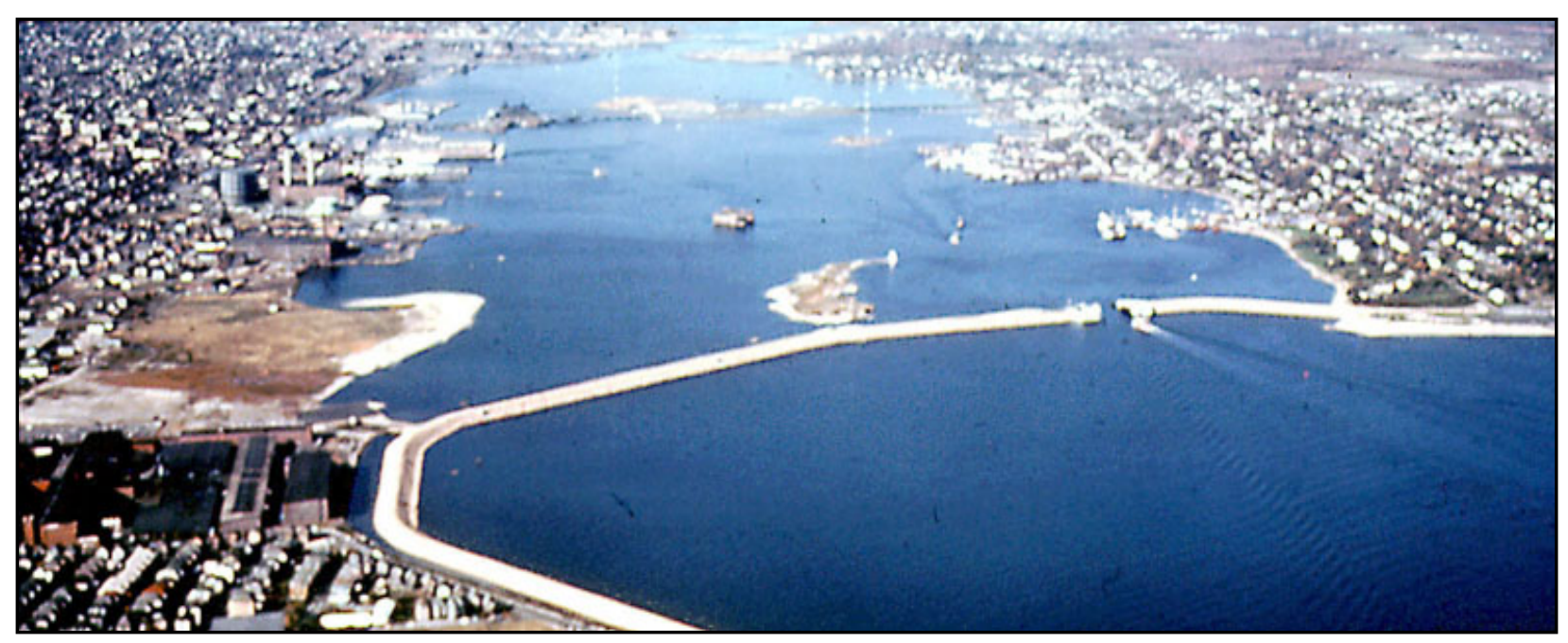

Figure 20. New Bedford dike and navigation gate.

\section{Design and details}

The following design summary is from the New England District web page. ${ }^{1}$ This is the same Design Hurricane used for the Fox Point project. Table 2 summarizes hydraulic conditions and Figures 21 and 22, from the General Design Memorandum, show the hurricane surge levels and the elevation-frequency curve.

The Design Hurricane was established through cooperation with the U.S. Weather Bureau and the Beach Erosion Board affiliated with the Texas Research Foundation of Texas A\&M University. The basis for the design storm was the transformation of the September 1944 hurricane. This storm, when it was off the Cape Hatteras, NC, coast, had the greatest energy of any known hurricane along the Atlantic coast. The 1944 storm was transposed so that it would be entirely over water between Cape Hatteras and the New England cost, resulting in a central pressure of 27.71 and 27.85 in. mercury near the mouth of Narragansett Bay, and New Bedford Harbor, respectively. The transposed storm was moved northerly with a forward speed of about 40 knots along a critical track creating sustained winds of $100 \mathrm{mph}$ from due south at New Bedford Harbor. Within New Bedford Harbor, a tide surge associated with this storm was computed to be $13.3 \mathrm{ft}$. This surge was added to the mean spring high water elevation of

\footnotetext{
1 From the New England District web page: https://rsgis.crrel.usace.army.mil/nae/pls/nae/ nae_web.nae_webmenu.displaymenu?menu=main, 1 December 2006.
} 
2.7ft-NGVD, resulting in a $16.0 \mathrm{ft}-\mathrm{NGVD}$ stillwater elevation. It was further determined that wave heights associated with this storm would be on the order of about $9.0 \mathrm{ft}$ for all south facing structures. The top of barrier elevation of the navigation gates was set to $20.0 \mathrm{ft}$-NGVD. A $16.0 \mathrm{ft}$-NGVD design stillwater elevation is slightly greater than a 500-year tide level. This design also includes coincident Standard Project Flood occurrence along the Acushnet River behind the barrier, which has a drainage area of 29.4 sq mi.

Project features:

- Design Hurricane Tide = $16.0 \mathrm{ft}$ NGVD.

- New Bedford Harbor Barrier (DA Acushnet River = 29.4 sq $\mathrm{mi})$ :

* 4,500 ft earth-filled dike harbor barrier with rock slope protection and 4,600 ft dike extension along western waterfront.

* $150 \mathrm{ft}$ wide navigation channel (2 sector gates invert = $-39.0 \mathrm{ft}$ NGVD).

* Top elevations: Harbor Barrier Dike \& Navigation Gates = $20.0 \mathrm{ft}$ NGVD Dike Extension =22.0 ft NGVD.

* One steel swing Street Gate $62 \mathrm{ft}$ wide x $14.5 \mathrm{ft}$ high on Rodney French Blvd.

- Clark Cove Dike and Pump Station:

* 5,800 ft earth-filled dike.

* Top elevation $=22.0 \mathrm{ft}$ NGVD.

* 240 cfs Interior runoff pump station (DA $=760$ acres).

* Two steel swing Street Gates: Cove Road $=62 \mathrm{ft}$ wide $x 14 \mathrm{ft}$ high. Rodney French Blvd. = $62 \mathrm{ft}$ widex $13 \mathrm{ft}$ high.

- Fairhaven Dike:

* 3,100 ft earth-filled dike.

* Top elevation $=20.0 \mathrm{ft}$ NGVD.

Ownership:

- All features (except navigation gate), Operated and Maintained by City of New Bedford - (508) 991-6133.

- Navigation Gate at New Bedford Harbor Barrier Operated and Maintained by NAE Corps of Engineers.

Total cost: $\$ 18,614,000$. 
Placed in operation: J anuary 1966.

Table 2. Water elevations, New Bedford, MA, hurricane barrier.

\begin{tabular}{|l|l|l|}
\hline \multicolumn{3}{|c|}{ Mean Tide Data } \\
\hline Stage & Elev. (ft, NGVD) & \\
\hline Mean high water & 2.4 & \\
\hline Mean low water & -1.3 & \\
\hline Mean tide range & 3.7 & \\
\hline \multicolumn{3}{|c|}{ Water Levels } \\
\hline Date & Elev. (ft, NGVD) & Event \\
\hline \multicolumn{3}{|c|}{ Highest Since Project Construction } \\
\hline $08 / 91$ & 7.6 & Hurricane Bob \\
\hline $01 / 97$ & 6.4 & Coastal storm \\
\hline \multicolumn{3}{|l|}{ Highest Historic } \\
\hline 08/1638 & $14.4 \pm$ & Hurricane \\
\hline 08/1635 & $13.6 \pm$ & Hurricane \\
\hline $09 / 1938$ & 12.5 & Great New England Hurricane \\
\hline $08 / 1954$ & 11.9 & Hurricane Carol \\
\hline $09 / 1815$ & 11.5 & Hurricane \\
\hline $09 / 1944$ & 8.2 & Hurricane \\
\hline $11 / 1944$ & 6.8 & Storm \\
\hline $09 / 1960$ & 6.3 & Hurricane Donna \\
\hline $11 / 1953$ & 6.2 & Storm \\
\hline $\begin{array}{l}\text { N0TE: Start of damage }=4.0 \mathrm{ft} \mathrm{NGVD.} \mathrm{Data} \mathrm{from} \mathrm{the} \mathrm{New} \mathrm{England} \mathrm{District} \mathrm{web} \mathrm{page,} \\
7 \text { December 2006, and General Design Memorandum, June 1961. }\end{array}$ \\
\hline
\end{tabular}




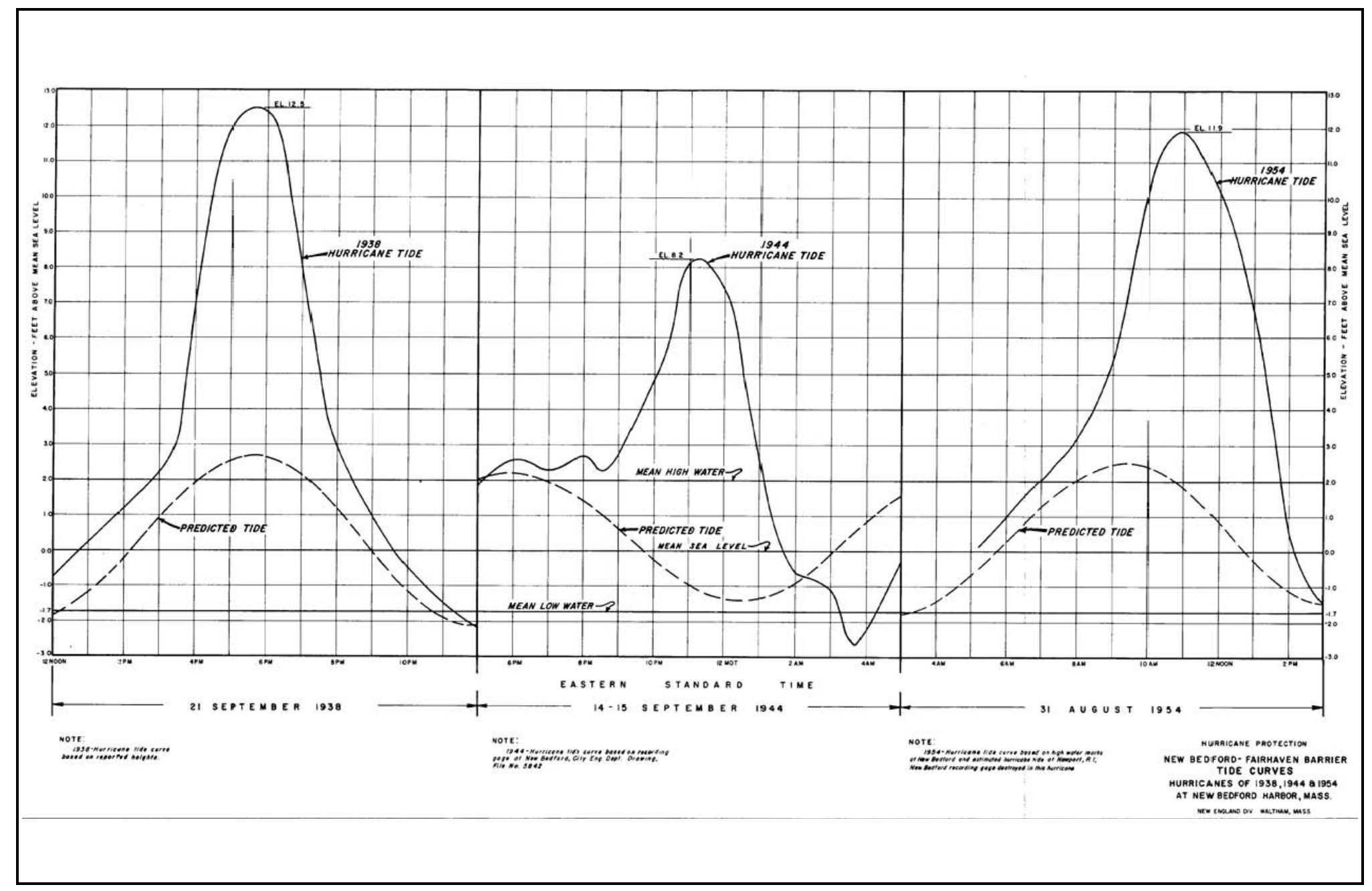

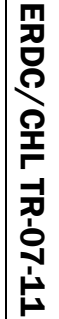

Figure 21. Water elevations for 1938, 1944, and 1954 hurricanes in New Bedford. 


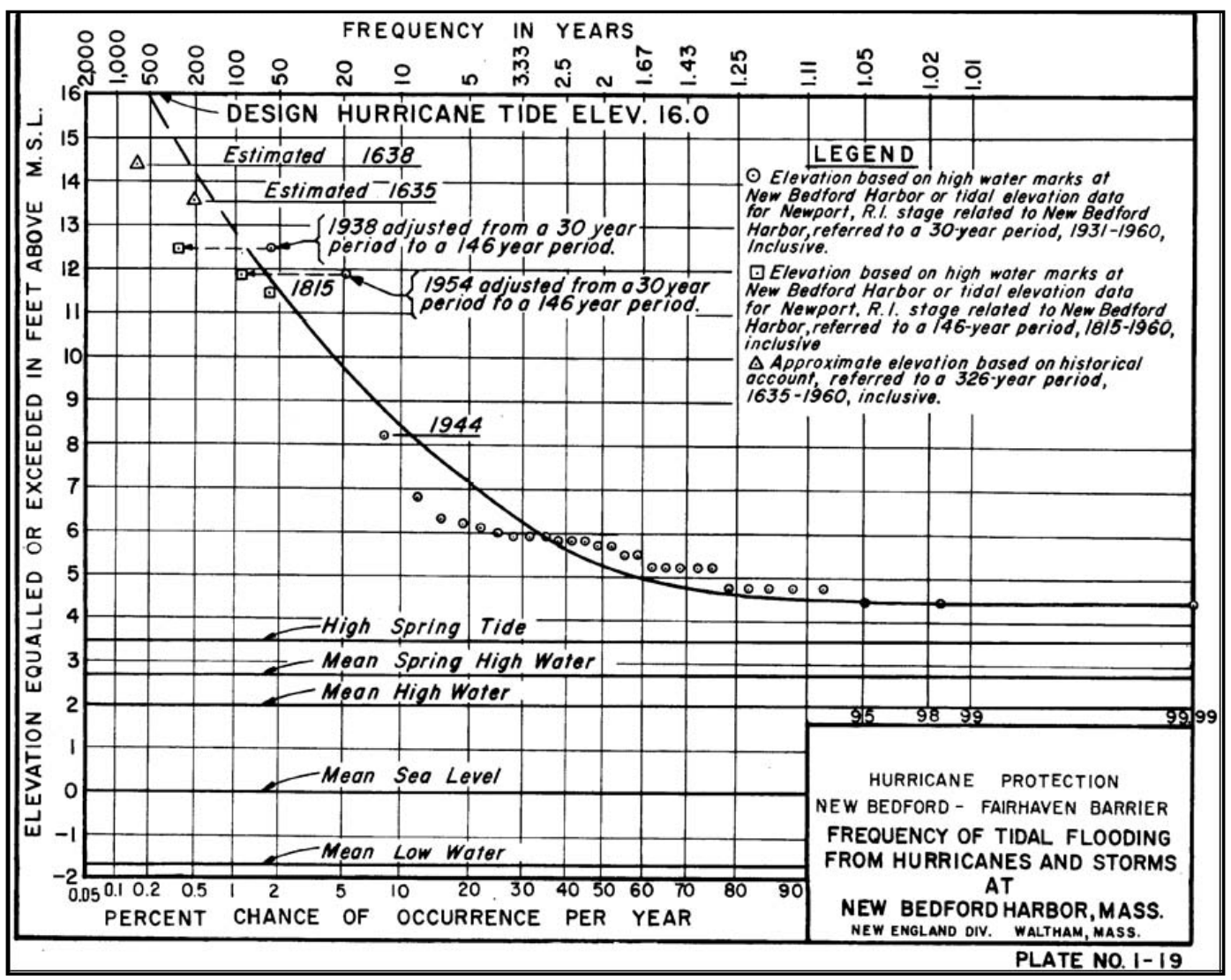

Figure 22. New Bedford elevation-frequency curve.

The rock-faced dike and concrete gate structure were built on a foundation of rock ledge. The site was isolated with coffer dams, dewatered, and excavated to rock basement (Figures 23-27). Stone for the dike came from Dartmouth, MA, a distance of only 3 or 4 miles. The stone workmanship is among the finest that this author has ever seen in a coastal structure outside of Italy. The core of the dike is impermeable, and the crest is wide enough for a crane to use as a roadway (Figure 28). The dike has not needed maintenance since construction.

The main deep-draft channel to New Bedford has an authorized depth of $30 \mathrm{ft}$. Most traffic now consists of fishing boats and barges, but some cruise ships and larger ocean-going freighters use the channel (Figure 29). If larger vessels will need to enter the harbor in the future, the entire gate complex will have to be rebuilt. This will be very difficult now because when the original gate was under construction within its cofferdam, the navigation channel was temporarily rerouted to the east. Now the stone dike blocks this part of the harbor, and there is no other opening through which the navigation channel could be temporarily rerouted. 


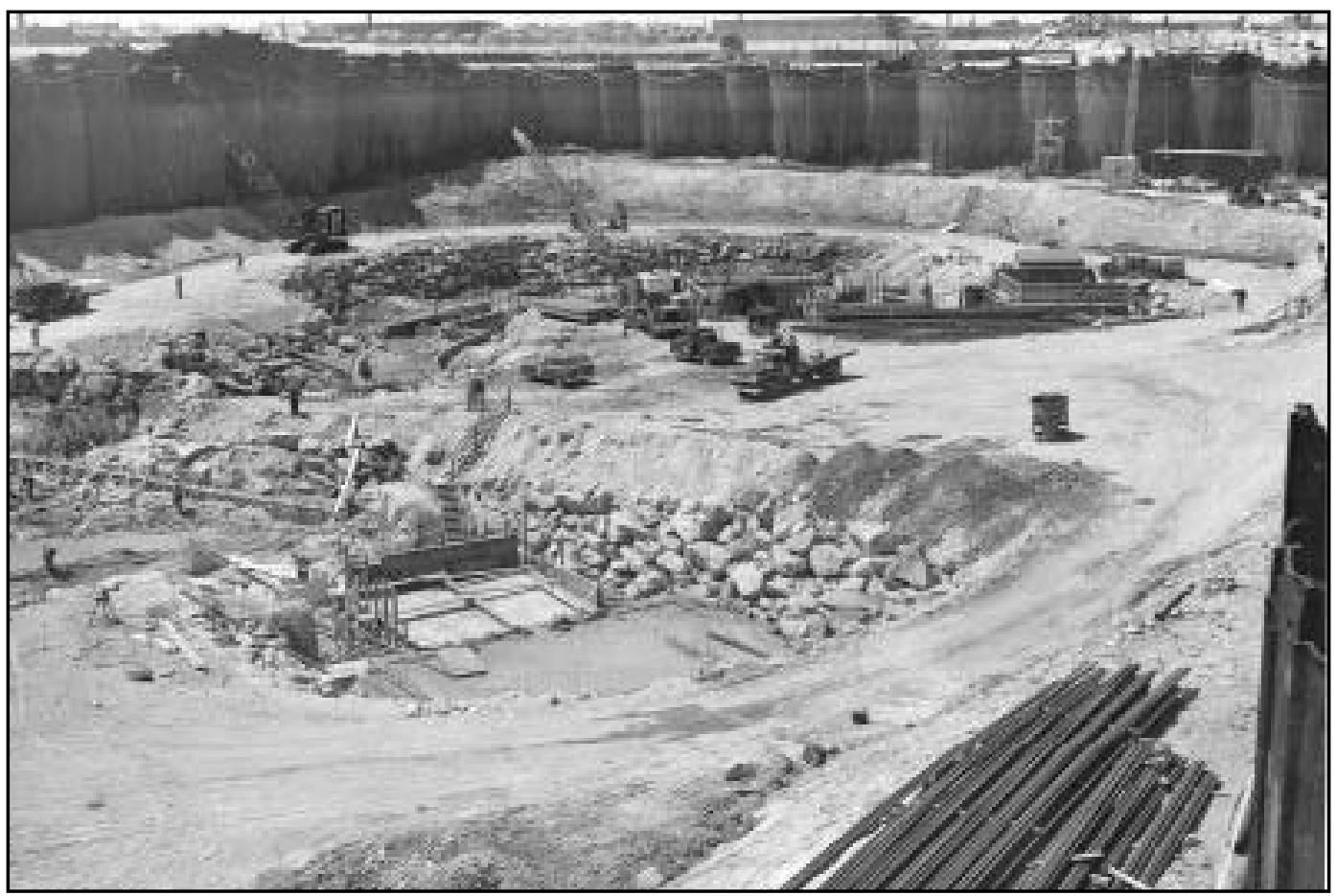

Figure 23. Sector gate foundation work within protective cofferdam, 5 May 1964 (photograph courtesy of New England District).

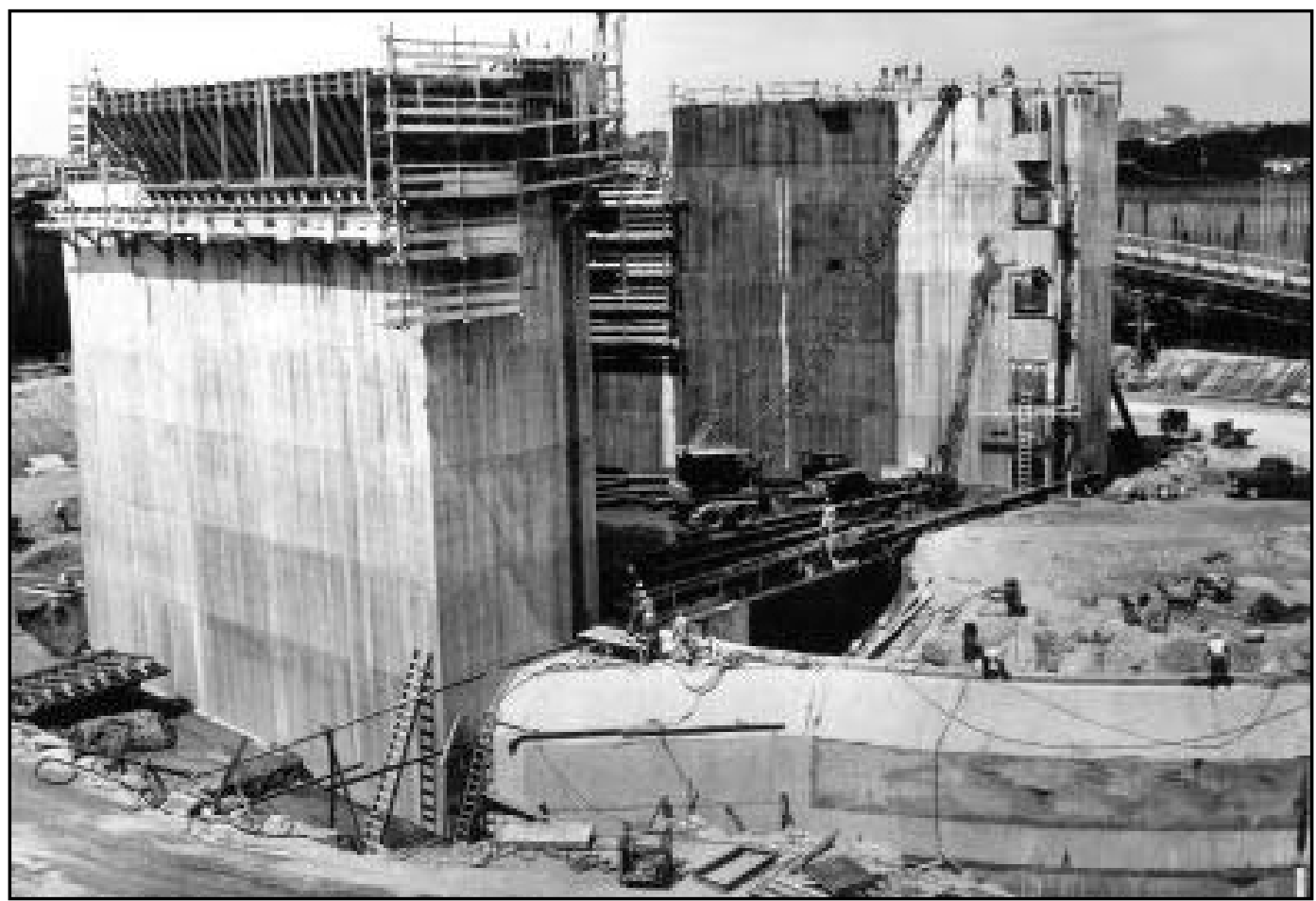

Figure 24. Construction of gate house, 1964. Structure in lower right is guide for gate rollers and also contains tunnel through which gate operators can walk under channel (photograph courtesy of New England District). 


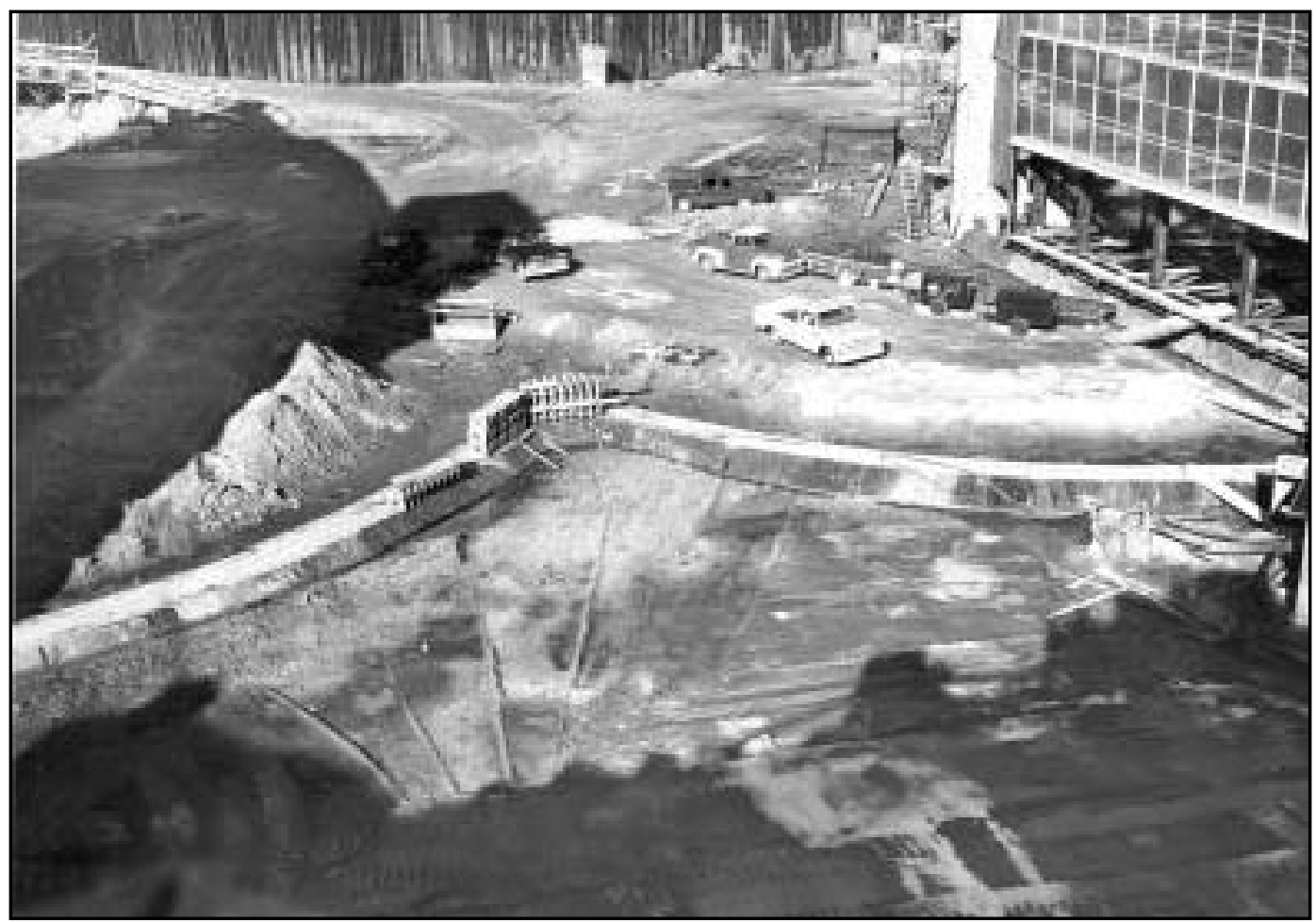

Figure 25. Construction of guide for sector gates, 16 December 1964. Trucks show scale of this project (photograph courtesy of New England District).

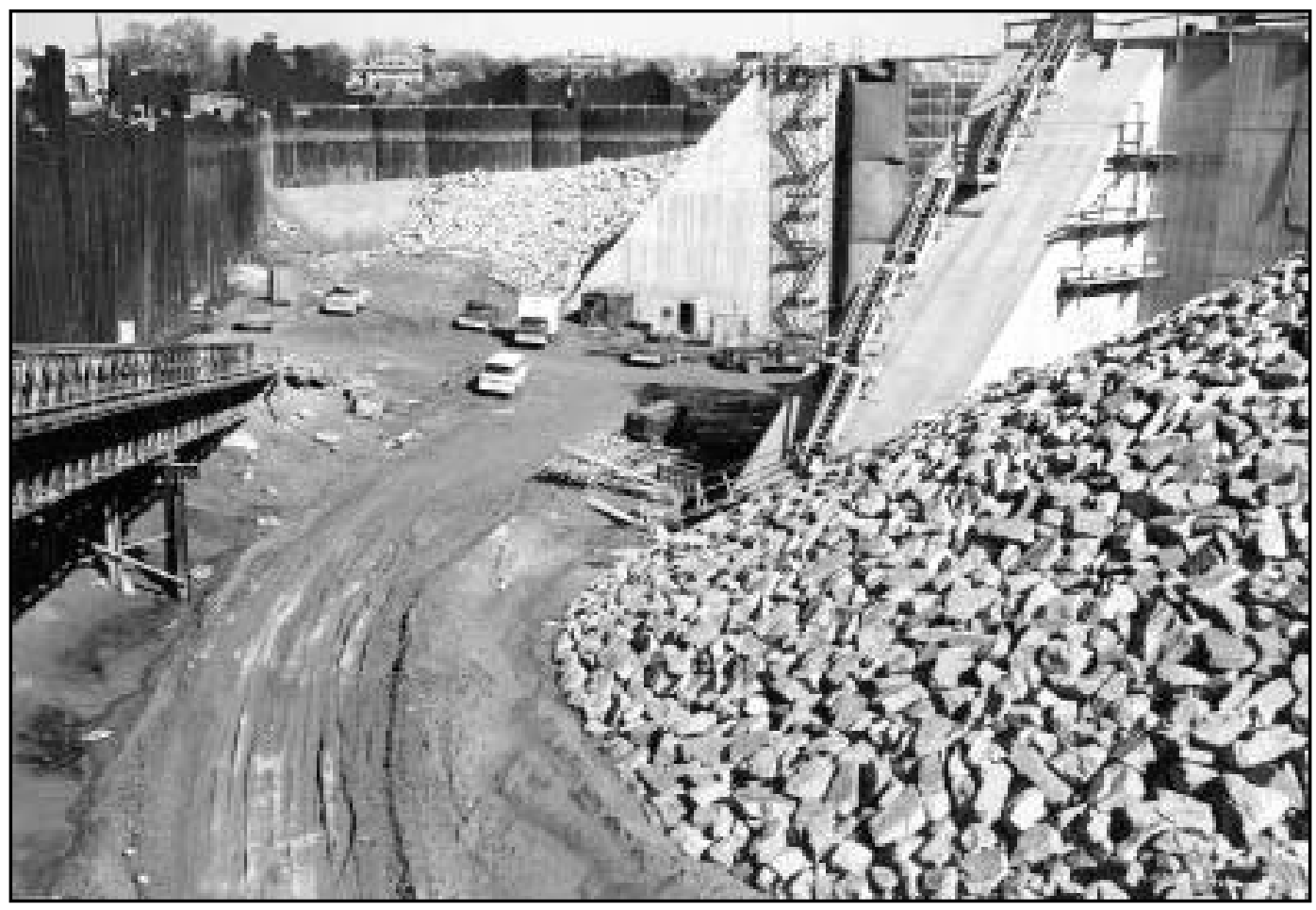

Figure 26. Harbor side of section gate looking east toward Fairhaven, 1965 (photograph courtesy of New England District). 


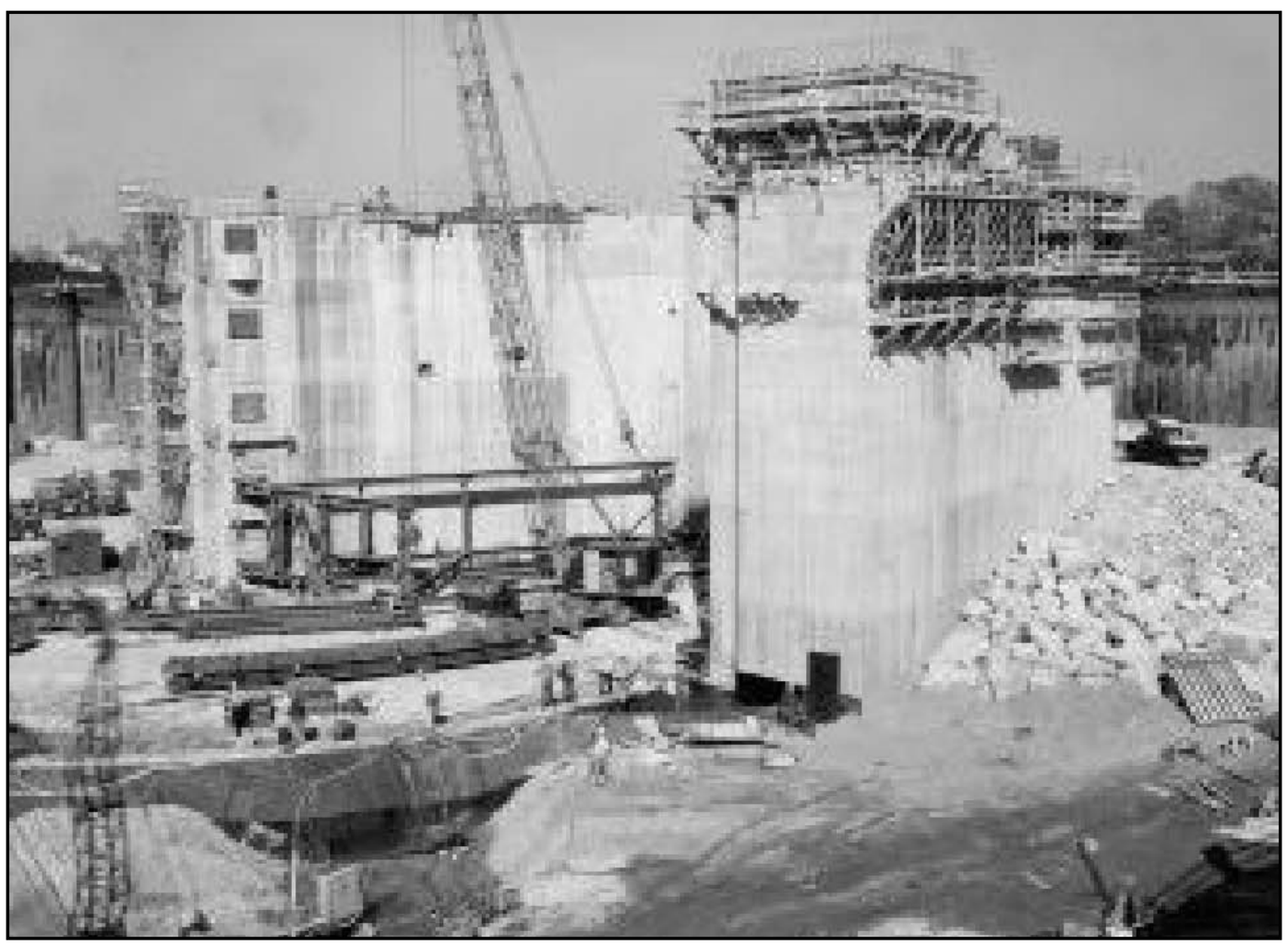

Figure 27. East sector gate steel erection, 15 October 1964 (photograph courtesy of New England District).

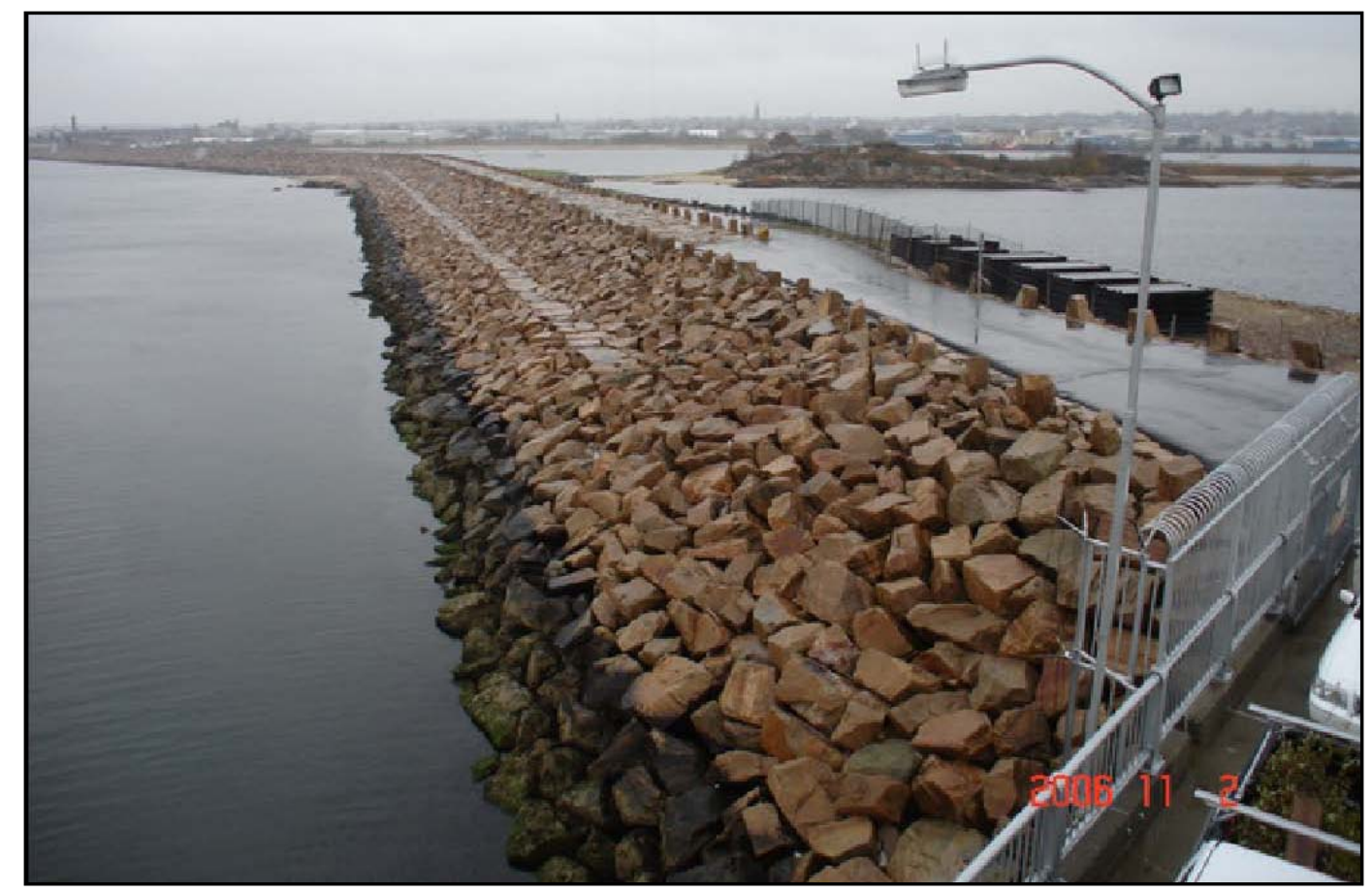

Figure 28. View looking west along New Bedford hurricane dike from gate house, 2 November 2006. 


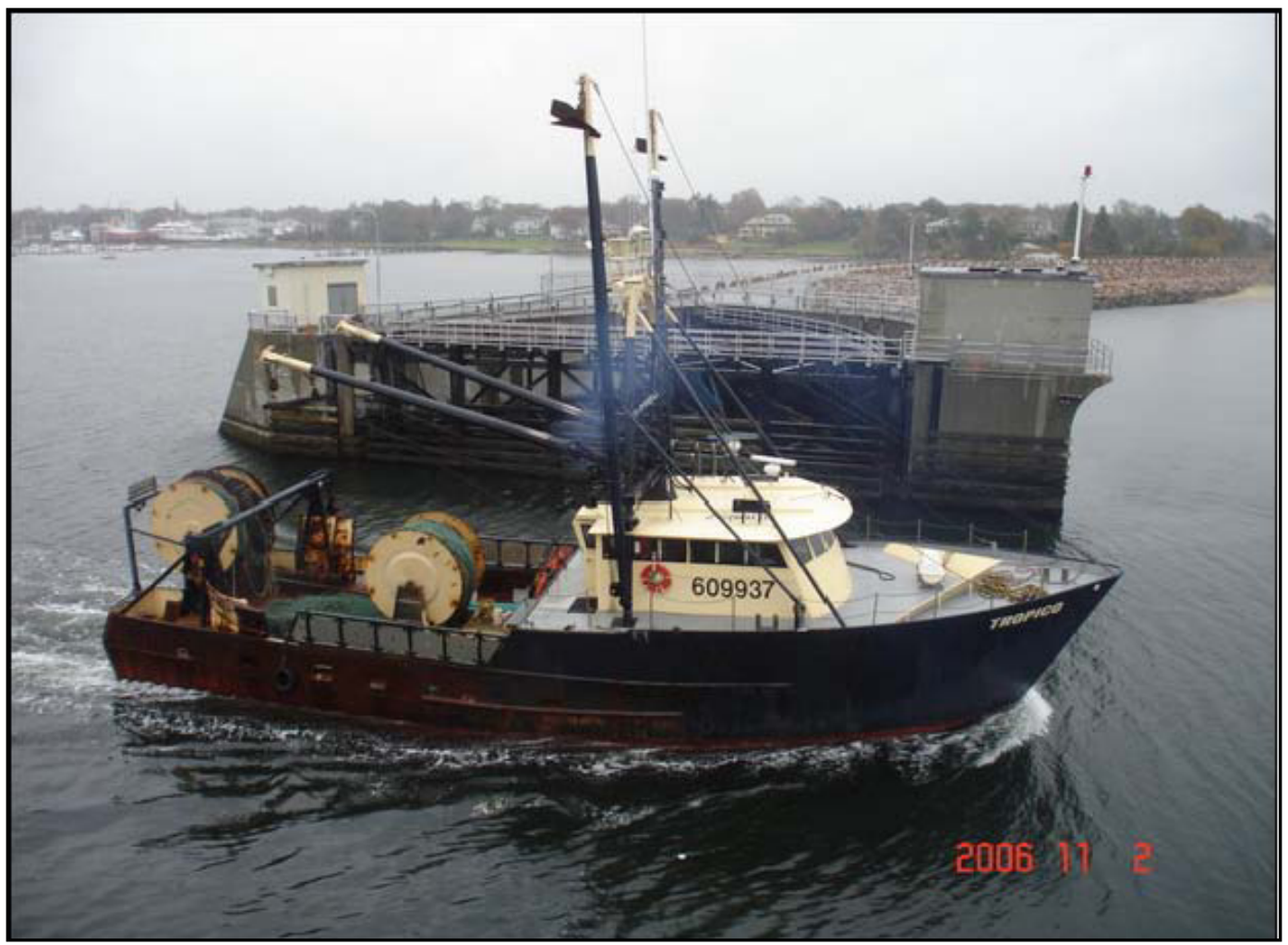

Figure 29. Fishing boat passing through 150-ft-wide Federal navigation channel in New Bedford hurricane barrier. View from gate control house looking east, 2 November 2006.

\section{Operation}

The Reservoir Control Center (RCC) of the New England District is responsible for closure and opening of the navigation gates and maintains close liaison with the National Weather Service, the U.S. Coast Guard, and local authorities (Wiegel 1993). An operational and maintenance manual for the project describes the standard operating procedures, communications protocols, and other particulars. Wiegel (1993) lists more details on the responsibilities of USACE personnel when a hurricane approaches New England. The gates are not operated automatically according to some set water level or other criteria. "Considerable discretion is necessary in initiating closure if approaching vessels are only a short distance from the barrier and will be passing through within 2 or $3 \mathrm{~min}$. The ocean elevation and rate of rise must be considered in delaying closure for marine traffic. The project manager should be in communication with RCC during this sensitive phase of the operation if vessels are approaching" (quoted in Wiegel 1993). 
The gates are used at least once or twice a month, whenever a high tide greater than $+3 \mathrm{ft}$ coincides with a south or southwest wind. Tide predictions and closure instructions are transmitted from the New England District's Cape Cod office, and operators have to be on duty in the control house around the clock when a high-water stage is anticipated. In effect, this project has become a regular part of water-level control for New Bedford harbor. The project operator reiterated to this author that the barrier has never been used to hold back a tide or surge anywhere near its peak design height.

The control house is on the west side of the channel and contains the operators' quarters, machinery, a generator, and access steps to the tunnel that passes under the channel. The gates are 400-ton steel structures which swing horizontally across the 150 -ft-wide channel (Figure 29). Each gate fits into a well in its respective side of the channel (Figures 30 and 31) and is pivoted by a $25 \mathrm{hp}$ electric motor via a gearbox. Electricity is normally supplied by the municipal power grid, but a diesel generator on site can provide power. Although there is backup electricity, there is no emergency means such as a winch or pulleys to move the gates if the electric motor, gearbox, or controls fail. This is in contrast to Providence, where the gates could be lowered into the channel by hand if necessary (although they could not be raised manually).

New England District technicians regularly perform tests and adjustments on the sector gates and tracks, wheels and trunnions, drive pins and sprockets, gate drive gear unit, sluice gates, diesel generator, traveling crane, sump pumps, and cathodic protection pieces. They regularly sound within the gate pockets to determine the amount of shoaling. 


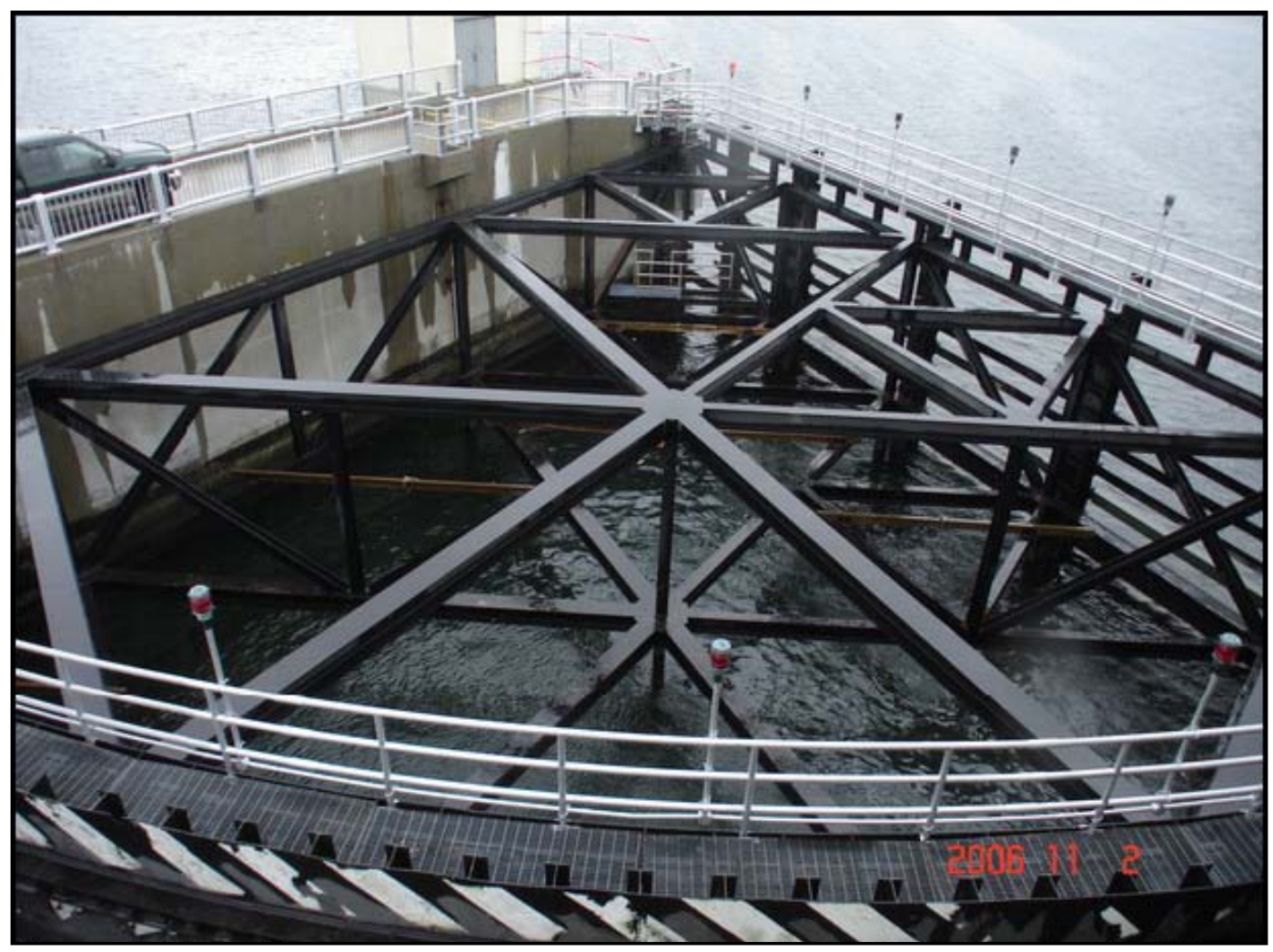

Figure 30. West side section gate in rest position, New Bedford hurricane barrier. Pivot is at upper center of photograph and ship channel is to right.

When the gates are moving across the channel, a roller runs in a channel cast into the top of the tunnel (Figures 24 and 25). Because the channel fills with silt, a compressed air system was installed with nozzles near the roller to clean out the channel. The air is also needed to clear silt in the gate pockets where the gates are parked in their open position. This has not been fully satisfactory, and a pump system to maintain a constant flow of water to flush the pockets has been proposed. 


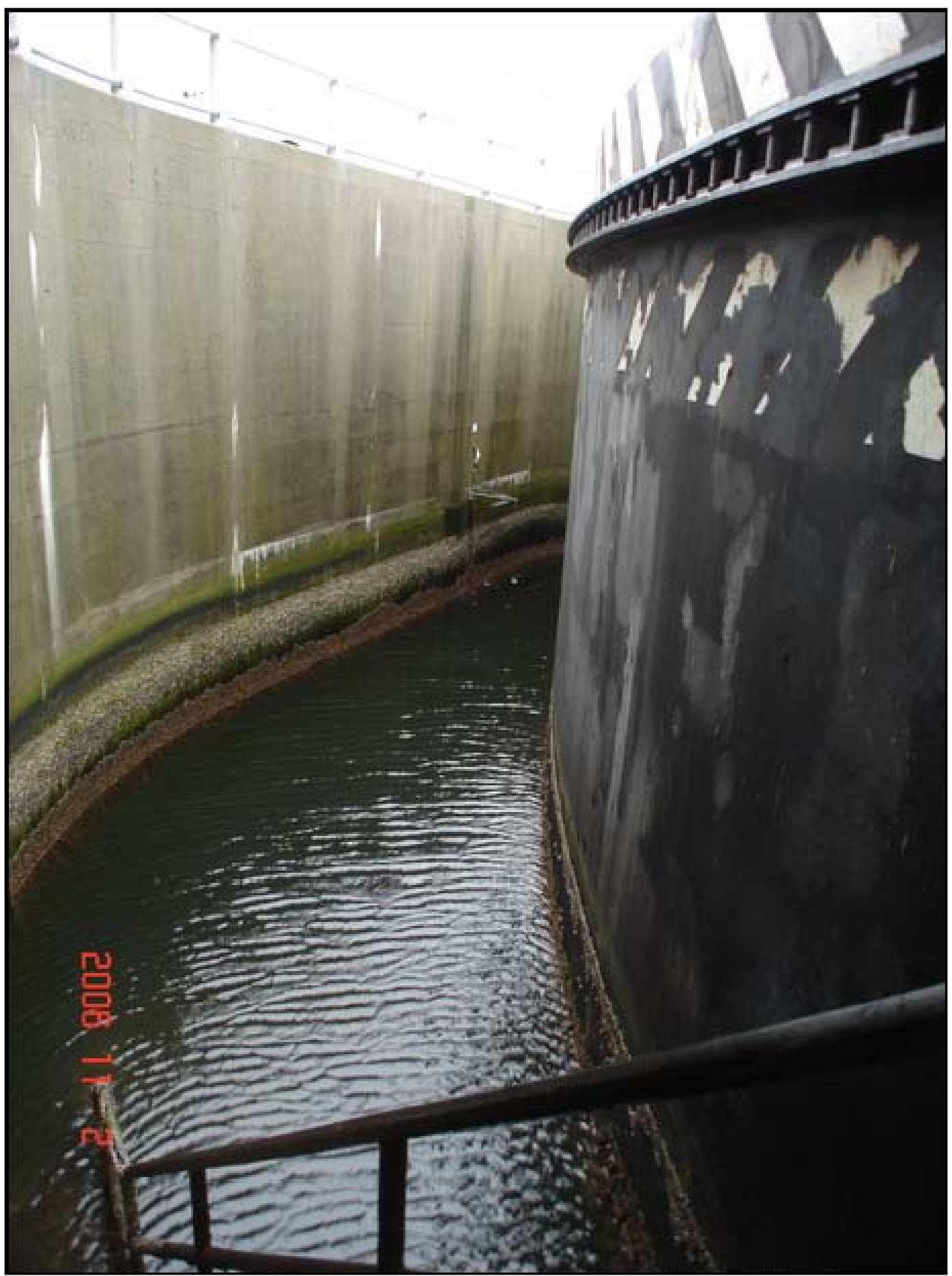

Figure 31. West side section gate in its well. Cogs near top of gate are engaged by teeth of opening mechanism. Silt builds up in well and has to be flushed with compressed air, but gates are often difficult to fully retreat.

Similar to Providence, the electric controls are the original 1960s technology. The gate operator keeps the mechanical equipment in excellent condition up to the limits of his budget. The gates are 
periodically painted, and zinc plates are used to reduce corrosion. Fishing boats have periodically hit the concrete walls, but these accidents have not caused structural damage, and cracks and spalling concrete have been repaired.

Along with the 18,000 $\mathrm{ft}$ of dike, the project includes two steel swing gates to seal off city streets (Figure 32) and a pumping station at Clark Cove (Figure 33). These are operated by the City of New Bedford. At Clark Cove, a broad grassy area about the size of a soccer field serves as a catchment basin for storm water runoff. The pump station was built by the USACE as part of the original project.

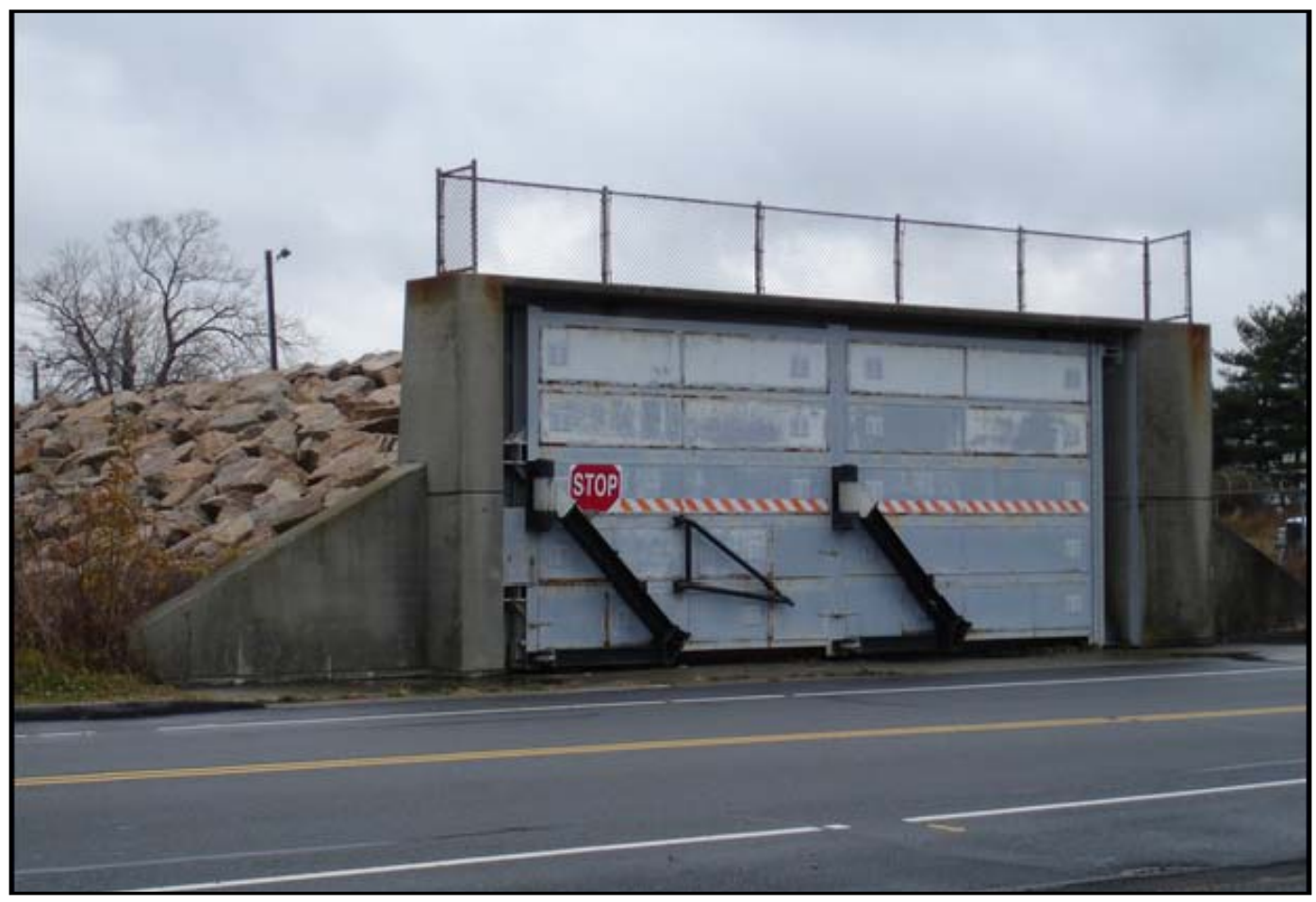

Figure 32. Steel swing gate at E Rodney French Boulevard, New Bedford. 


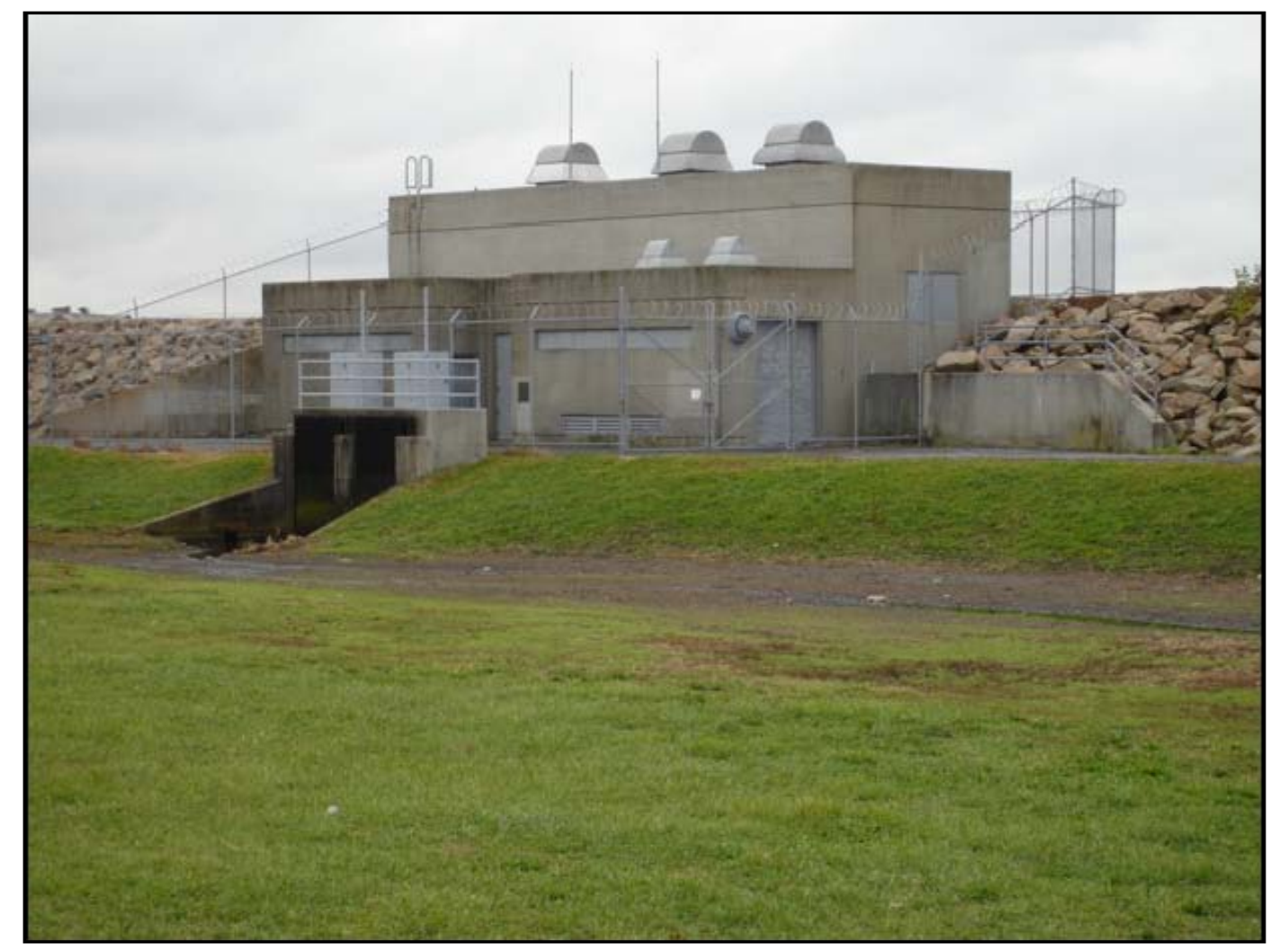

Figure 33. Clark Cove pump station, operated by City of New Bedford. Grassy field in foreground serves as temporary storage after heavy rain.

\section{Environmental factors}

New Bedford was an important industrial, whaling, and ship-building center for three centuries. The 18,000-acre New Bedford Harbor Superfund site extends from the northern reaches of the Acushnet River estuary south through the commercial harbor of New Bedford and into Buzzards Bay. The site contains sediment contaminated with polychlorinated biphenyls (PCBs) and heavy metals. The city's main working port, which houses the fishing fleet and cruise ship terminal, is not affected by the cleanup in the north region of the harbor. There is extensive literature that discusses the cleanup and ongoing attempts to bring new industry to the port and revitalize the city, but information on the direct effects of the hurricane project is scarce. On its web page, the Environmental Protection Agency states: ${ }^{1}$

Environmental effects of hurricane barrier. Although researchers have studied characteristics of the harbor after the

1 From EPA web page: http://www.epa.gov/nbh/html/post-textile.html, 13 December 2006. 
hurricane barrier was built, only a few have addressed the possible effects of the barrier. One researcher reported that sediment is now accumulating faster in some areas of the harbor inside the barrier. Another suggested that less water is now being exchanged between the inner and outer harbors. A recent preliminary modeling study, designed specifically to evaluate the effects of the barrier, calculated that residence time of water inside the barrier increased up to 30 percent. The same modeling study also calculated that the pattern of water circulation near the barrier had changed, with the water forming gyres just north and south of the barrier during certain parts of the tidal cycle. The north gyre would mix incoming water more and thereby affect sedimentation patterns; the south gyre would recirculate water and wastes leaving the harbor, allowing part of that water to be swept back inside the barrier during the next incoming tide.

As of December 2006, the New Bedford barrier is being examined under a NOAA/ Massachusetts study for which the New England District is providing technical guidance and review. The focus is on circulation impacts, water quality impacts (using nitrogen as an indicator), and potential alternatives to mitigate problems (if any) that are caused by the barrier. ${ }^{1}$

There is only one environmental document pertaining directly to the hurricane barrier, the 1972 Final Environmental Statement (New England Division 1972). The document stated that the gate pockets were highly productive biologically and temporary turbidity induced by the compressed air system did not have any detrimental affects on marine life. The document also noted rodent populations were a problem in some areas of the dike and that the USACE helped the City of New Bedford with rodent control.

During the site visit on 2 November 2006, this author saw many cormorants (Phalacrocorax auritus) swimming in the channel and harbor and resting on the concrete walls (Figure 34). Other seabirds were also diving for fish.

\footnotetext{
${ }^{1}$ Mr. John Winkelman, New England District, personal communication, 15 December 2006.
} 


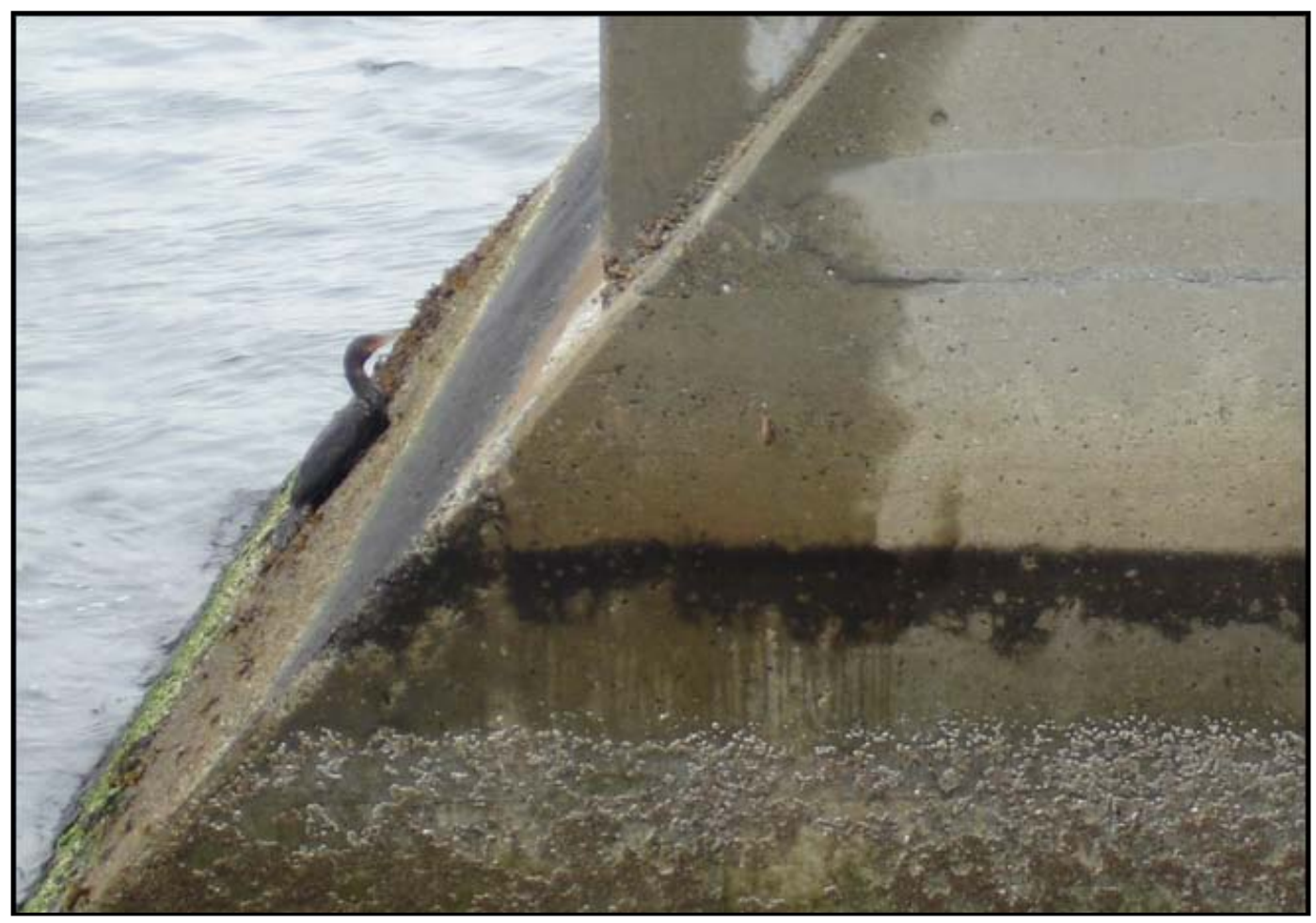

Figure 34. Double-crested Cormorant resting on gate abutment, 2 November 2006. 


\section{New London, CT, Protection Barrier}

\section{Project description}

The following project summary is from the New England District ${ }^{1}$ and Figures 35 and 36 show project features:

The New London Hurricane Protection Barrier is located along the New London waterfront at Shaw Cove on the Thames River. It is about 45 miles southeast of Hartford.

New London suffered damaging floods from hurricanes in 1938, 1944, 1954, and 1960. Damages from 1954's Hurricane Carol amounted to $\$ 3.8$ million, of which $\$ 2.4$ million could have been prevented if a hurricane protection barrier had existed. The barrier today protects about 173 acres of industrial and commercial areas in the vicinity of Shaw Cove from hurricane and severe coastal storm flooding, and safeguards against interior flooding caused by overflows from Truman Brook.

Construction started in August 1978 and was completed in May 1986, costing \$12 million. The relocation of electric, water, sewer, telephone, and drainage lines was required. The barrier is operated and maintained by the city.

The project consists of an earthfill dike with stone slope protection approximately $715 \mathrm{ft}$ long with a maximum elevation of $14.5 \mathrm{ft}$; a concrete floodwall about $800 \mathrm{ft}$ long with a maximum elevation of $14.5 \mathrm{ft}$; two revetments that have a total length of $925 \mathrm{ft}$; a gated 1,800-ft-long concrete conduit $8 \mathrm{ft}$ in diameter that intercepts flows from Truman Brook and discharges into Shaw Cove; and a pumping station that discharges flows through the dike during unusually high tides. The project also included the construction of a raised railroad embankment, the dredging of Shaw Cove, and the demolition of waterfront structures.

\footnotetext{
1 From the New England District Water Resources web page: http://www.nae.usace.army.mil/ water/topic.asp?mytopic=newlondon-fdr, 13 November 2006.
} 


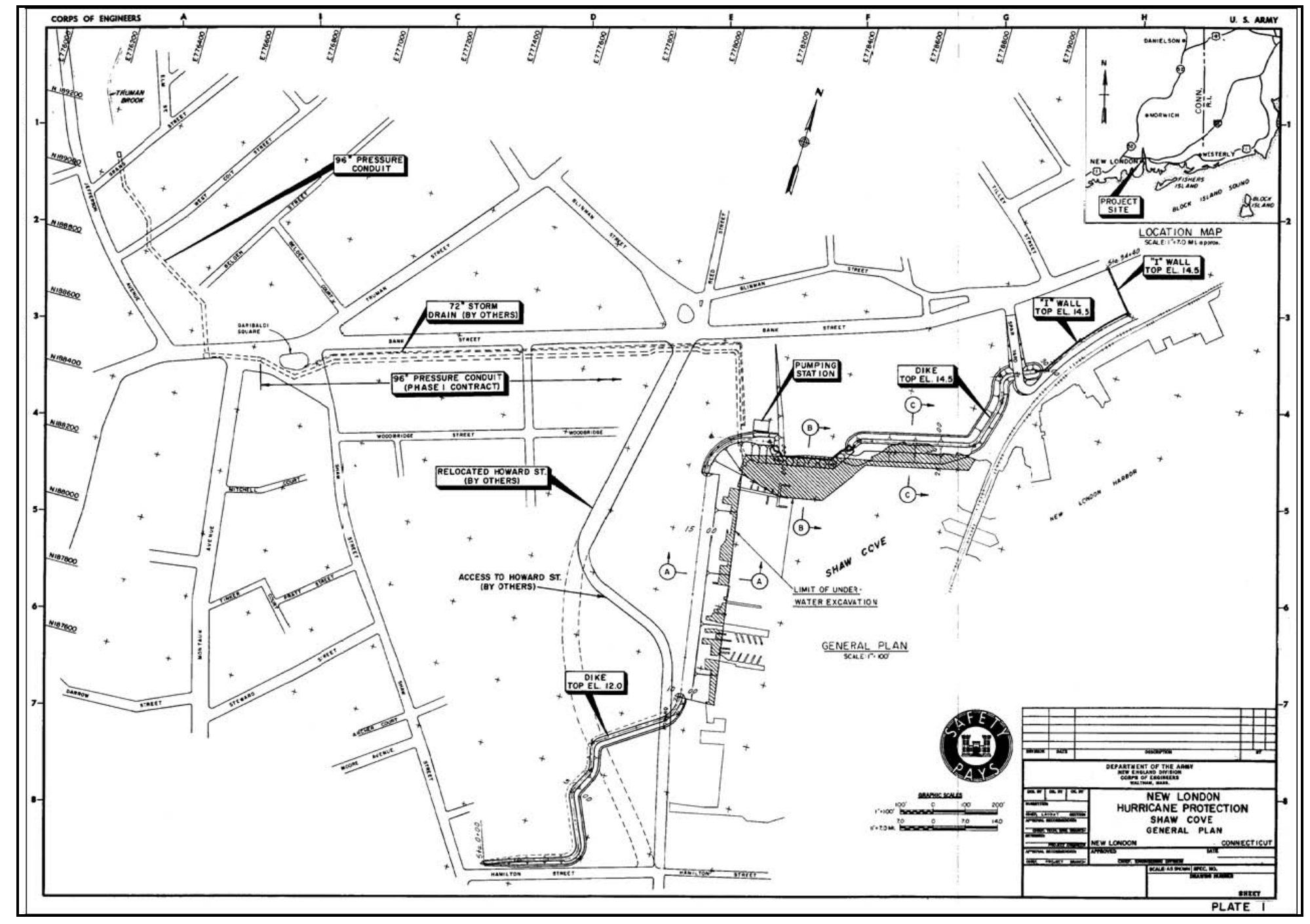

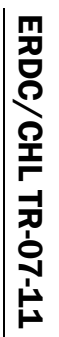

Figure 35. New London project features (12-ft dike in south area was never built). 


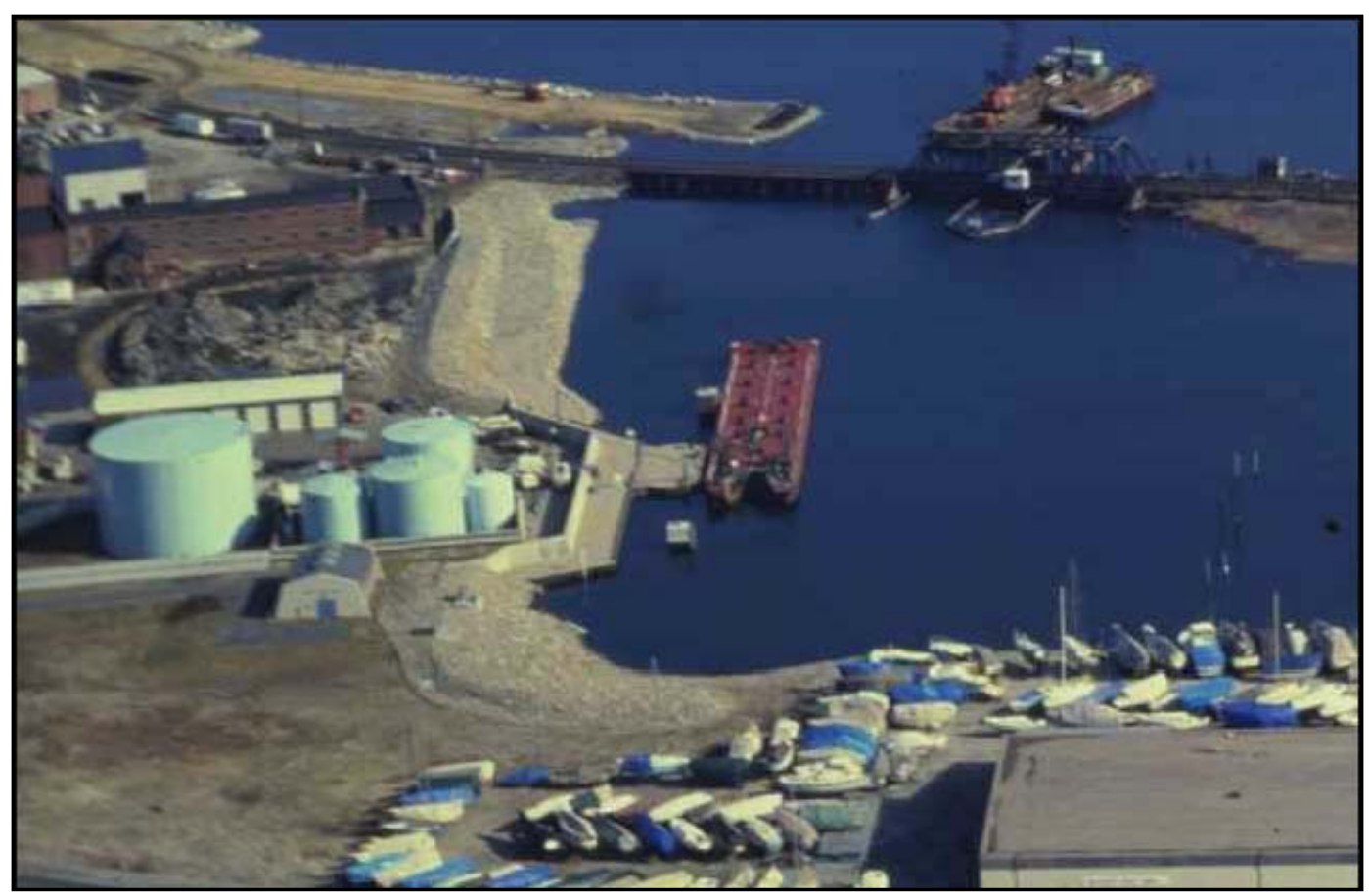

Figure 36. New London, CT, dike, 2005 (photograph courtesy of New England District).

\section{Design and details}

Table 3 lists water levels, and Figure 37 shows curves for the 1938 and 1954 hurricanes. The following description is from the New England District web page:

New London barrier was designed for a 100-year stillwater elevation of $10.5 \mathrm{ft}-\mathrm{NGVD}$. This level is equivalent to a surge of $8.6 \mathrm{ft}$ coincident with a mean spring high water tide of $1.9 \mathrm{ft}-$ NGVD. Maximum wave runup is approximately $4 \mathrm{ft}$ resulting in a top elevation of the barrier to be $14.5 \mathrm{ft}-\mathrm{NGVD}$. The pumping station, gravity conduit, and pressure conduit, were designed for a 10-year, 100-year and 100-year runoff, respectively.

Project features:

- Design Hurricane Tide $=10.5 \mathrm{ft}$ NGVD.

- $715 \mathrm{ft}$ earth-filled dike.

- $800 \mathrm{ft}$ concrete wall.

- Top Elevation $=14.5 \mathrm{ft}$ NGVD.

- 96-inch diameter pressure conduit from Truman Brook to Shaws Cove.

- Interior runoff Pump Station of 210 cfs (DA = 755 acres). 
Total cost: $\$ 11,500,000$.

Placed in operation: J anuary 1985.

Note that the protection level is for a 100 -year storm, whereas the Providence and New Bedford projects were designed for a 500-year event. The original plan for New London was more comprehensive and was to include a dike around Bentley's Creek, located south of Fort Trumbull. This part of the New London project was never built. Staff at the New England District do not know the reason why the project was reduced in scope. The as-built project was incorporated into an urban-renewal program where land was elevated behind the dikes.

Table 3. New London, CT, protection barrier.

\begin{tabular}{|c|c|c|}
\hline \multicolumn{3}{|c|}{ Mean Tide Data } \\
\hline Stage & Elev. (ft, NGVD) & \\
\hline Mean high water & 1.7 & \\
\hline Mean low water & -0.9 & \\
\hline Mean tide range & 2.6 & \\
\hline \multicolumn{3}{|c|}{ Water Levels } \\
\hline Date & Elev. (ft, NGVD) & Event \\
\hline \multicolumn{3}{|c|}{ Highest Since Project Construction } \\
\hline 09/1985 & 6.0 & Hurricane Gloria \\
\hline $01 / 1987$ & 5.5 & Coastal storm \\
\hline \multicolumn{3}{|c|}{ Highest Historic } \\
\hline 09/1938 & 9.7 & Great New England Hurricane \\
\hline 08/1954 & 8.9 & Hurricane Carol \\
\hline $11 / 1950$ & 6.7 & Storm \\
\hline $09 / 1944$ & 6.2 & Hurricane \\
\hline 09/1960 & 6.0 & Hurricane \\
\hline $\begin{array}{l}\text { NOTE: Start of da } \\
7 \text { December } 200\end{array}$ & $\begin{array}{l}0 \mathrm{ft} \text { NGVD. Data } \\
\text { neral Design Me }\end{array}$ & $\begin{array}{l}\text { e New England District web pag } \\
\text { lum No. 2, July } 1977 .\end{array}$ \\
\hline
\end{tabular}




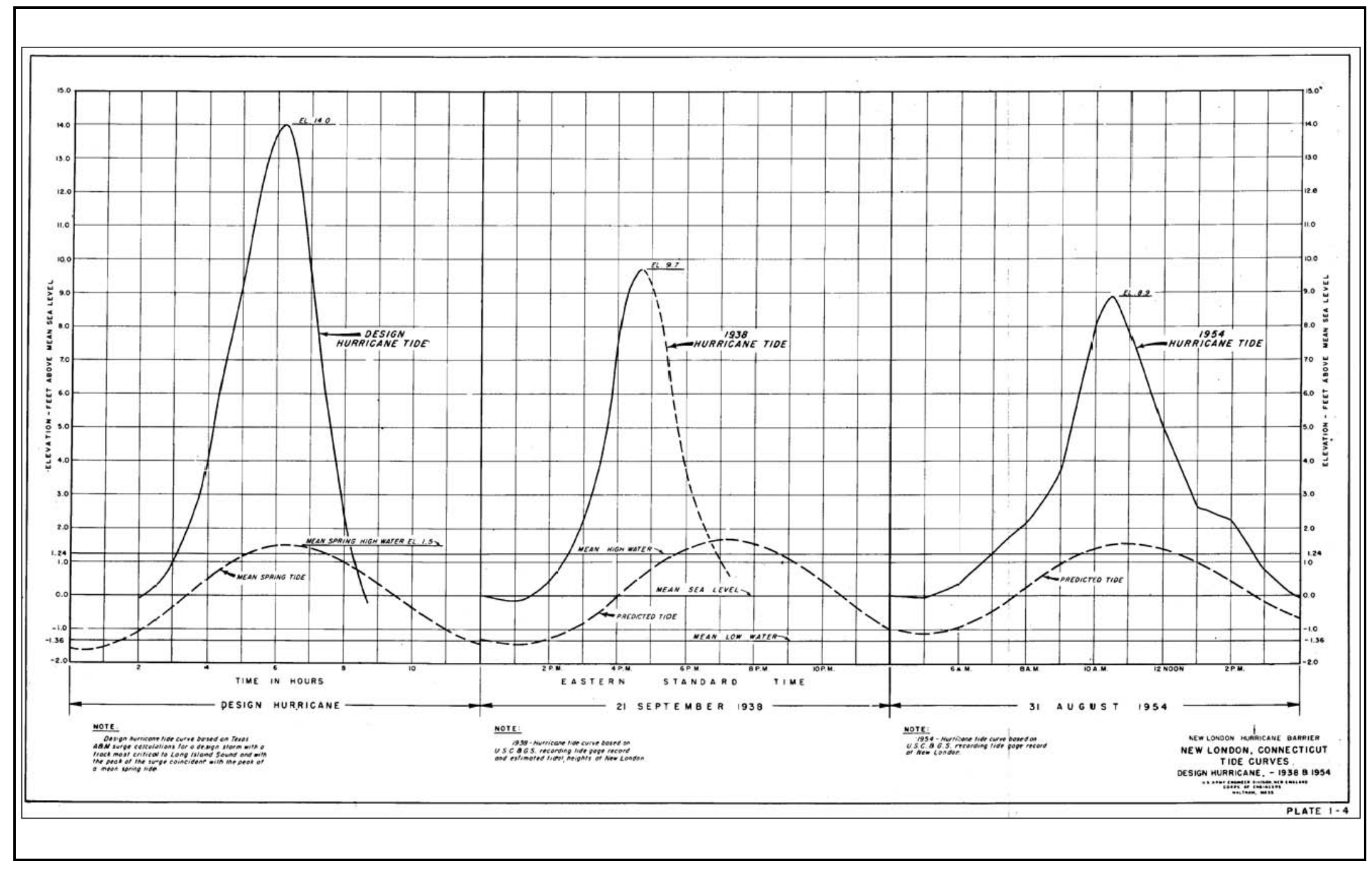

Figure 37. Water elevation for 1938 and 1954 hurricanes in New London. 


\section{Environmental factors}

The Shaw Cove dike enclosed an industrial area and did not affect wetlands or enclose open water. It did not affect any known historic natural or environmental education sites. The dikes were installed on land and therefore did not affect fish resources. A Final Impact Statement was filed with the Council of Environmental Quality on 25 August 1976.

In a comment letter filed with the General Design Memorandum, the U.S. Department of the Interior recommended that non-structural alternatives be investigated as an alternative to building the dikes. They recommended relocating the urban renewal area out of the flood zone. It is unclear if this option was considered earlier in the planning phase for this project. Other agencies were in favor of the dike project precisely because it would allow urban renewal, increase employment, and have other benefits to an economically depressed region. 


\section{Pawcatuck Hurricane Protection, Pawcatuck, CT}

\section{Project description}

The following description is from the New England District ${ }^{1}$ and Figures 38 and 39 show project elements:

The Pawcatuck Hurricane Protection Barrier is located in the Pawcatuck section of Stonington on the west bank of the Pawcatuck River.

Like other Connecticut coastal communities, Pawcatuck has suffered serious flooding from hurricanes in 1938, 1944, 1954, and 1960 , as well as other severe coastal storms. Hurricane Carol of 1954 caused damages estimated at $\$ 1.09$ million, of which about $\$ 851,000$ could have been prevented if a hurricane protection barrier had existed at that time. Today, the barrier protects 34 acres of highly industrialized land from tidal surges.

Construction began in J une 1962, and was completed in September 1963. The cost of the project was $\$ 859,000$. Operation and maintenance is the responsibility of Stonington.

The project consists of 1,915 ft of earthfill dike and $940 \mathrm{ft}$ of concrete wall, both with an elevation of $17 \mathrm{ft}$; two vehicular gates; and a pumping station. The project protection begins 0.7 mile south of the U.S. Route 1 Bridge and extends 2,200 ft northward along the west bank of the river.

The project protects about 34 acres of highly industrialized land from hurricane-induced surges on the Pawcatuck River. The lower portion of the river forms the border between Rhode Island and Connecticut and drains into Little Narragansett Bay, a bay partially sheltered from Long Island Sound by Napatree Point. The Point was heavily settled before the

\footnotetext{
1 From the New England District Water Resources web page: http://www.nae.usace.army.mil/ water/topic.asp?mytopic=pawcatuck-fdr, 13 November 2006.
} 
1938 hurricane, when the houses and Fort Mansfield were overwashed and destroyed.

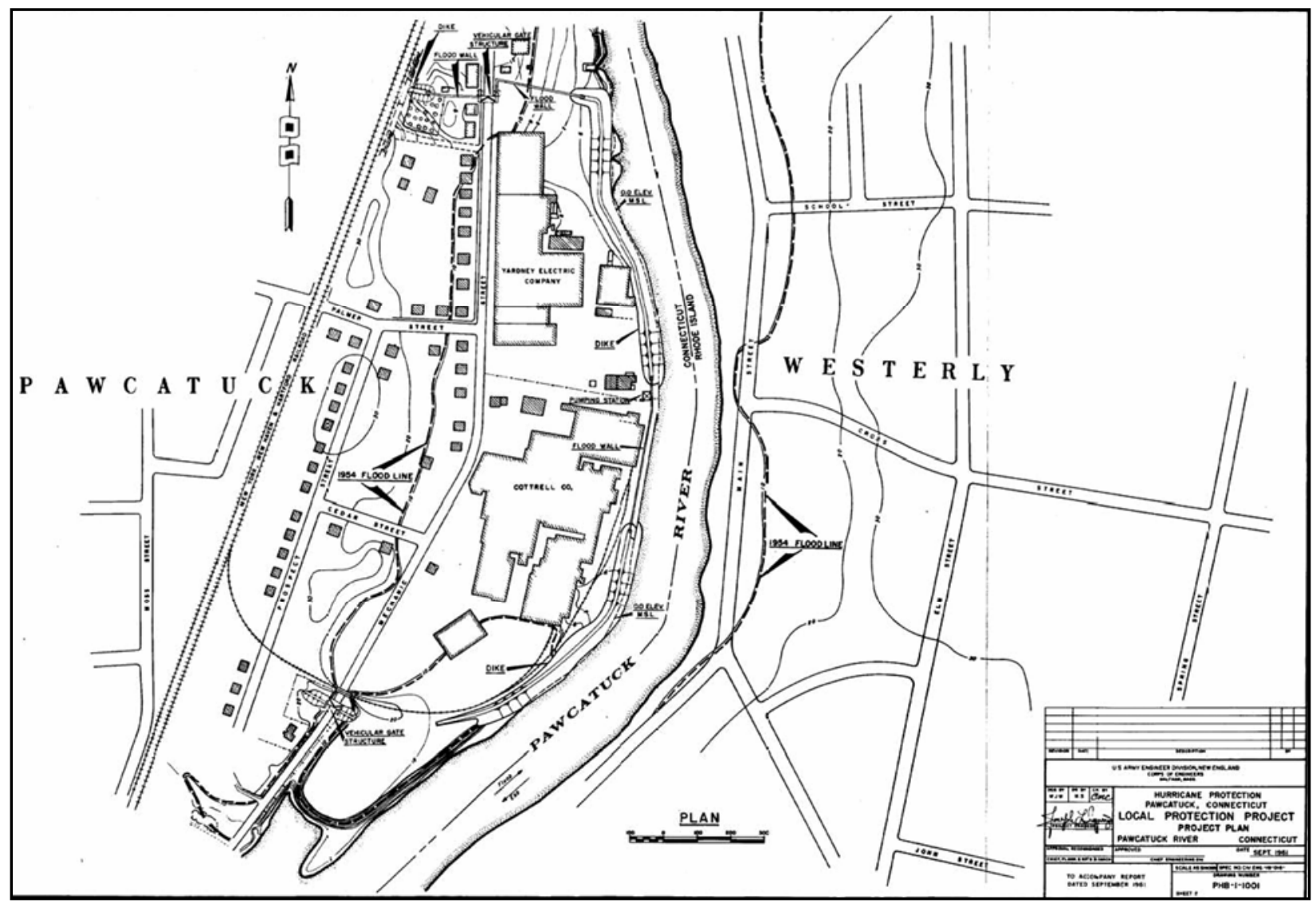

Figure 38. Pawcatuck, CT, protection project elements. 


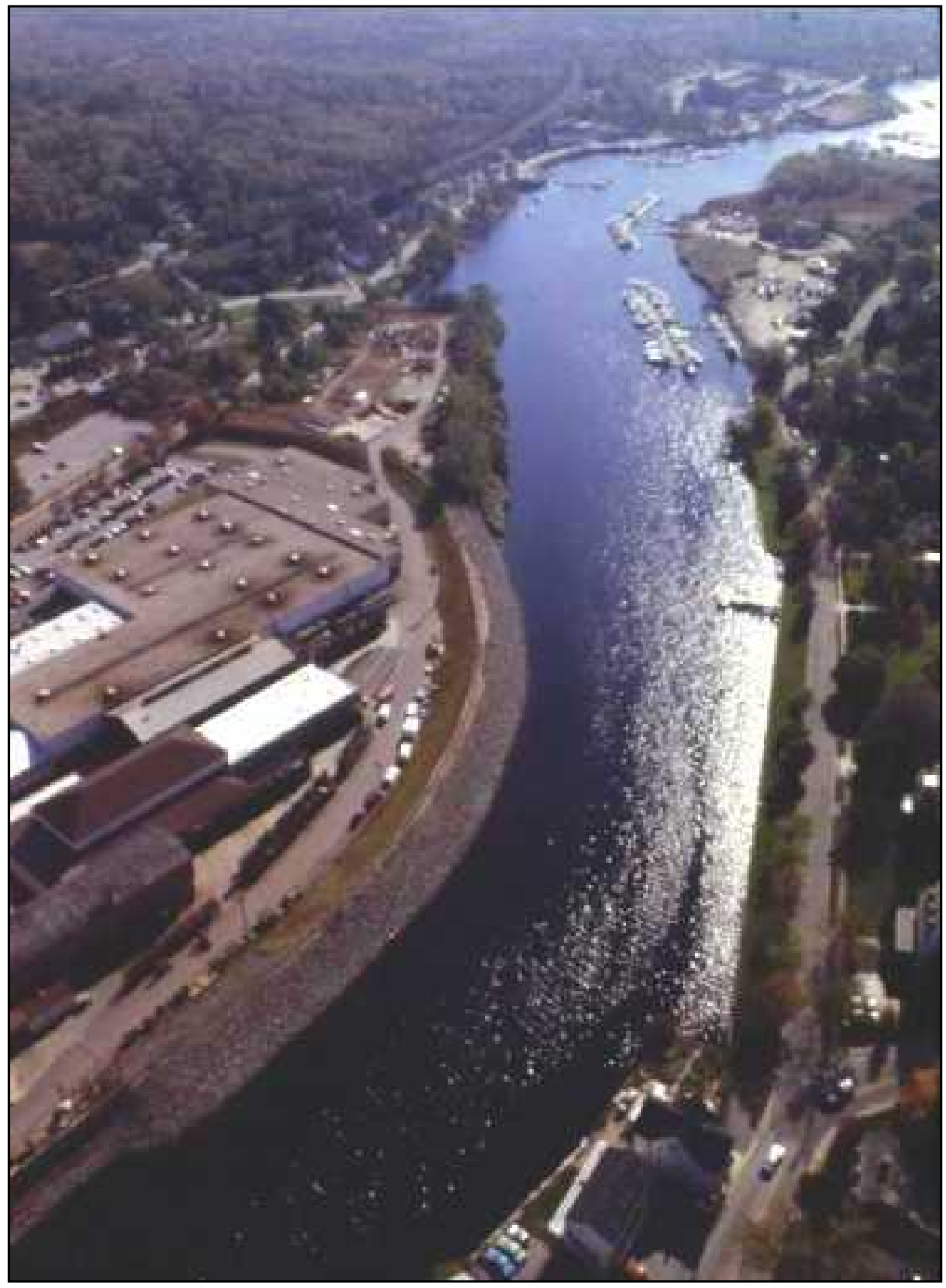

Figure 39. Pawcatuck, CT, protection project (photograph courtesy of New England District). 


\section{Design and details}

The following design summary is from the New England District web page. ${ }^{1}$ Table 4 lists water levels and Figure 40 shows the storm curves.

The Design Hurricane was established through cooperation with the U.S. Weather Bureau and the Beach Erosion Board affiliated with the Texas Research Foundation of Texas A\&M University. The basis for the design storm was the transformation of the September 1944 hurricane. This storm, when it was off the Cape Hatteras, NC, coast, had the greatest energy of any known hurricane along the Atlantic coast. The 1944 storm was transposed so that it would be entirely over water between Cape Hatteras and the New England coast, resulting in a central pressure of 27.88 in. mercury near New Haven, CT. The transposed storm was moved northerly with a forward speed of about 40 knots along a track passing over New England 49 nautical miles west of Montauk Point, and moving northerly directly over New Haven creating sustained winds of $90 \mathrm{mph}$. Within Little Narragansett Bay, at the mouth of the Pawcatuck River, a tide surge associated with this storm was computed to be $14.2 \mathrm{ft}$. This surge was added to the mean spring high water elevation of $1.3 \mathrm{ft}-\mathrm{NGVD}$, resulting in a 15.5 Ft-NGVD stillwater elevation. Transposing this level upstream to the project resulted in a design tide elevation of $16.5 \mathrm{ft}-\mathrm{NGVD}$. It was further determined that no wave from Long Island Sound would affect the project location. A $16.5 \mathrm{ft}-\mathrm{NGVD}$ elevation is approximately a 500-year tide level.

Project features:

- Design Hurricane Tide = $16.5 \mathrm{ft}$ NGVD.

- $1,915 \mathrm{ft}$ earth-filled dike.

- $940 \mathrm{ft}$ concrete wall.

- Top Elevations = $17.0 \mathrm{ft}$ NGVD.

- Interior runoff Pump Station of $50 \mathrm{cfs}$ (DA=34 acres).

- 2 Vehicle Street Gates on Mechanic Street $44 \mathrm{ft}$ wide $8 \mathrm{ft}$ high.

- Standard Project Flood =7,800 cfs (DA Pawcatuck River = 295 sq mi).

\footnotetext{
1 From the New England District web page: https://rsgis.crrel.usace.army.mil/nae/pls/ nae/nae_web.nae_webmenu.displaymenu?menu=main, 1 December 2006.
} 
Total cost: $\$ 860,000$.

Placed in operation: September 1963.

Table 4. Pawcatuck, CT, protection plan.

\begin{tabular}{|c|c|c|}
\hline \multicolumn{3}{|c|}{ Mean Tide Data } \\
\hline Stage & Elev. (ft, NGVD) & \\
\hline Mean high water & 1.0 & \\
\hline Mean low water & -1.5 & \\
\hline Mean tide range & 2.5 & \\
\hline \multicolumn{3}{|c|}{ Water Levels } \\
\hline Date & Elev (ft, NGVD) & Event \\
\hline \multicolumn{3}{|c|}{ Highest Since Project Construction } \\
\hline \multicolumn{3}{|l|}{ (not available) } \\
\hline \multicolumn{3}{|c|}{ Highest Historic } \\
\hline 09/1938 & 11.1 & Great New England Hurricane \\
\hline $08 / 1954$ & 10.4 & Hurricane Carol \\
\hline 09/1944 & 7.6 & Hurricane \\
\hline $11 / 1950$ & 7.2 & Storm \\
\hline $09 / 1960$ & 6.8 & Hurricane Donna \\
\hline 02/1960 & 5.5 & Storm \\
\hline $02 / 1958$ & 5.1 & Storm \\
\hline
\end{tabular}

\section{Environmental factors}

Similar to New London, this was also a land project that did not affect wetlands or open water. There appear to be no post-construction environmental studies or reports. 


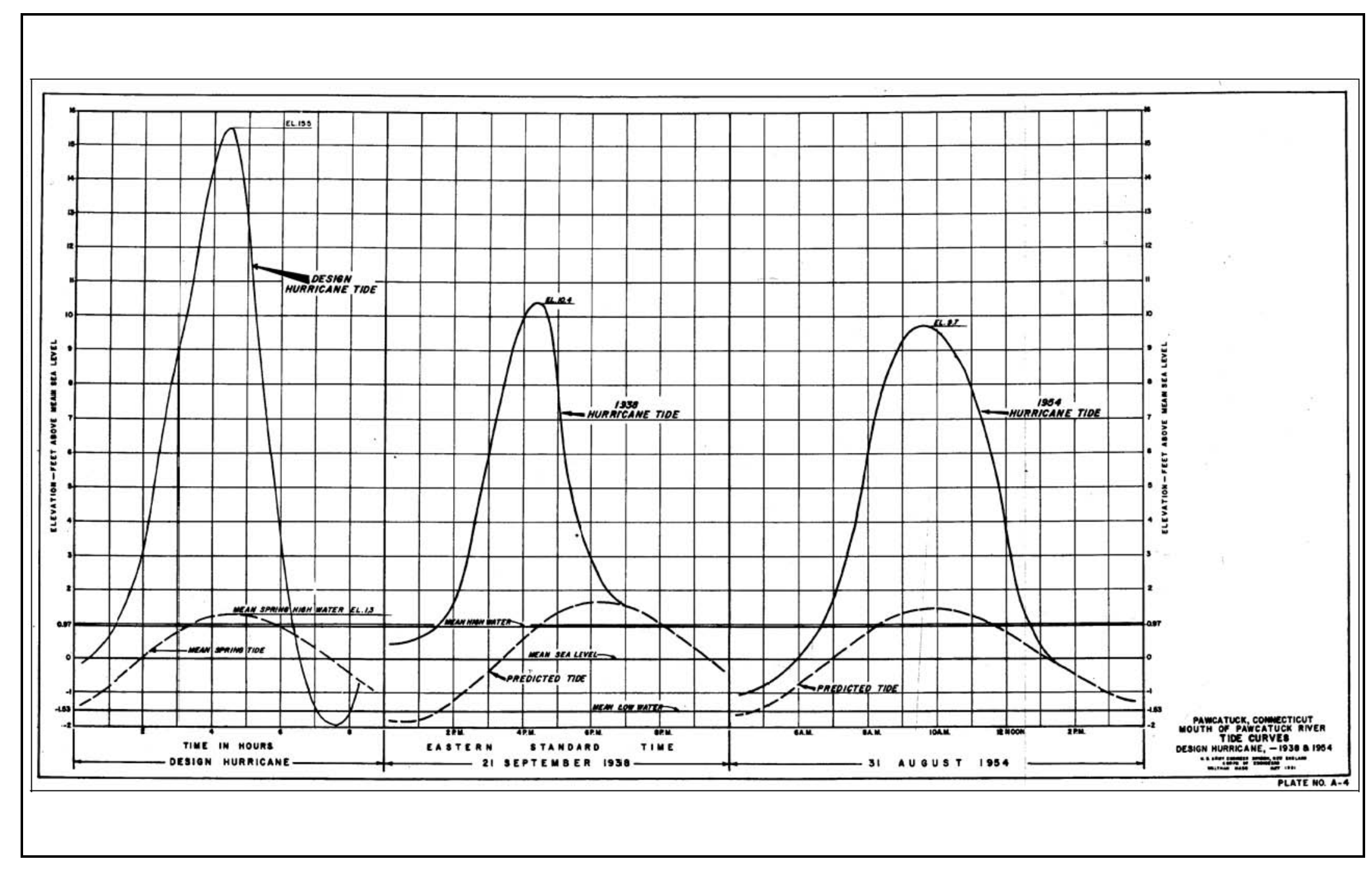

Figure 40. Pawcatuck, CT, hurricane levels. 


\section{Stamford, CT, Hurricane Barrier}

\section{Project description}

Figures 41,42 , and 43 show project elements. The following description is from the New England District web page: ${ }^{1}$

The Stamford Hurricane Protection Barrier is located in Stamford on Stamford Harbor, about 20 miles southwest of Bridgeport.

Stamford has been subject to heavy losses from storm tidal flooding since 1635. The September 1938 hurricane resulted in losses in the project area of almost \$6 million. Hurricane Carol in 1954 caused \$3.4 million in damage, of which \$2.9 million could have been prevented if a hurricane barrier had existed at that time. The barrier today provides protection to about 600 acres, which includes principal manufacturing plants, a portion of the main commercial district, and residential sections.

Construction of this project started in May 1965 and ended in J anuary 1969, costing $\$ 14.5$ million. The city operates and maintains the Stamford Hurricane Protection Barrier, with the exception of the navigation gates, which are operated and maintained by the Corps.

The project consists of three elements. The first, a barrier at the east branch of Stamford Harbor, is composed of a 2,850-ft-long earthfill dike with stone slope protection. It has an elevation of $17 \mathrm{ft}$. A 90 -ft-wide opening is provided for navigation, and a pump station discharges interior drainage.

The second element is a barrier that provides protection at the west branch of the harbor. This barrier, which has an elevation of $17 \mathrm{ft}$, is composed of a 1,350-ft-long concrete wall; 2,950 ft of earthfill dike with stone slope protection and a pumping station. The third portion provides protection at Westcott Cove. This

\footnotetext{
1 From the New England District Water Resources web page: http://www.nae.usace.army.mil/ water/topic.asp?mytopic=stamford-fdr, 13 November 2006.
} 
barrier is a 4,400-ft earthfill dike with stone slope protection having a maximum elevation of $19 \mathrm{ft}$. It also has two pumping stations.

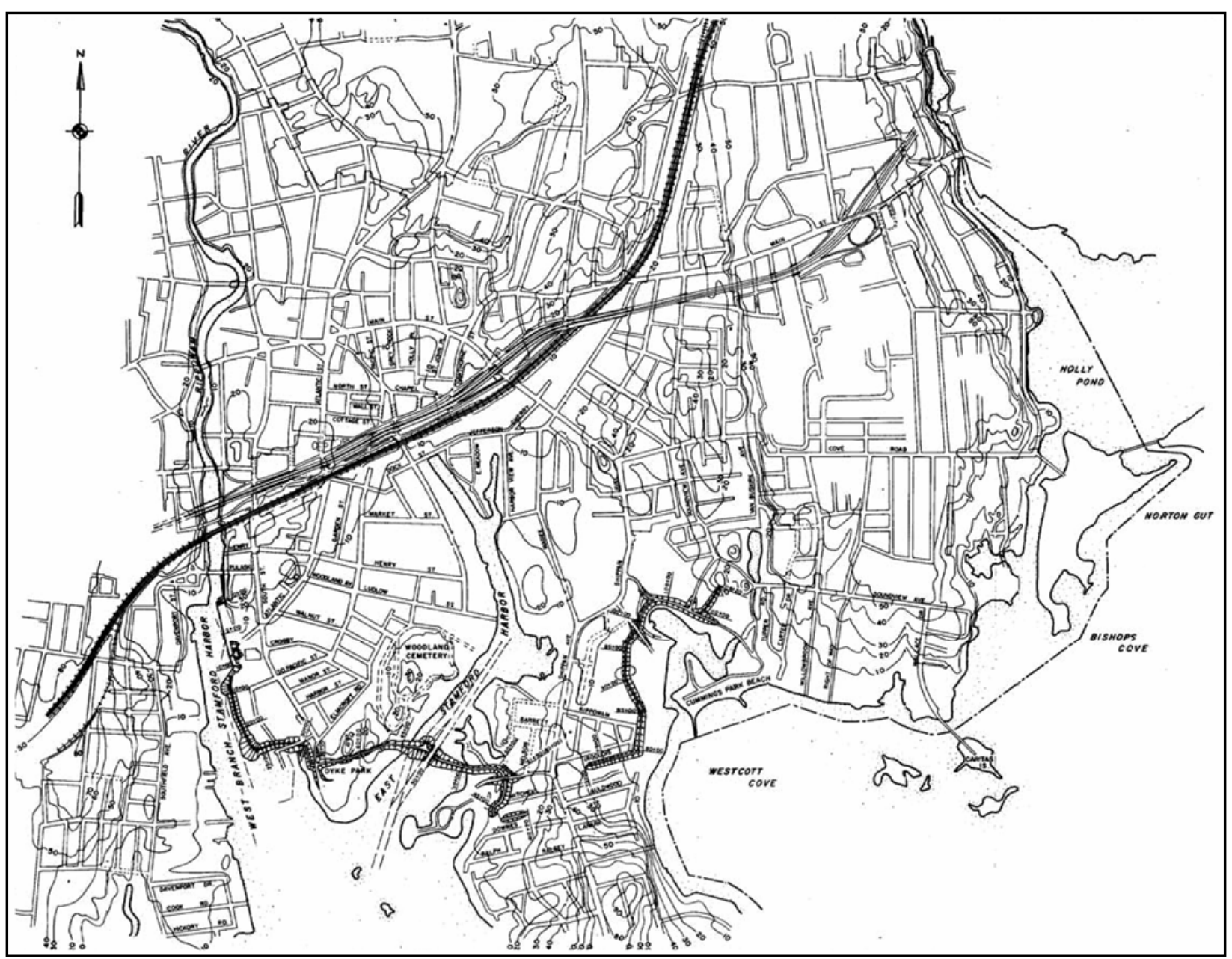

Figure 41. Stamford, CT, hurricane project elements. 


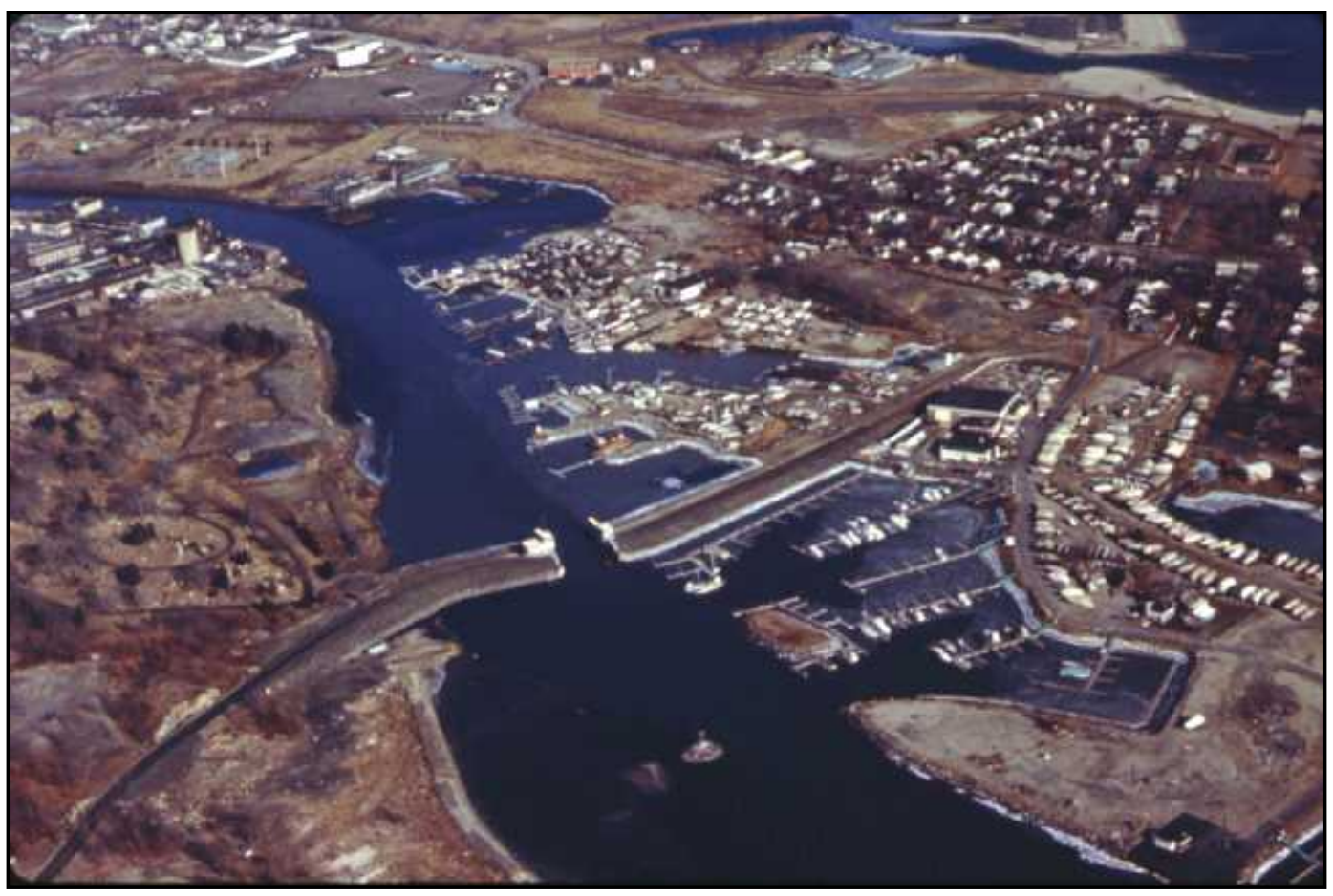

Figure 42. Aerial photograph of Stamford hurricane barrier (photograph courtesy of New England District).

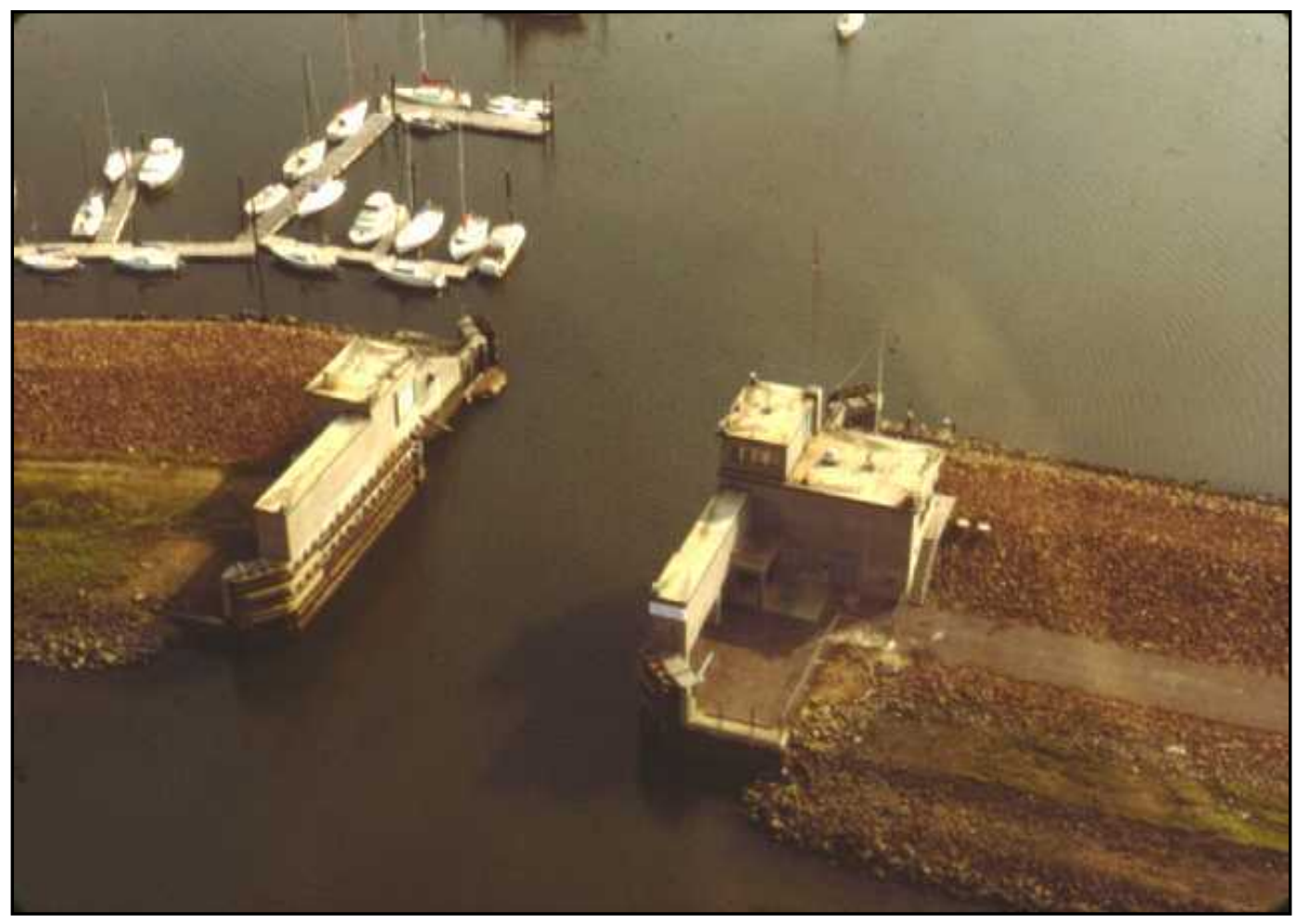

Figure 43. Stamford hurricane barrier (photograph courtesy of New England District). 


\section{Design and details}

The following design summary is from the New England District web page. ${ }^{1}$ Table 5 lists historic water levels and Figure 44 is a plot of prominent hurricane water levels.

The Design Hurricane was established through cooperation with the U.S. Weather Bureau and the Beach Erosion Board affiliated with the Texas Research Foundation of Texas A\&M University. The basis for the design storm was the transformation of the September 1944 hurricane. This storm, when it was off the Cape Hatteras, NC, coast, had the greatest energy of any known hurricane along the Atlantic coast. The 1944 storm was transposed so that it would be entirely over water between Cape Hatteras and the New England coast, resulting in a central pressure of 27.8 in. mercury near the mouth of Narragansett Bay, Buzzards Bay, and Long Island Sound. The transposed storm was moved northerly with a forward speed of about 40 knots along a track passing over New England 49 nautical miles west of Montauk Point, Long Island, creating sustained winds of $90 \mathrm{mph}$ at the mouth of Long Island Sound and $55 \mathrm{mph}$ from the southwest quadrant at the Stamford location in western Long Island Sound. Within Long Island Sound, at Stamford, a tide surge associated with this storm was computed to be $10.4 \mathrm{ft}$. This surge was added to the mean spring high water elevation of $4.4 \mathrm{ft}-\mathrm{NGVD}$, resulting in a $14.8 \mathrm{ft}$ NGVD stillwater elevation. It was further determined that wave heights associated with this storm would be on the order of about $2.0 \mathrm{ft}$ at time of peak surge resulting in a top of barrier elevation of $17.0 \mathrm{ft}-\mathrm{NGVD}$. A $14.8 \mathrm{ft}$-NGVD design stillwater elevation is slightly greater than a 500-year tide level.

Project features:

- Design Hurricane Tide = $14.8 \mathrm{ft}$ NGVD.

- East Branch Barrier:

o $2,840 \mathrm{ft}$ earth-filled dike with rock slope protection.

o Top elevation $=17.0 \mathrm{ft}$ NGVD.

\footnotetext{
1 From the New England District web page: https://rsgis.crrel.usace.army.mil/nae/pls/ nae/nae_web.nae_webmenu.displaymenu?menu=main, 1 December 2006.
} 
o $90 \mathrm{ft}$ wide navigation channel (flap gate invert $=-18.0 \mathrm{ft}$ NGVD).

o 100 cfs Interior runoff pump station (DA=1,200 acres).

o Bypass sluice gate 8ft x 8ft.

- West Branch Barrier:

o 1,440-ft concrete wall; $160 \mathrm{ft}$ sheet pile bulkhead wall; and 1,950-ft earth-filled dike.

o Top elevation $=17.0 \mathrm{ft}$ NGVD.

o 510 cfs Interior runoff pump station (DA=197acres).

- Westcott Cove Barrier:

o $4,200 \mathrm{ft}$ earth-filled dike.

o Top elevation $=18.0 \mathrm{ft} \mathrm{NGVD.}$

o 140 cfs \&50 cfs Interior runoff pump stations (DA=183 acres).

Ownership:

- All features (except navigation gate), Operated and Maintained by City of Stamford, CT - (203) 977-4681.

- Navigation Gate at East Branch Barrier Operated and Maintained by NAE Corps of Engineers.

Total Cost: $\$ 14,470,000$. 
Table 5. Stamford, CT, hurricane barrier.

\begin{tabular}{|c|c|c|}
\hline \multicolumn{3}{|c|}{ Mean Tide Data } \\
\hline Stage & Elev. (ft, NGVD) & \\
\hline Mean high water & 4.2 & \\
\hline Mean low water & -3.0 & \\
\hline Mean lower low water & -3.3 & \\
\hline Mean tide range & 7.2 & \\
\hline \multicolumn{3}{|c|}{ Water levels } \\
\hline Date & Elev (ft, NGVD) & Event \\
\hline \multicolumn{3}{|c|}{ Highest Since Project Construction } \\
\hline $12 / 1992$ & 10.1 & Northeaster \\
\hline $02 / 1978$ & 9.8 & Northeaster \\
\hline $11 / 1968$ & 9.4 & Storm \\
\hline $10 / 1996$ & 9.1 & Storm \\
\hline $02 / 1972$ & 9.0 & Storm \\
\hline $10 / 1980$ & 9.0 & Storm \\
\hline \multicolumn{3}{|c|}{ Highest Historic } \\
\hline 09/1938 & 11.0 & Great New England Hurricane \\
\hline $08 / 1954$ & 10.3 & Hurricane Carol \\
\hline $08 / 1893$ & 10.3 & Hurricane \\
\hline $09 / 1815$ & 10.2 & Hurricane \\
\hline $11 / 1950$ & 9.5 & Storm \\
\hline $11 / 1968$ & 9.4 & Storm \\
\hline $09 / 1944$ & 9.2 & Hurricane \\
\hline $11 / 1953$ & 9.2 & Storm \\
\hline $02 / 1960$ & 8.5 & Storm \\
\hline $\begin{array}{l}\text { NOTE: Interim damage } \\
7 \text { December 2006, an }\end{array}$ & $\begin{array}{l}\text { NGVD. Data fror } \\
\text { al Design Memo }\end{array}$ & $\begin{array}{l}\text { New England District web page, } \\
\text { m, July } 1962 .\end{array}$ \\
\hline
\end{tabular}

\section{Environmental factors}

There appear to be no post-construction environmental studies or reports. No information is available on siltation, circulation, or other conditions. 


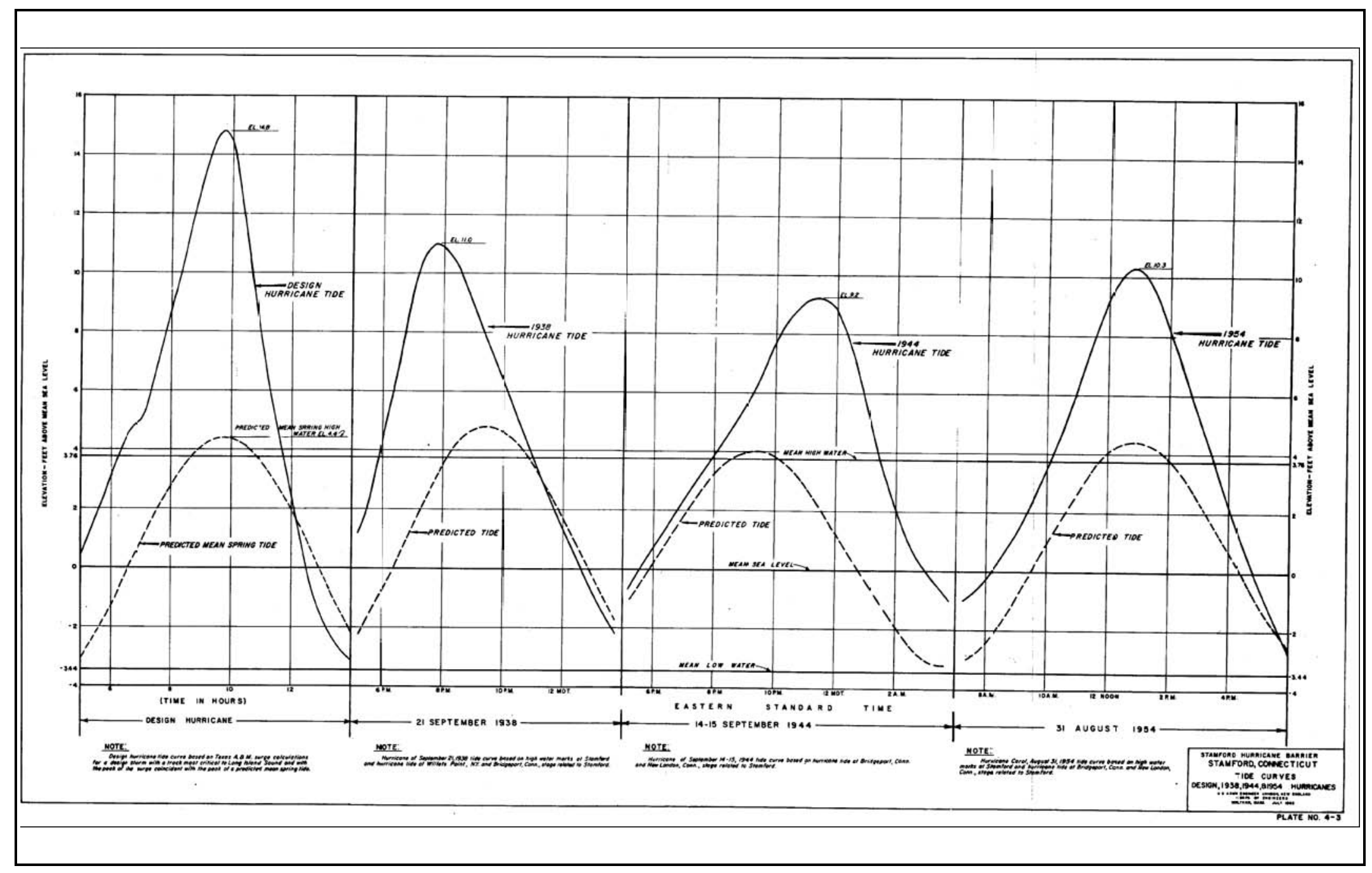

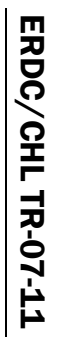

Figure 44. Stamford, CT, hurricane water levels. 


\section{Charles River Dam, Boston, MA}

\section{Project description}

The following description is an excerpt from the New England District web page. ${ }^{1}$ Figure 45 shows project elements.

The Charles River Dam Local Protection Project is located on the Charles River, between the Charlestown and North End sections of Boston.

The project provides flood protection to 2,440 acres of urban property along the banks of the Charles River. Much of this property is located in Boston, Brookline, Cambridge, and the Back Bay, and is valued in excess of $\$ 500$ million. The project also improves commercial and recreational navigation.

The state first constructed a dam on the Charles River in 1910 to prevent tidal flooding of lowlands, sewers, and drains along the lower reach of the Charles River and to create a pool, or basin, that would cover unsightly tidal flats. However, the growth of metropolitan Boston in the ensuing years resulted in the conversion of many open areas to development, increasing the amount of runoff into the Charles River Basin. Consequently, the dam became inadequate to meet flood control and navigation needs and could not be economically modified.

Preconstruction of the Charles River Dam Local Protection Project was initiated in November 1972 with the removal of the Warren Street Bridge. The major contract for construction of the dam was awarded in February 1974. The project was completed in May 1978 at a cost of $\$ 61.3$ million. Situated about 2,250 ft downstream of the old Charles River Dam, the new dam is operated and maintained by the Metropolitan District Commission.

\footnotetext{
1 From the New England District Water Resource web page: http://www.nae.usace.army.mil/ water/topic.asp?mytopic=Ippcharlesriverdam, 13 November 2006.
} 
The project consists of an earthfill and concrete dam with stone slope protection stretching between Boston and Charlestown. The dam is $400 \mathrm{ft}$ long with an elevation of $12.5 \mathrm{ft}$ above mean sea level. The connecting pumping station is $190 \mathrm{ft}$ long and $122 \mathrm{ft}$ high and contains six pumps. There are three navigation locks for commercial and recreational vessels. Two of the locks, for small recreational craft, each measure $200 \mathrm{ft}$ long, $22 \mathrm{ft}$ wide, and $8 \mathrm{ft}$ deep. The third lock, $40 \mathrm{ft}$ wide, $300 \mathrm{ft}$ long, and $17 \mathrm{ft}$ deep, accommodates commercial vessels, large recreational boats, and the overflow of small craft during peak days.

The project also incorporates a boat facility for the Metropolitan District Commission Police, a small plaza park, a visitors' center, and a fish ladder that helps restore fish migration to the river. The growth of metropolitan Boston and urban land use greatly decreased the amount of fish spawning in the upper reaches of the river. The ladder provides a passage for several species of fish, principally shad, alewife, smelt, and blue-back herring, to migrate up the Charles River and spawn in fresh water.

The Charles River Dam has been honored with several architectural awards, most notably a Presidential Award for Design Excellence. 


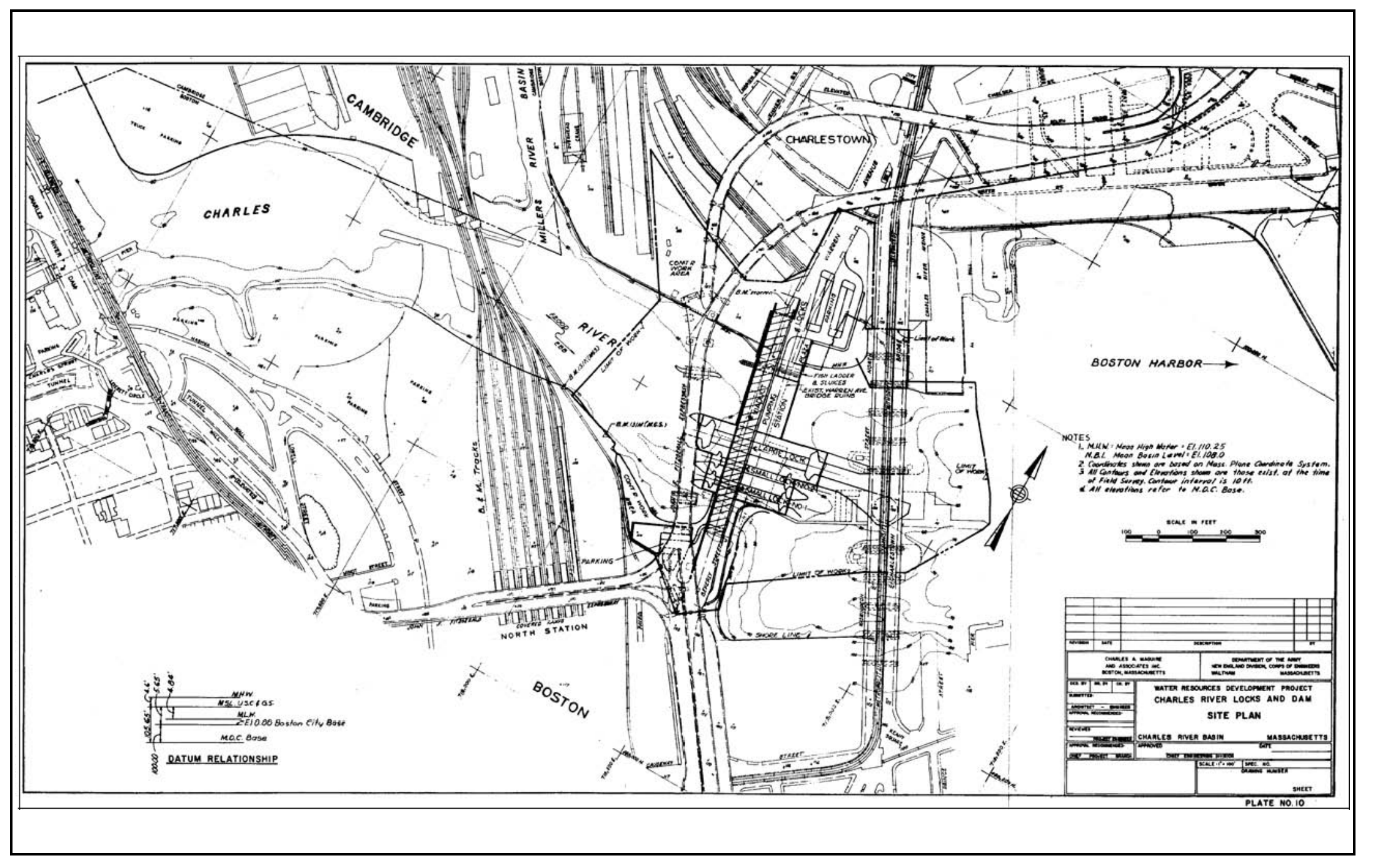

Figure 45. Charles River, Boston, dam and hurricane protection barrier. 


\section{Design and details}

The following design summary is from the New England District web page. ${ }^{1}$ Table 6 lists historic water levels and Figure 46 plots storm and hurricane water levels.

Project Use: Flood Control, Recreation and Navigation. Operate the dam to keep basin level below start of damage of $4.35 \mathrm{ft} \mathrm{NGVD}$ by using pumps and sluice gates to pass inflows against high tide levels.

Project Personnel: Owned, Operated and Maintained by the Metropolitan District Commission (MDC) of Boston (617) 727-0488 (now merged into the Massachusetts Department of Conservation and Recreation).

Drainage Area: 309 sq mi.

Normal Pool: 2.35ft NGVD (704 acres; 10,540 acreft).

Dam:

- Type: Rolled earth fill, rock slope protection, sheet piling

- Length: $160 \mathrm{ft}$.

- Top Elev: $12.35 \mathrm{ft}$ NGVD.

- Start Damage: $4.35 \mathrm{ft}$ NGVD.

- CONTROL WORKS.

- Pumps: 6 @ 1,400 cfs against $9 \mathrm{ft}$ head.

- - Sluice Gates: 1-High Level $8 \mathrm{ft}$ x $10 \mathrm{ft}$.

o Upstream invert $=-10.15 \mathrm{ft}$ NGVD.

o 1 -Low Level $8 \mathrm{ft} \times 10 \mathrm{ft}$.

o Upstream invert $=-18.65 \mathrm{ft}$ NGVD.

- NAVIGATION LOCKS.

- Large: $1 @ 40 \mathrm{ft}$ widex $300 \mathrm{ft}$ long.

- Upstream invert =-14.65 ft NGVD.

- Small: 2 @ $25 \mathrm{ft}$ widex $200 \mathrm{ft}$ long.

- Upstream invert =-5.65 ft NGVD.

Total Cost: $\$ 61,216,000$.

Placed In Operation: May 1978.

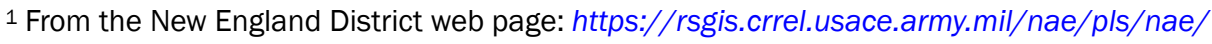
nae_web.nae_webmenu.displaymenu?menu=main, 1 December 2006.
} 
Table 6. Charles River, Boston, MA, dam and local protection project.

\begin{tabular}{|l|l|l|}
\hline \multicolumn{3}{|c|}{ Mean Tide Data ${ }^{1}$} \\
\hline Stage & Elev. (ft, NGVD) & Elev. (ft, MDC datum) \\
\hline Mean high water & 4.55 & 110.2 \\
\hline Mean low water & -4.85 & 100.8 \\
\hline Ave. spring tide high & 5.25 & 110.9 \\
\hline Ave. spring tide low & -5.65 & 100.0 \\
\hline Spring tide range & $13.0+$ & \\
\hline Design tide & 7.35 & 113.0 \\
\hline Date & Elev. (ft, MDC) & Elev. (ft, MSL) \\
\hline \multicolumn{3}{|l|}{ Highest Tide Since Construction, Boston Harbor (1983-2001 epoch) ${ }^{2}$} \\
\hline 02/07/1978 & 115.5 & 9.89 \\
\hline \multicolumn{3}{|l|}{ Highest Historic Tide Heights, Boston Harbor (adj. to 1970) ${ }^{1}$} \\
\hline 4/16/1951 & 116.6 & 11.0 \\
\hline 2/24/1723 & 116.3 & 10.7 \\
\hline 12/26/1909 & 116.2 & 10.6 \\
\hline 4/12/1786 & 115.8 & 10.2 \\
\hline 12/15/1839 & 115.8 & 10.2 \\
\hline 12/27/1839 & 115.8 & 10.2 \\
\hline 4/18/1852 & 115.7 & 10.1 \\
\hline 11/27/1898 & 115.7 & 10.1 \\
\hline 12/29/1959 & 115.0 & 9.4 \\
\hline $\begin{array}{l}\text { NOTE: } \\
\text { Metropolitan District Commission (MDC) local datum: 0.0 ft NGVD or Mean Sea Level } \\
\text { Datum = 105.65 ft MDC. } \\
\text { Data from the New England District web page, 18 December } 2006, \text { and General Design } \\
\text { Memorandum, May 1971. } \\
\text { 2 From NOAA: www.tidesandcurrents.noaa.gov. }\end{array}$ \\
\hline
\end{tabular}




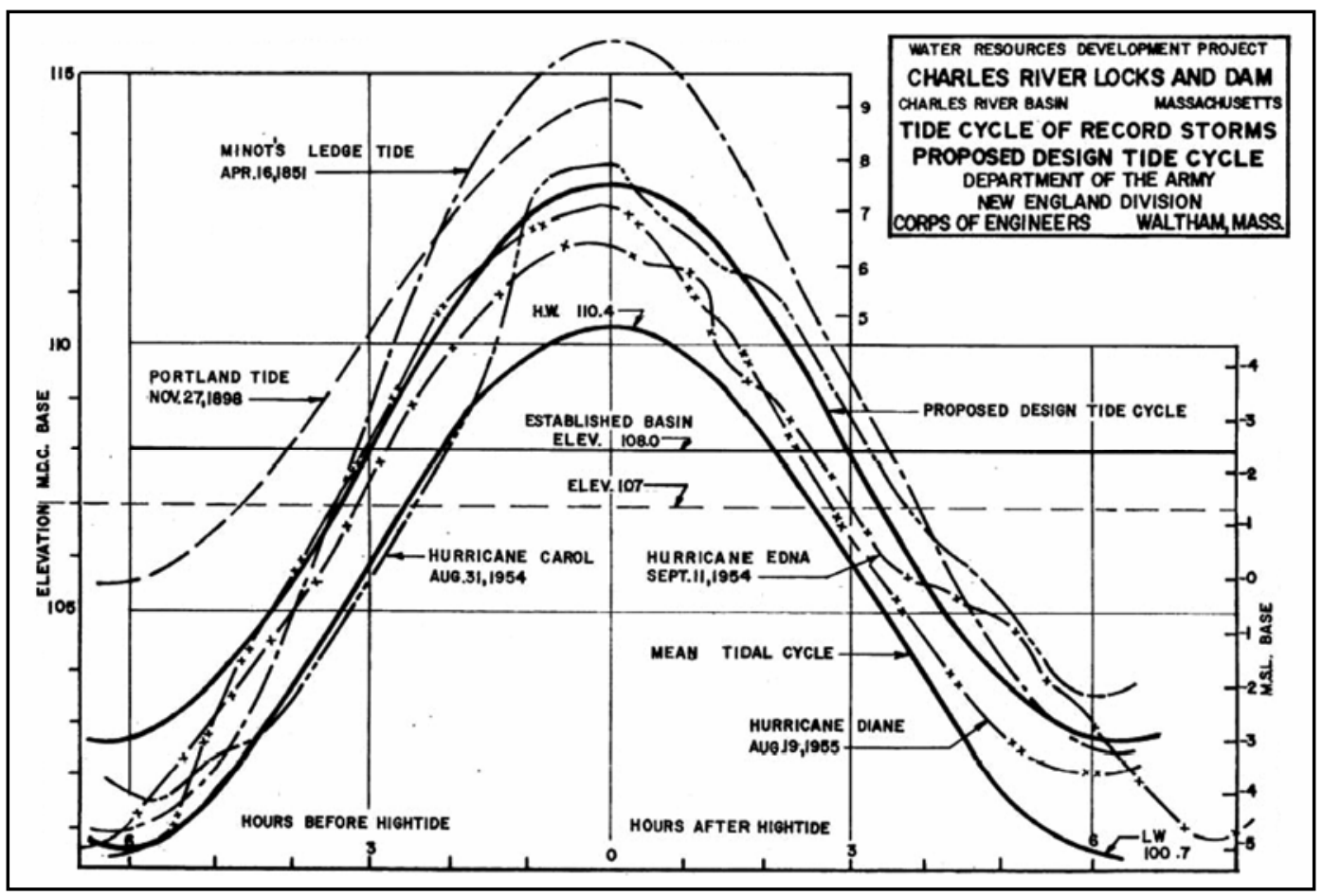

Figure 46. Charles River dam tide cycle of historical storms. Elevations on left axis are the Metropolitan District Commission local datum. This plot was drawn before Blizzard of 1978.

The Charles River Dam is a more multi-function project than the other hurricane barriers. Not only was it designed to protect against unusually high tide or surge in Boston Harbor but also to maintain a restricted range of water level in the Charles River Basin. The Basin between Boston and Cambridge was formerly an expanse of mudflats that were exposed twice daily and renowned for mosquitoes and nasty aromas in summer. The original 1910 dam converted the basin into an agreeable fresh-water body, along which fashionable homes, a landscaped esplanade, and institutions of higher learning were located (Whitehill 1968). Little of the original dam can be seen because a busy highway crosses it and the Museum of Science was built on the dam in 1950 (Figure 47).

The new dam was completed in 1978 about 0.6 mile east or downstream of the older one, at the site of the former Warren Avenue Bridge. The project consists of a rock-faced dam, locks, and a pumphouse (Figures 48-51). The pumps are diesel-powered and independent of the municipal power grid (Figure 52). 


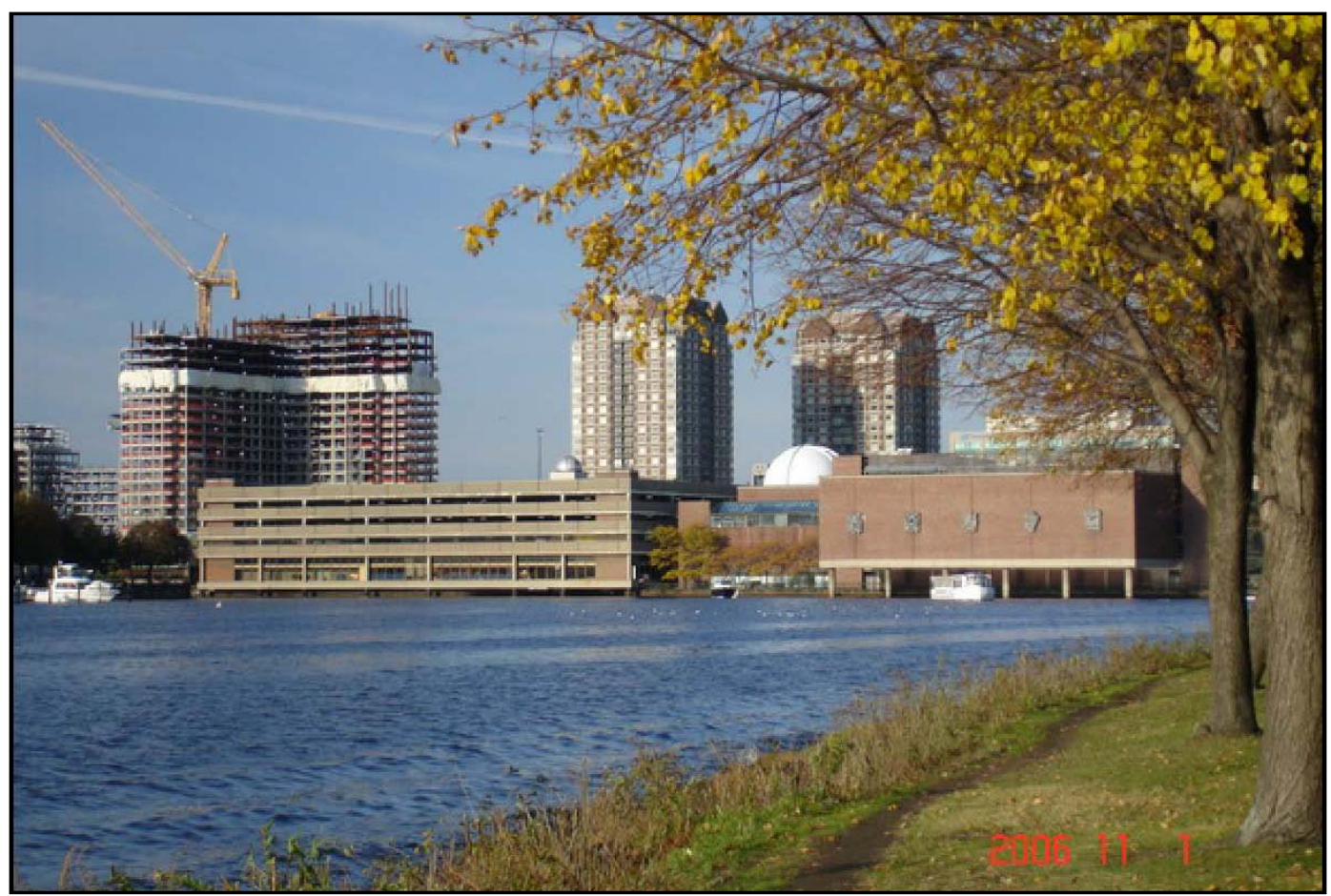

Figure 47. Original 1910 Charles River Dam, on which Boston Museum of Science was built. Charles River Basin is in foreground.

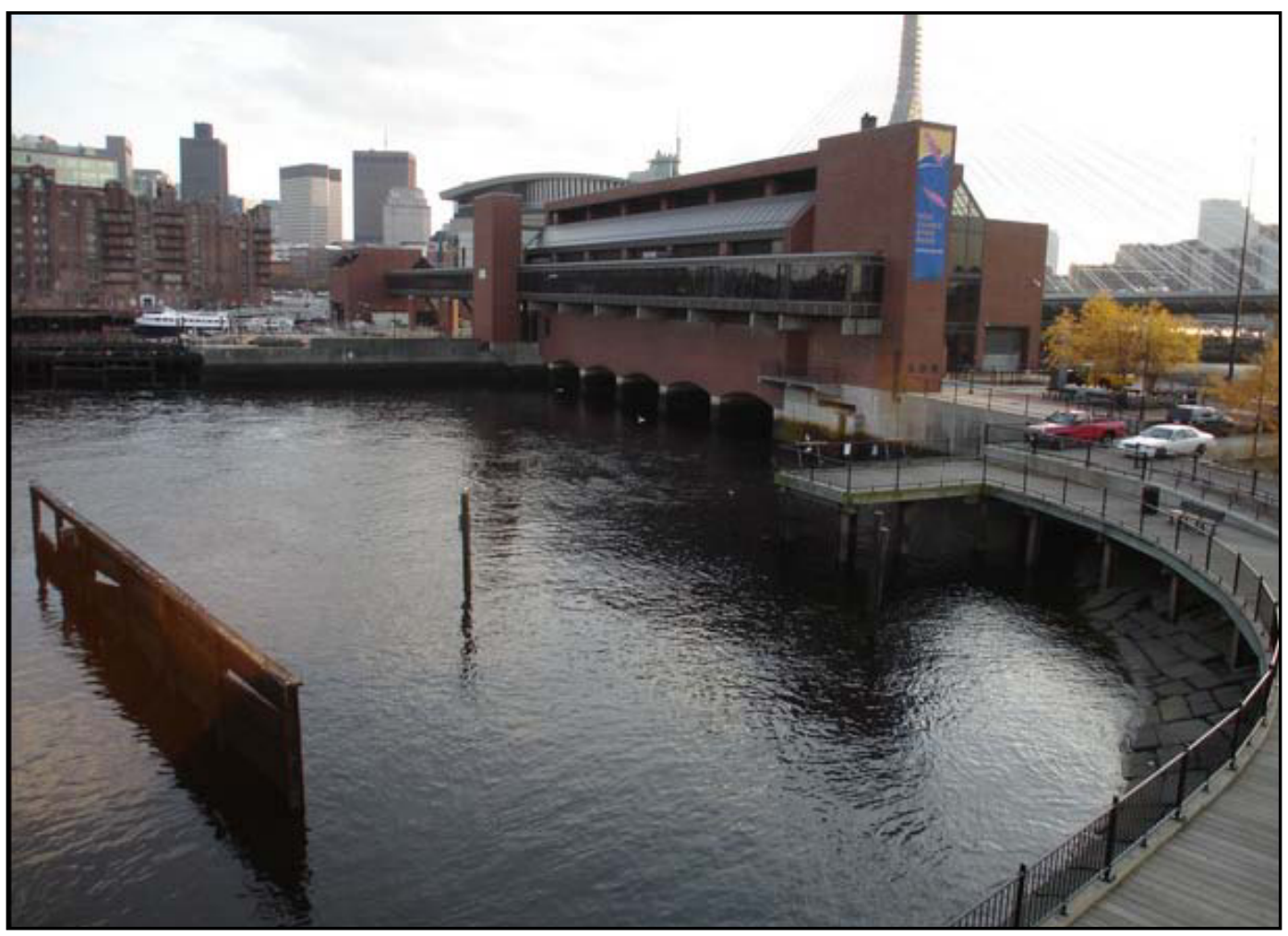

Figure 48. Charles River Dam from Charleston Bridge (Route 99), view looking south, 1 November 2006. Brick structure contains pumps. Water in foreground is tidal. 


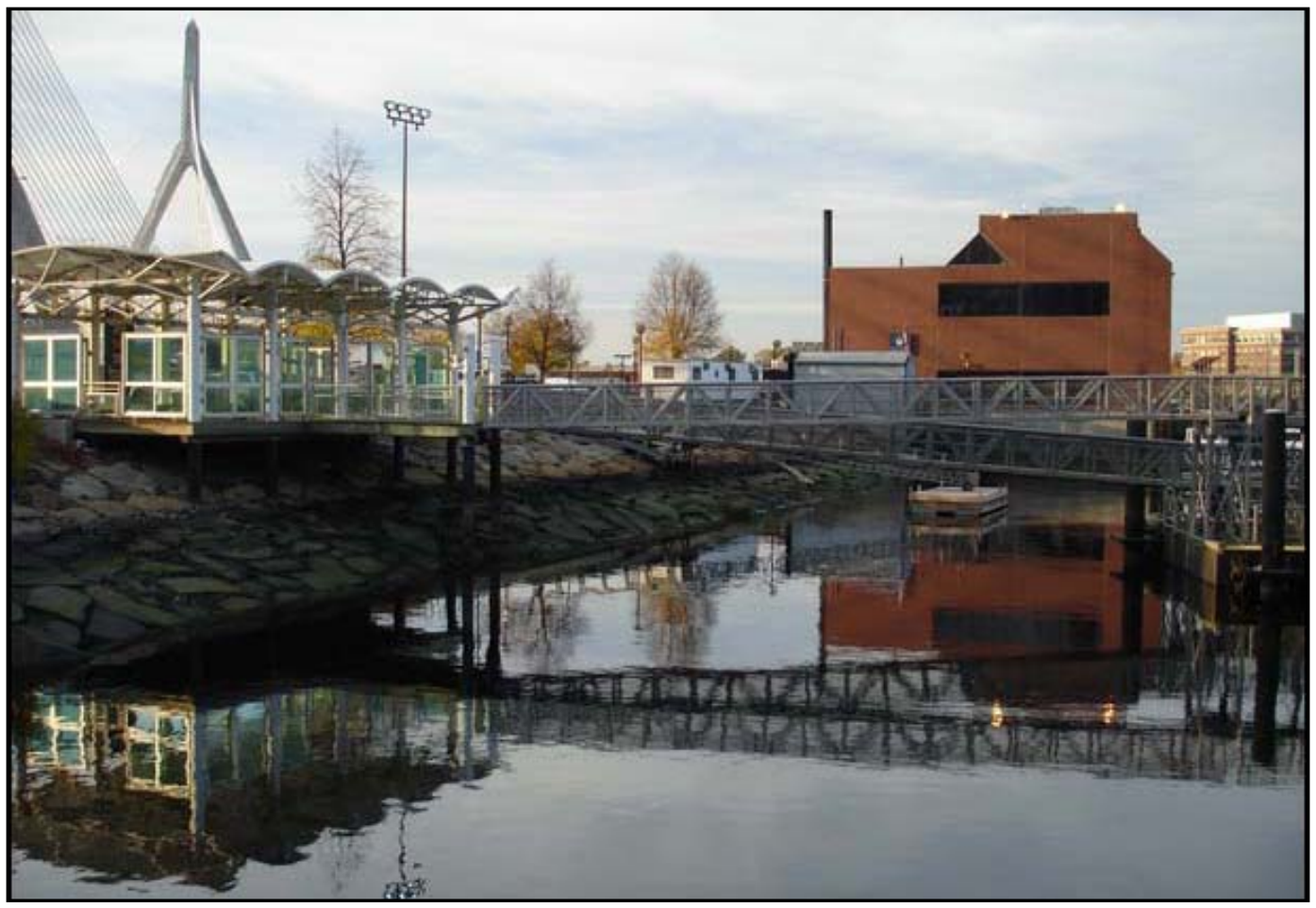

Figure 49. Charles River Dam harbor side, view from Boston shore looking NW, 1 November 2006.

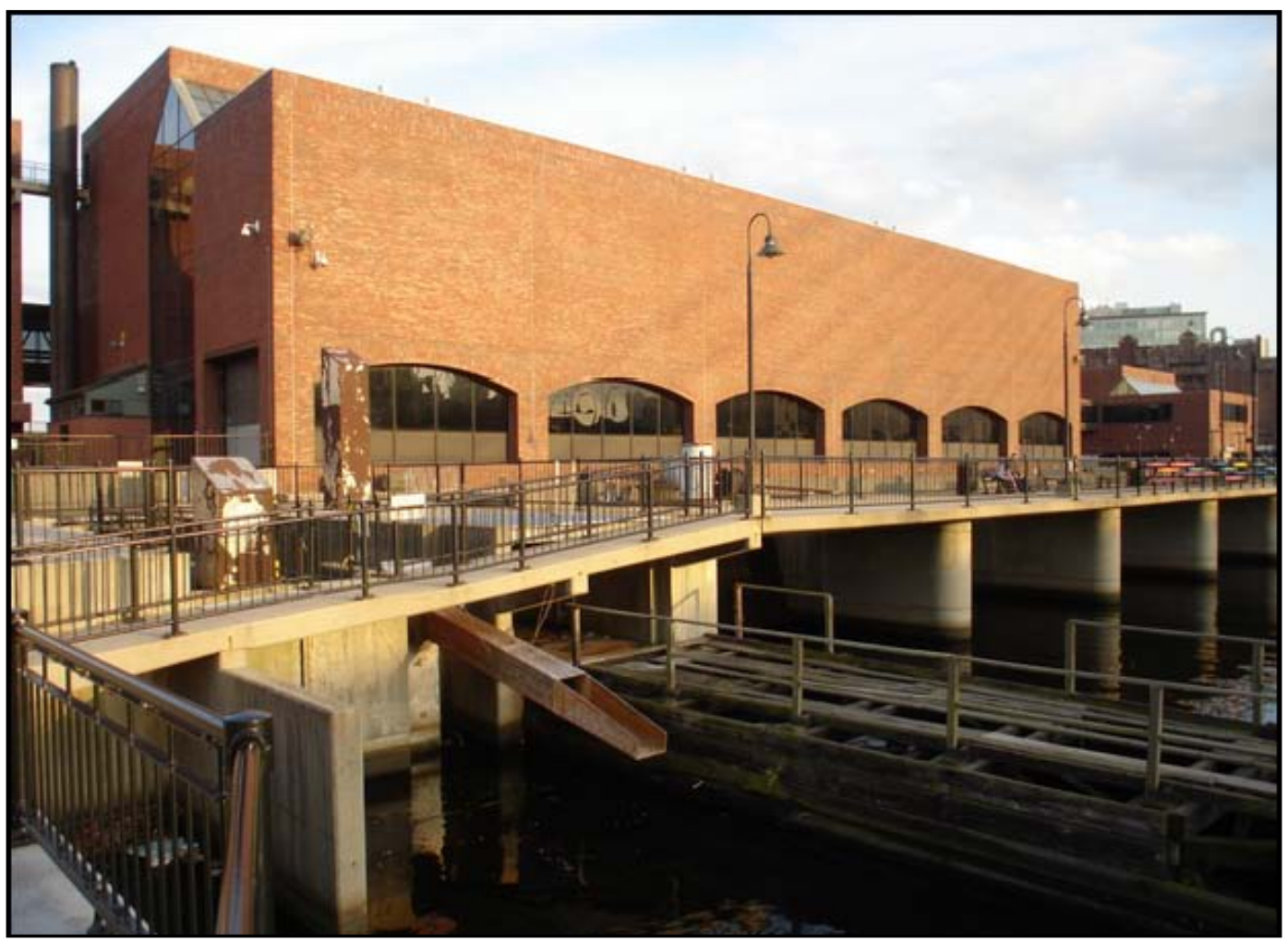

Figure 50. West side of Charles River Dam pump house, 1 November 2006. 


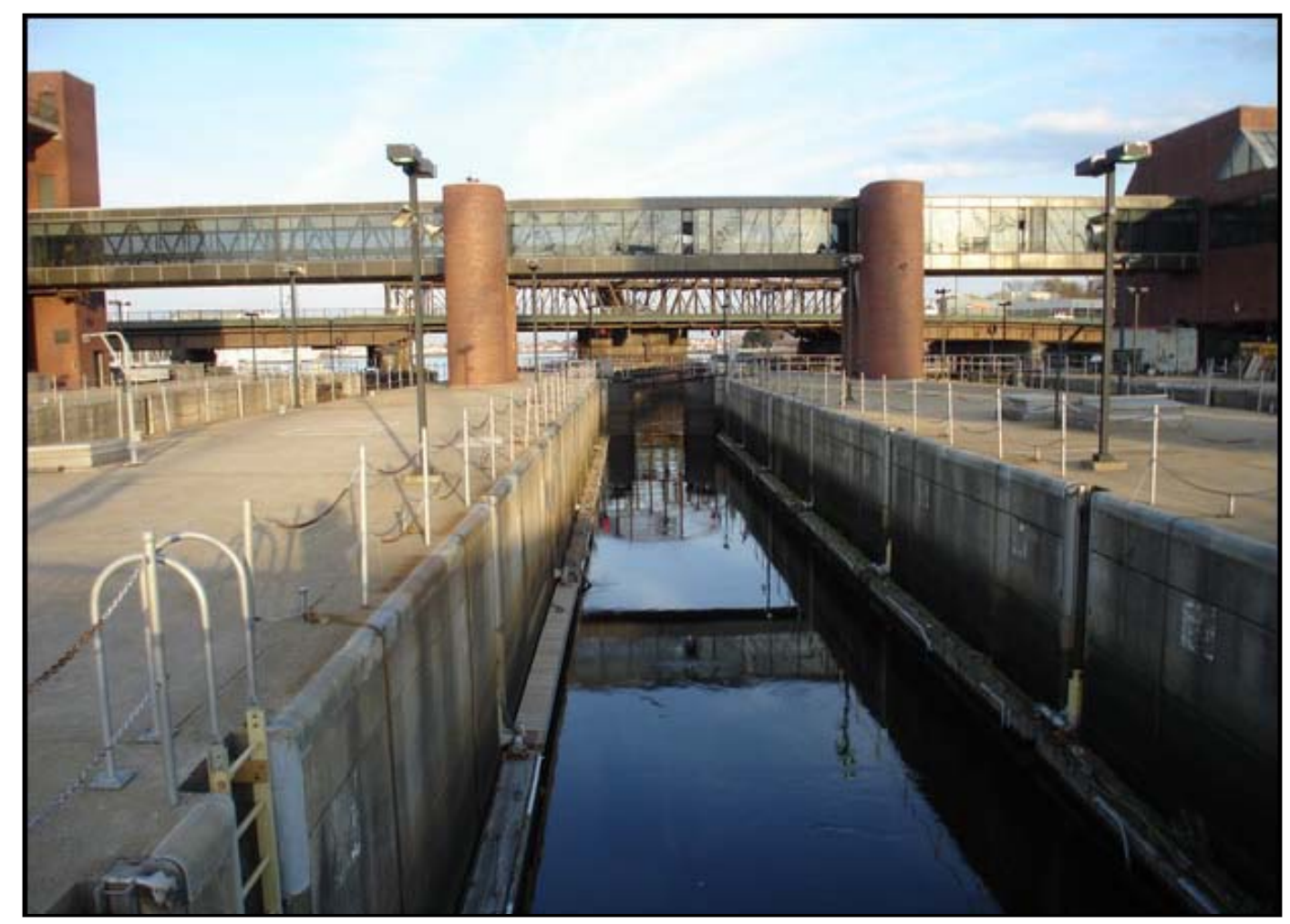

Figure 51. Navigation lock, Charles River Dam, view looking east towards Boston Harbor, 1 November 2006.

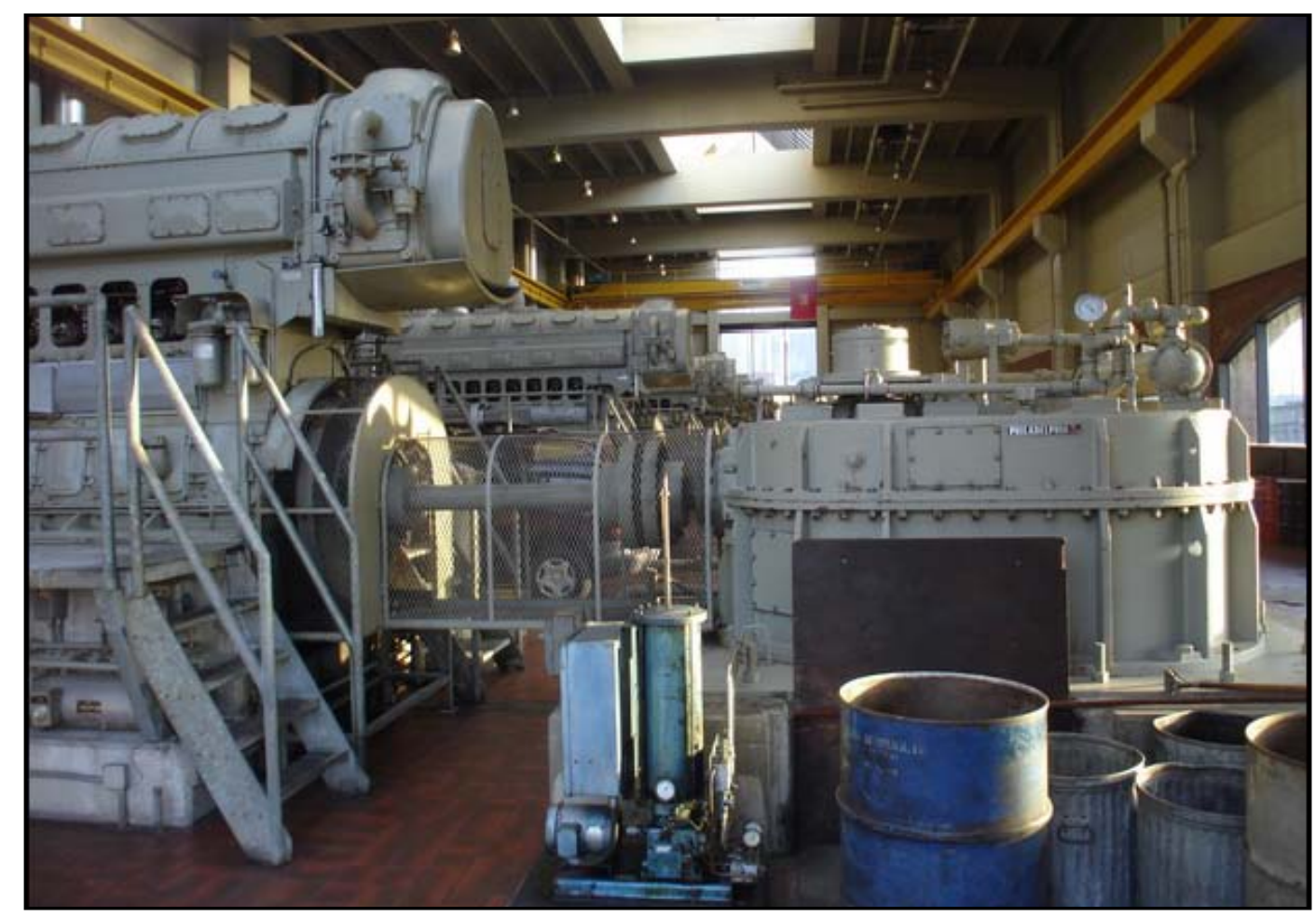

Figure 52. Diesel engines and pumps in Charles River Dam, 1 November 2006. 
Property in the Charles River Basin is highly sensitive to changes in water level and the elevation must be kept between $107.0 \mathrm{ft}$ and $109.9 \mathrm{ft}$ (MDC datum). ${ }^{1}$ At $107 \mathrm{ft}$, boating problems occur, while at $109.7 \mathrm{ft}$, low areas along the shore begin to flood. At spring tide, Boston harbor water is higher than the Charles River level. The Charles River Dam is also unusual in that high runoff into the basin cannot be controlled by the six pumps alone. The gates on the sluices must be manipulated in addition to using the pumps, and the water in the basin must be lowered before a major storm in anticipation of the inflow of runoff and rainfall. The pumps are in good condition and the impellers have not displayed signs of brittleness. ${ }^{1}$

The water level of record in Boston Harbor occurred during the Blizzard of 1978. Much of New England was enveloped in blizzard conditions, causing snow drifts of $15 \mathrm{ft}$ in the Boston suburbs. Winds generated a powerful tidal surge, which led to serious coastal flooding and beach erosion from NewJ ersey to Maine. The longevity of the storm led to four successive flooding high tides, which compounded the damage to beaches and property. In Massachusetts, 99 people were killed and thousands of houses and businesses were destroyed or heavily damaged, with damage estimates exceeding $\$ 2.3$ billion (in 1998 dollars). ${ }^{2}$ Although the Charles River project had not been formally completed, the pumps and other equipment were operated and helped prevent significant flood damage in the basin.

\section{Environmental factors}

By the time the Charles River Dam was built in the mid-late 1970s, far more extensive environmental studies were required than for the earlier projects in Providence, New Bedford, and Connecticut. A final environmental statement was prepared (New England Division 1973). The Charles River Dam was designed to not only prevent salt water from entering the basin but also slowly flush salt water out.

The dam contained an innovative fish ladder, designed with assistance from fisheries experts in the northwest (North Pacific Division 1977). The ladder has not functioned as planned for unknown reasons, but the other elements of the project have been a stellar success. Aelwives (Alosa pseudoharengus), blueback herring (Alosa aestivalis), American shad

\footnotetext{
1 Mr. James Law, New England District, personal communication, 15 December 2006.

2 Massachusetts Coastal Zone Management web page: $h$ ttp://www.mass.gov/czm/blizzard78.htm, 20 December 2006. Some damage estimates are much lower, in the $\$ 500$ million range.
} 
(Alosa sapidissima), and Atlantic rainbow smelt (Osmerus mordax mordax) simply pass through the locks with boats, and if large numbers of fish enter the locks when no boats are present, the operators lock them through (Hall 1986). On 1 November 2006, the author saw many cormorants swimming in the harbor next to the dam, attesting to the abundance of fish. 


\section{Raritan Bay and Sandy Hook Bay Beach Erosion and Hurricane Project, NJ}

\section{Project description}

The following description is an excerpt from an unpublished New York District report. ${ }^{1}$ Figure 53 shows project elements.

The constructed shore front section of the project includes the shoreline community of Laurence Harbor located in Old Bridge Township, and Keansburg and East Keansburg (more recently renamed North Middletown) located in Middletown Township. Old Bridge Township includes the nearly 0.6 miles of coastline between Cheesequake Creek to the west and Whale Creek to the east. Keansburg and East Keansburg include approximately 2.7 miles of coastline between Thorn's Creek to the west and Pews Creek to the east.

\section{Design and details}

The beach erosion control and hurricane protection project for Raritan Bay and Sandy Hook Bay, NJ , was authorized by the Flood Control Act of 1962, in accordance with House Document No. 464, 87th Congress, 2nd Session. In the authorizing document, the Chief of Engineers, after due consideration of the recommendations of the reporting offices and the findings of the Board of Engineers for Rivers and Harbors, recommended project provisions to the Secretary of the Army. These included improvements for the prevention of beach erosion and hurricane damages along a 21-mile portion of the Raritan Bay and Sandy Hook Bay shoreline which provided for the following:

1. Morgan Beach (Old Bridge Township). A beach berm to be constructed at a height of $15.0 \mathrm{ft}$ MSL (mean sea level) $25 \mathrm{ft}$ wide with a slope of $1 \mathrm{~V}: 20 \mathrm{H}$ and 2,300 $\mathrm{ft}$ long. A levee was also to be constructed adjacent to New J ersey Route 35. This levee was to be built at a height of $15.0 \mathrm{ft} \mathrm{MSL,} \mathrm{width}$ $25 \mathrm{ft}$ and $900 \mathrm{ft}$ long.

\footnotetext{
${ }^{1}$ Ms. Christina Rasmussen, New York District, personal communication, 13 February 2007.
} 
2. Laurence Harbor (Old Bridge Township). A beach berm to be constructed at a height of $10 \mathrm{ft} \mathrm{MSL}$, width $25 \mathrm{ft}$ with a slope of $1 \mathrm{~V}: 20 \mathrm{H}$ and length of $3,800 \mathrm{ft}$.

3. Seidler Beach (Old Bridge Township). A beach berm to be constructed at a height of $10 \mathrm{ft}$ MSL, with a slope of $1 \mathrm{~V}: 20 \mathrm{H}$, width $100 \mathrm{ft}$ and length of $2,200 \mathrm{ft}$.

4. Knollcroft (Old Bridge Township). A beach berm to be constructed at a height of 10.0 MSL, width $25 \mathrm{ft}$ with a slope of $\mathrm{VV}: 20 \mathrm{H}$ and length of $2,850 \mathrm{ft}$.

5. Union Beach. Beach fill was to be placed at a height of $5.5 \mathrm{ft} \mathrm{MSL} \mathrm{and}$ $100 \mathrm{ft}$ wide with a slope of $1 \mathrm{~V}: 20 \mathrm{H}$ along 0.6 mile of shoreline.

6. Keansburg and East Keansburg. A beach berm to be constructed at a height of $15.0 \mathrm{ft}$ M.S.L., width $25 \mathrm{ft}$ with a slope of $1 \mathrm{~V}: 20 \mathrm{H}$ and length of $14,400 \mathrm{ft}$. Two closure levees, both in excess of 6,000 ft in length were to be constructed, one at the west side of Thorns Creek and the other at the west side of Pews Creek. A closure gate and pumping station were to be constructed at Waackaack Creek. Three stone groins, each $285 \mathrm{ft}$ in length were to be constructed at Point Comfort.

7. Construction of the authorized project for Old Bridge Township (Morgan Beach, Laurence Harbor, Seidler Beach, and Knollcroft) was initiated in 1965 and completed in 1966. Construction of the shoreline portion of the authorized project for Keansburg and East Keansburg was initiated in 1968 and completed in 1969. During construction, a total of 3.4 million cu yd of sand fill dredged from several offshore borrow areas was placed on the project area.

8. Construction of the closure portion (levee and closure gate) of the authorized project for Old Bridge Township was initiated and completed in 1966.

9. Construction of the closure portion (levees, closure gate and pumping station) of the authorized project for Keansburg and East Keansburg was initiated in 1970 and completed in 1973.

10. Cliffwood Beach and Union Beach were the only portions of the authorized project not constructed. These unconstructed portions of the Raritan Bay and Sandy Hook Bay project were deauthorized in J anuary 1990, as noted in the Federal Register. 


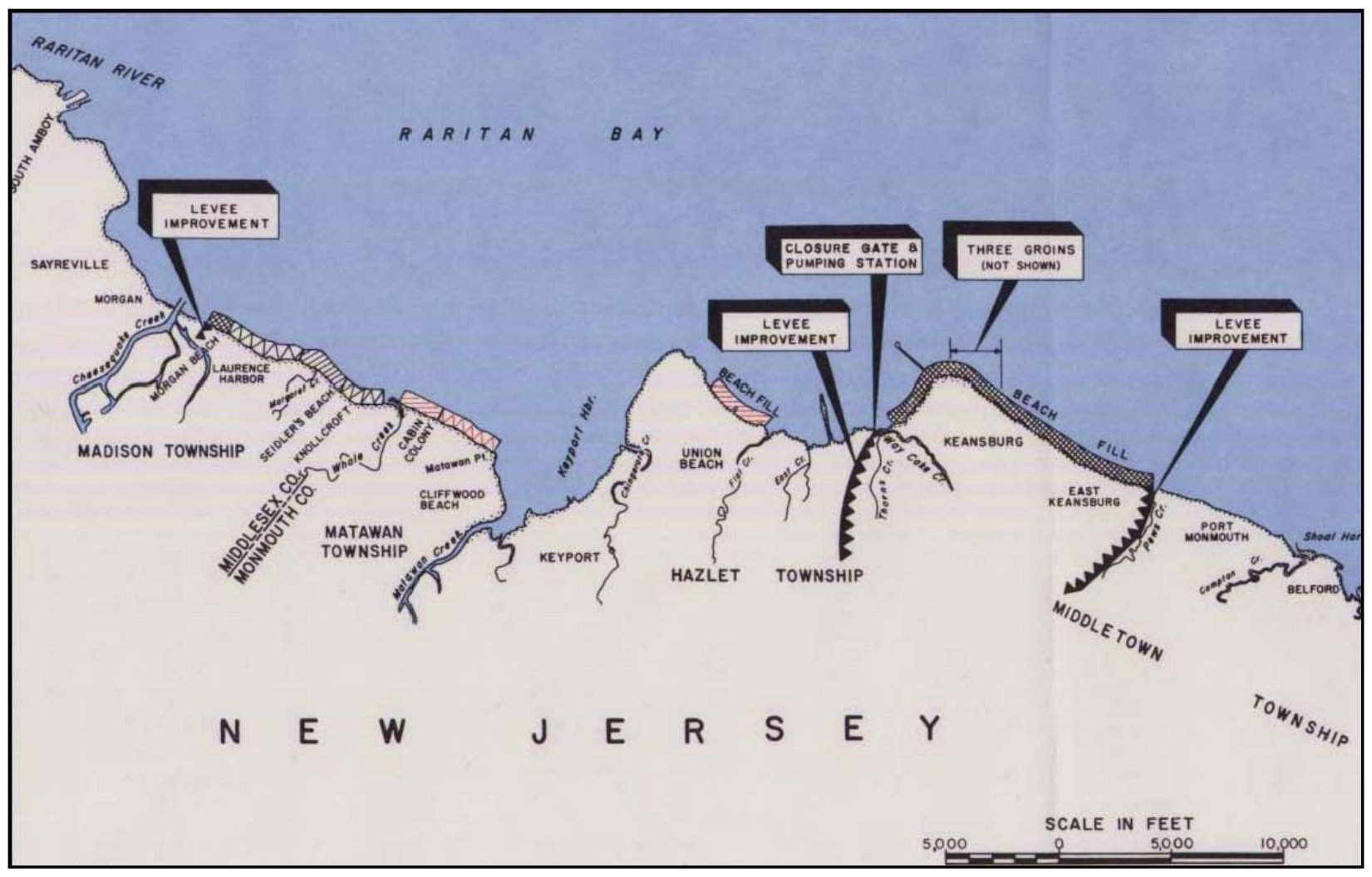

Figure 53. Raritan Bay project elements (from USACE digital project notebook). Sawtooth pattern represents levees. Fill and Levees in Matawan Township and fill in Union Beach (in red) were never built. North is to top.

The following water elevation data from the Operations and Maintenance manual refers to the Authorized 1957 Design Event:

1. Design Stage. The design stage used in the original Keansburg and Laurence Harbor beach fill cross-sections consisted of the maximumrecorded surge height during the 25 November 1950 northeaster superimposed on a normal high tide (which was $2.5 \mathrm{ft}$ MSL in 1950). The maximum surge recorded at Perth Amboy was $10.4 \mathrm{ft}$., giving a design stage of $+12.9 \mathrm{ft}$ MSL. The measurement was near land, and therefore was assumed to include wave up rush (setup).

2. Design Wave. A design wave of $9 \mathrm{ft}$ at the toe of the fill was used for the original design.

3. Design Wave Runup. A design wave runup of $2 \mathrm{ft}$ was used based on the $9 \mathrm{ft}$ design wave, utilizing the composite slope method.

This area experienced only minor flooding during the 1938 hurricane, but the 1944 hurricane caused widespread damage along the New J ersey shore. The hurricane caused a storm surge of up to $9.6 \mathrm{ft}$ and waves of up 
to $40 \mathrm{ft}$ in height along the Atlantic shore, resulting in widespread flooding. In addition, winds gusting to $125 \mathrm{mph}$ destroyed hundreds of homes and damaged thousands, while the waves washed away fishing piers and boardwalks. At Keyport, all boat docks and piers were destroyed, and in the vicinity of Union Beach, flood waters reached 500 to 1,000 ft inshore (New York District 1960). The extreme storm frequency curve was prepared in 1960 and predates the Ash Wednesday storm of 1962 (Figure 53). Oddly, the frequency curve in the 1964 GDM is identical to the one in the 1960 survey report and apparently was not changed to reflect the Ash Wednesday storm.

The original design, as outlined in the general design memorandum (New York District 1963, 1964), was for both beach restoration and hurricane protection. The project was modified over time. The shore protection at the west end of Madison Township (now Old Bridge Township) was not built. In east Madison Township, the cabin colony of beach cottages was destroyed before construction commenced, thereby negating the need for the beach fill and levee there. The beach fill at Union Beach was also not built.

The Lawrence Harbor levee and beach fill was completed in October 1966. The Keansburg and East Keansburg beach fill was completed in December 1969, and the adjoining levee in J une 1973. ${ }^{1}$ The project also included infrastructure improvements such as raising some streets and installing flood gates at roads and railroads. Also included in the 1973 project was the Bayshore Floodgate, which is located at the junction of Waackaack and Thorns Creeks (Figures 54 and 55). The facility consists of a floodgate and pump station at the base of the Raritan Bay as well as a series of levees and dikes that hold back floodwaters during storms. "The station is equipped with four, vertical shaft, axial flow pumps, and two centrifugal type sump pumps. Each flood pump is rated at not less than 55,000 gpm or $113 \mathrm{cfs}$ against a total dynamic head of $5 \mathrm{ft}$, and not less than 38,600 gpm or 86 cfs against a total dynamic head of $15 \mathrm{ft} .{ }^{\prime 2}$ The New J ersey Department of Environmental Protection Bureau of Coastal Engineering operates and maintains the facility on a 24-hr basis. The gates are closed over 100 times a year, for every spring tide and whenever the tide stage in Raritan Bay reaches $4.5 \mathrm{ft}$ above MSL.

\footnotetext{
${ }^{1}$ Ms. Christina Rasmussen, New York District, personal communication, 8 January 2007.

2 O\&M manual, pp 40-41, U.S. Army Engineer District, New York.
} 
The USACE project has performed as designed. The beach has not been renourished since construction. Although the beach has suffered erosion over three decades, the dune has not failed. Federal renourishment was not part of the original project design, and the local sponsors have been unable or unwilling to fund renourishment. Also, interior drainage from streets is now a serious problem after heavy rains because of increased urbanization.

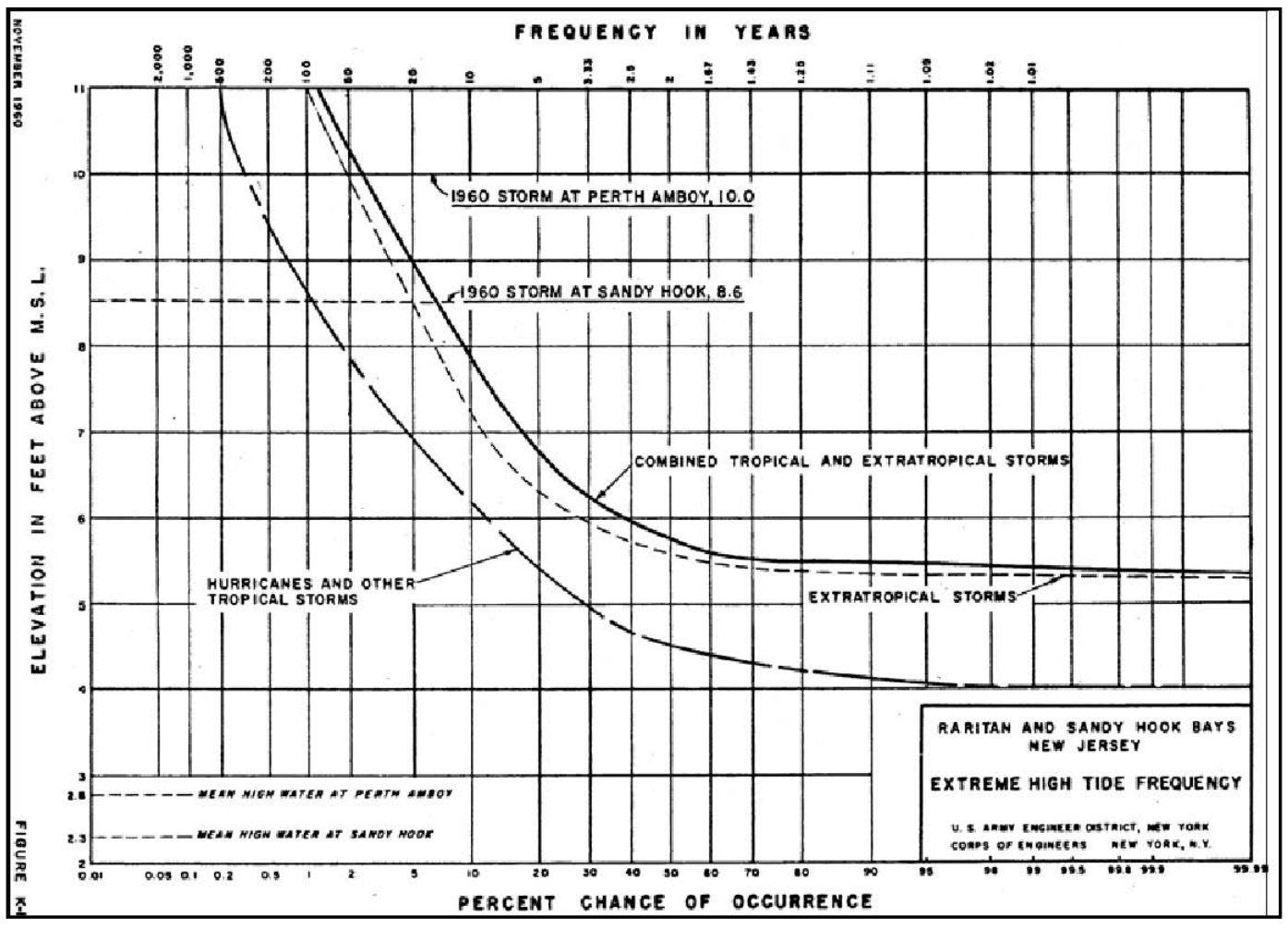

Figure 54. Storm frequency curve for Raritan Bay (from interim hurricane study, New York District 1960). Design elevation of surge added to high tide was $+12.9 \mathrm{ft}$ MSL. 


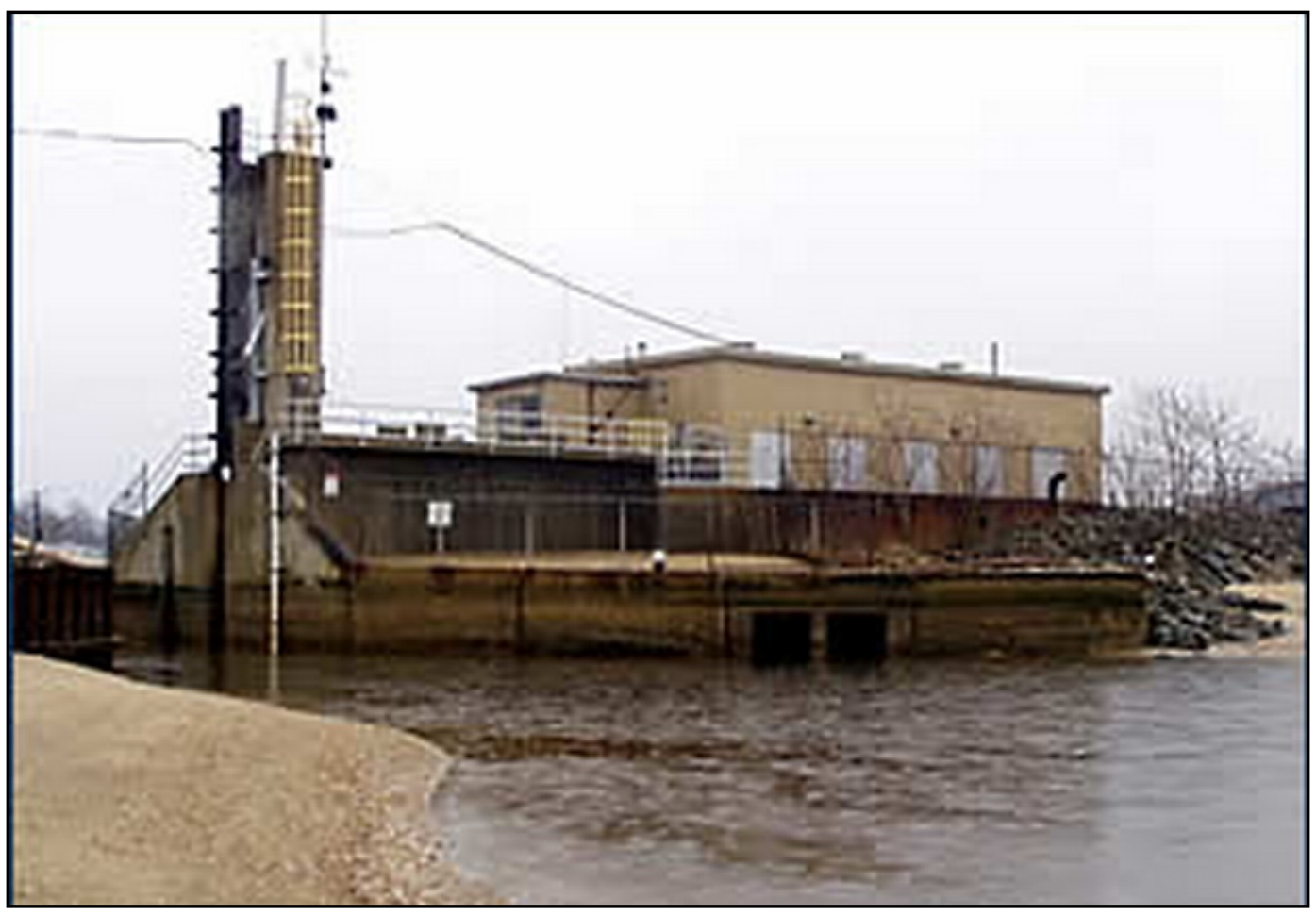

Figure 55. Bayshore floodgate and pump station, at junction of Waackaach and Thorns Creeks. From New Jersey Deparatment of Environmental Protection (http://www.state.nj.us/dep/shoreprotection/bayshore.htm, 8 January 2007).

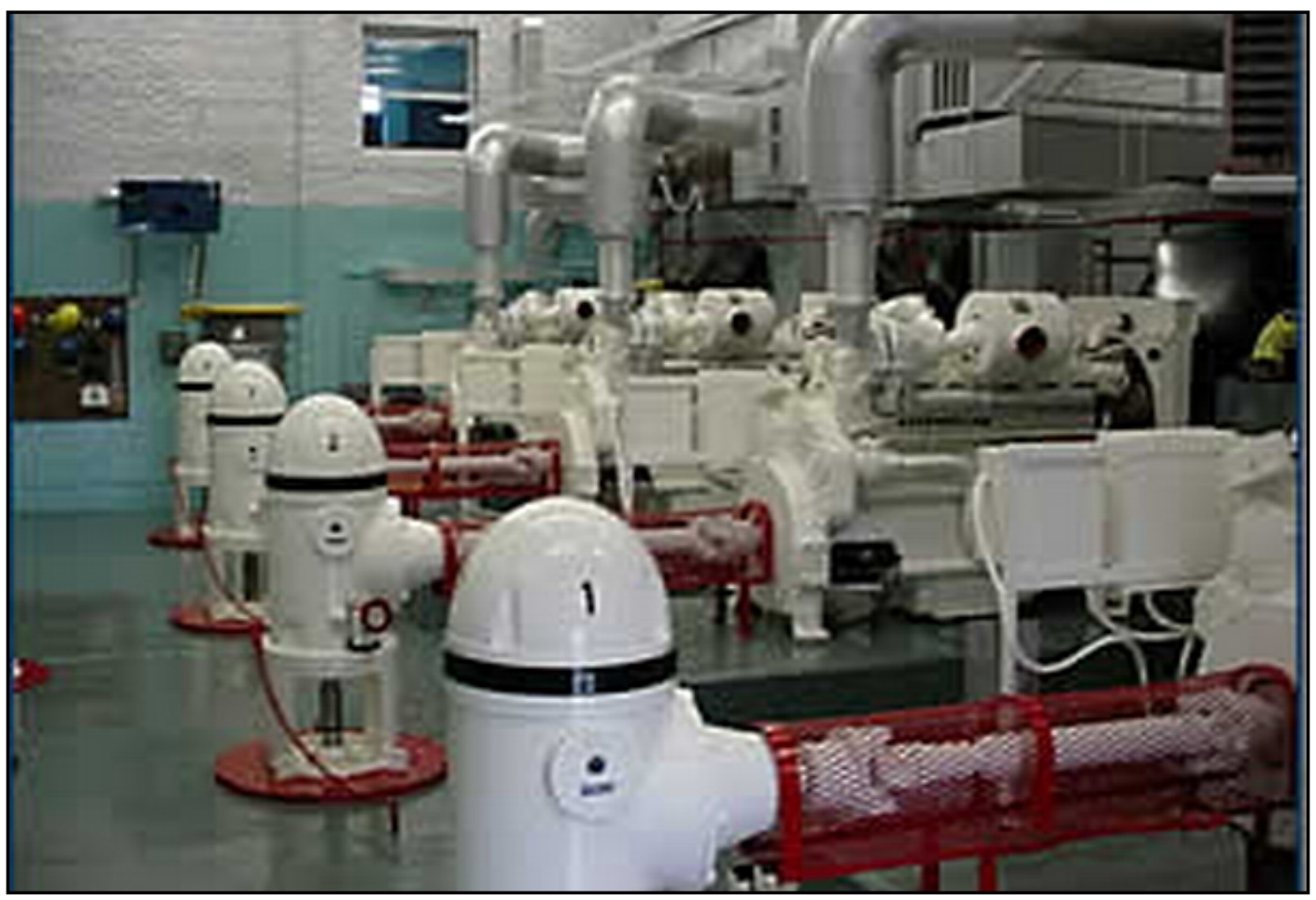

Figure 56. Pump house at Bayshore Floodgate Facility. From NJ Dep (http://www.state.nj/dep/shoreprotection/bayshore.htm, 8 January 2007). 


\section{Conclusions}

The New England storm surge barriers were delayed almost three decades from the time of the first disastrous 20th century hurricane in 1938 to their completion. Some of this delay was caused by geopolitical factors (World War II and possibly the beginning of the Cold War), but much of this time was spent conducting studies, awaiting legislative authority, and securing local cooperation. It took a second major storm, Hurricane Carol in 1954, to spur Congress into authorizing a major investigation of hurricane damage potential. Also, and possibly just as important, by the mid-20th century, Americans had changed their attitude toward the role of the state. The U.S. Government had brought us victorious through World War II, and more citizens than ever before felt their government should also play an active role in mitigating and protecting against natural disasters. Over 20 legislative acts in the 1950s through the 1970s authorized an increased Federal role in shore protection (Morang and Chesnutt 2004).

Table 7 summarizes design storm elevations and features of the projects.

It is difficult to assess the dollar value of the protection afforded by the New England and New J ersey hurricane barriers. The cost analyses from the 1950s show values in the low tens of millions, but these numbers are irrelevant now. Five decades have passed, and the Northeast is much more extensively developed. Not only is the coastal zone more densely inhabited, but the value of homes and industries is immensely greater (the $\$ 5,000$ Rhode Island summer beach cottage is now a $\$ 500,000+$ yearround home). With Hurricane Katrina damage mounting into the hundreds of billions, we can safely say that an event of the magnitude of the Great New England Hurricane of 1938 would also cause tens of billions in damage in New York, Connecticut, and Rhode Island. Pielke and Landsea (1998) calculated the loss from the 1938 storm to be $\$ 16.6$ billion in 1995 dollars for the affected coastal counties only.

Most of the projects have not been tested with storm water elevations near their design elevation. Table 8 summarizes the elevations of the hurricanes and post-construction maximum elevations. The Charles River project is the one exception. J ust before it was formally dedicated, the Blizzard of 


\section{8 struck Boston, and the pumps proved their worth by preventing flooding of the Charles River Basin.}

Table 7. Summary of hurricane barrier project features.

\begin{tabular}{|c|c|c|c|c|c|}
\hline Project & $\begin{array}{l}\text { Design Storm } \\
\text { Elevation (ft, } \\
\text { NGVD) }\end{array}$ & $\begin{array}{l}\text { Project Elevation } \\
\text { (ft, NGVD) }\end{array}$ & $\begin{array}{l}\text { Total Levee, } \\
\text { Dike, Wall } \\
\text { Length (ft) }\end{array}$ & $\begin{array}{l}\text { Pump Capacity } \\
\text { (cu ft/sec) }\end{array}$ & Other Features \\
\hline $\begin{array}{l}\text { Charles R., } \\
\text { Boston, MA }\end{array}$ & $\begin{array}{l}4.35 \text { (Charles } \\
\text { R. basin elev.) }\end{array}$ & $12.35 \mathrm{ft}$ & 400 & $\begin{array}{l}8,400(6 @ \\
1,400 \mathrm{cfs} \\
\text { each })\end{array}$ & $\begin{array}{l}\text { Sluice gates, nav. locks. } \\
\text { Operated to maintain } \\
\text { Charles R. basin within } \\
\text { restricted range }\end{array}$ \\
\hline $\begin{array}{l}\text { New Bedford, } \\
\text { MA }\end{array}$ & 16.0 & $\begin{array}{l}20.022 .0 \text { (dike } \\
\text { extension) }\end{array}$ & 12,200 & $\begin{array}{l}240 \text { (Clark } \\
\text { Cove) }\end{array}$ & $\begin{array}{l}150 \mathrm{ft} \text { wide navigation } \\
\text { channel ( } 2 \text { sector gates } \\
\text { invert }=-39.0 \mathrm{ft} \text { NGVD) }\end{array}$ \\
\hline $\begin{array}{l}\text { Fox Point, } \\
\text { Providence, RI }\end{array}$ & 20.5 & 25.0 & 2,200 & $\begin{array}{l}7,000(5 \\
\text { pumps @ } \\
1,400 \mathrm{cfs} \\
\text { each) }\end{array}$ & $\begin{array}{l}700 \mathrm{ft} \text { concrete dam } \\
\text { with } 3 \text { tainter gates }\end{array}$ \\
\hline Pawcutuck, CT & $16.5 \mathrm{ft}$ & $17.0 \mathrm{ft}$ & 2,900 & 50 & \\
\hline New London, CT & $10.5 \mathrm{ft}$ & $14.5 \mathrm{ft}$ & 1,500 & 210 & $\begin{array}{l}\text { 96-in. diam. pressure } \\
\text { conduit from Truman } \\
\text { Brook to Shaws Cove }\end{array}$ \\
\hline Stamford, CT & $14.8 \mathrm{ft}$ & 17.0 and 18.0 & 10,600 & $\begin{array}{l}800(3 \\
\text { locations })\end{array}$ & $\begin{array}{l}90 \mathrm{ft} \text { wide navigation } \\
\text { channel (flap gate invert } \\
=-18.0 \mathrm{ft} \text { NGVD) }\end{array}$ \\
\hline $\begin{array}{l}\text { Raritan Bay, NJ } \\
\text { and Sandy Hook } \\
\text { Bay, NJ }\end{array}$ & 12.9 MSL & $\begin{array}{l}15.9 \text { (15.0 MSL) } \\
\text { (earthen levees } \\
\text { and dune) }\end{array}$ & 10,700 & $\begin{array}{l}490 \text { ( } 4 \text { pumps } \\
\text { @ } 122 \mathrm{cfs} \\
\text { each) }\end{array}$ & $\begin{array}{l}2,640 \mathrm{ft} \text { of dune }(15.8 \mathrm{ft} \\
\text { elev.) and beach fill }\end{array}$ \\
\hline
\end{tabular}

Table 8. Storm water levels.

\begin{tabular}{|l|l|l|l|l|}
\hline Location & $\begin{array}{l}\text { 1938 Max } \\
\text { (ft, NGVD) }\end{array}$ & $\begin{array}{l}\text { 1954 Max } \\
\text { (ft, NGVD) }\end{array}$ & $\begin{array}{l}\text { Highest Since Construction } \\
\text { (ft, NGVD) }\end{array}$ & Event \\
\hline $\begin{array}{l}\text { Charles R., Boston, } \\
\text { MA }\end{array}$ & & 9.89 & $\begin{array}{l}2 / 7 / 1978 \\
\text { blizzard }\end{array}$ \\
\hline New Bedford, MA & 12.5 & 11.9 & 7.6 & Hurricane Bob \\
\hline $\begin{array}{l}\text { Fox Point, } \\
\text { Providence, RI }\end{array}$ & 15.7 & 14.7 & 8.6 & Hurricane Bob \\
\hline Pawcutuck, CT & 11.1 & 10.4 & & Hurricane Gloria \\
\hline New London, CT & 9.7 & 8.9 & 6.0 & $\begin{array}{l}\text { 12/1992 } \\
\text { northeaster }\end{array}$ \\
\hline Stamford, CT & 11 & 10.3 & 10.1 & \\
\hline Source: New England District web page.
\end{tabular}


There is little information in the literature regarding flushing, sedimentation, or other environmental effects of the New England barriers. All except the Charles River dam were constructed in an era when environmental studies were minimal compared to today, and National Environmental Policy Act (NEPA) documents were not prepared for their construction. All were built to protect ports, industrial, and urban areas which were already extensively developed and modified from their natural (pre-industrial era) condition. New Bedford and Providence have serious pollution problems, but these were a legacy of three centuries of heavy industry, and by the time the barriers were installed in the 1960s, the heavy industry was largely gone. The Charles River, once grossly polluted, was also on the path to being cleaned when the new dam was completed in 1978. After 1969, NEPA documents were prepared for operation and maintenance activities of the Federally-run projects, but these reports did not address the construction years earlier.

New England streams in general have low sedimentation rates compared to streams in other parts of the country, therefore supplying little material to be trapped behind the barriers in Providence and New Bedford. Sedimentation would definitely need to be considered for barriers intended for the Gulf coast.

The gates at two of the projects, New Bedford and Raritan Bay, are not only in place for severe tropical storms but are used regularly at spring tide and other high water events to exclude water and prevent flooding of low areas. This ensures that the machinery is used regularly and is regularly maintained.

If larger ships will need access to New Bedford harbor in the future, the navigation gates would probably have to be totally rebuilt. This would be costly and disruptive. The gates in Providence will probably not be a limitation because they are upriver of the main commercial harbor and refineries. Plans for barriers in other locations should include options for expansion if there is a navigation component.

Long-term maintenance requirements were underestimated for the projects with mechanical components. In particular, the 1960s electromechanical controls need upgrading at Providence and probably also at New Bedford. The pumps at other sites may be in similar condition, well-maintained but with 1960s-vintage controls. At Raritan Bay, the 
beach will be renourished soon as part of a Federal project, but this probably should have been specifically scheduled in the original design.

Many people are unaware that the Corps of Engineers has built and efficiently operated hurricane barriers for more than 40 years. They are also unaware that these barriers have protected urban areas from flooding, although they have not been tested with severe storms of the magnitude of the 1938 and 1954 hurricanes. Both the Providence and New Bedford gate operators stated that since Hurricane Katrina, the Chief of Engineers and other officials have toured the projects, but before Katrina, they seldom entertained visitors. The New Bedford operator also said many local residents had no idea that the structure even existed and suggested a public relations effort would be well worthwhile.

At least six major challenges will confront designers of Gulf Coast hurricane barriers compared to the earlier projects:

1. Far more extensive environmental studies will have to be conducted.

2. Obtaining permits will be a multi-year and difficult process.

3. The foundation conditions will be more difficult and designs will have to consider potential settlement.

4. Rock was readily available for the New England projects from local quarries but will have to be brought in to the Gulf coast from distant stone sources.

5. Siltation will probably be more of a factor in the Gulf.

6. Post construction project and environmental monitoring will have to be conducted.

The New England and NewJ ersey barriers are excellent examples of cooperation and operational coordination between the USACE and municipal agencies. 


\section{References}

AEG. 2006. Engineering geology, young faults, and seismicity of the northern Narragansett Bay, Field trip number 4. Association of Environmental and Engineering Geologists 49th Annual Meeting, Boston, MA.

Allen, E. S. 1976. A wind to shake the world. Little Brown \& Co., New York, 288 p.

Brooks, C. F., and C. Chapman. 1945. The New England Hurricane of September, 1944. Geographical Review 35(1), 132-136.

Carbone, G. M. 2004. Hurricane Carol: The last big one. Providence J ournal, 29 August, 2004, available online: http:// www.projo.com/ news/ content/ projo_20040829_carol29.21f071.html, 24 November 2006.

Churchill, W. S. 1948. The Second World War, the gathering storm. Houghton Mifflin Co., Boston, MA.

Clowes, E. S. 1939. The Hurricane of 1938 on Eastern Long Island. Long Island, NY: Hampton Press, Bridgehampton.

Donnelly, J. P., S. S. Bryant, J . Butler, J . Dowling, L. Fan, N. Hausmann, P. Newby, B. Shuman, J . Stern, K. Westover, and T. Webb III. 2001. 700 yr sedimentary record of intense hurricane landfalls in southern New England. GSA Bulletin 113(6): 714-727.

Federal Writers' Project. 1938. New England Hurricane, a factual, pictorial record. Written and compiled by members of the Federal Writers' Project of the Works Progress Administration in the New England States, Hale, Cushman \& Flint. Boston, MA, $220 \mathrm{p}$.

Haberstroh, J . 1998. When the superstorm hit, Westhampton exhibit recalls deadly Hurricane of '38. Newsday (newspaper article dated Sunday, 20 September 1998).

Hall, M. 1986. The Charles, The people's river. David R. Goodine, Boston, MA, 108 p.

Harris, D. L. 1963. Characteristics of the hurricane storm surge. U. S. Weather bureau, Technical Data Report No. 48, Washington, DC: U. S. Department of Commerce.

Hicks, S. D. 1956. Some tidal characteristics of Narragansett Bay. Interim report, February 1956. Narragansett Marine Laboratory, 60 p. and plates. Kingston, RI: University of Rhode Island.

Housley, J . G. 1967. Effects of hurricane barrier on navigation conditions in East Passage Narragansett Bay, Rhode Island, hydraulic model investigation. Technical Report No. 2-754. Vicksburg, MS: U.S. Army Engineer Waterways Experiment Station. 
J arvinen, B. 2006. Storm tides in twelve tropical cyclones (including four intense New England Hurricanes). Hurricane Research Division, Atlantic Oceanographic and Meteorological Laboratory, 99 p. Available online: http:// www.aoml.noaa.gov/ hrd/Landsea/ 12Tides.pdf, 26 November 2006.

Ludlum, D. M. 1963. Early American hurricanes. American Meteorological Society, Boston, 198 pages.

McAleer, J . B., and G. E. Townsend. 1958. Hurricane protection planning in New England. J ournal of the Hydraulics Division 84(4), ASCE, pp. 1-36.

McAleer, J . B. 1963. Hurricane protection in New England. Shore \& Beach 31(1), 14-20 and $40-41$.

McLaughlin, R. T., and M. A. Anton. 1964. Study of hurricane barrier for Lower Narragansett Bay. Hydrodynamics Laboratory Report No. 66, Department of Civil Engineering, School of Engineering. Cambridge, MS: Massachusetts Institute of Technology, 97p.

Minsinger, E. E., (ed.). 1988. The 1938 Hurricane, an historical and pictorial summary. East Milton, MA: Blue Hill Observatory.

Morang, A. 1999. Coastal inlets research program, Shinnecock Inlet, New York, site investigation: Report 1: Morphology and historical behavior. Coastal and Hydraulics Laboratory Technical Report CHL-98-32. Vicksburg, MS: U.S. Army Engineer Waterways Experiment Station.

Morang, A., and C. B. Chesnutt. 2003. The Corps of Engineers' Coastal Mission Historical, Demographic, and Geologic Origins. IWR Report 03-NSMS-2, Institute for Water Resources, U.S. Army Corps of Engineers, Fort Belvoir, VA.

Morang, A., and C. B. Chesnutt. 2004. Historical Origins and Demographic and Geological Influences on Corps of Engineers Coastal Missions. Institute for Water Resources IWR Report 04-NSMS-4. Fort Belvoir, VA: U.S. Army Corps of Engineers.

Myers, V. A., and E. S. J ordan. 1956. Winds and pressure over the sea in the Hurricane of September 1938. Monthly Weather Review 84(7), 261-270.

Parkman, A. 1978. Army engineers in New England, the military and civil work of the Corps of Engineers in New England 1775-1975. Waltham, MA: U.S. Army Engineer Division, New England, 319 p.

Paulson, C. G. 1940. Hurricane floods of September 1938. U.S. Geological Survey WaterSupply Paper 867, 562 pages.

Pickering, G. A., and J . L. Grace, J r. 1965. Discharge characteristics of hurricane barrier, East Passage Narragansett Bay, Rhode Island, Hydraulic Model Investigation. Miscellaneous Paper No. 2-721, 8 p. and plates. Vicksburg, MS: U.S. Army Engineer Waterways Experiment Station. 
Pielke, R. A., Jr., and C. W. Landsea. 1998. Normalized hurricane damages in the United States: 1925-95. Weather and Forecasting 13(3):621- 631 (available online: http:/ / ams.allenpress.com/ archive/ 1520-0434/ 13/3/ pdf/i1520-0434-13-3621.pdf, 9 J anuary 2006).

Pierce, C. H. 1939. The meteorological history of the New England Hurricane of September 21, 1938. Monthly Weather Review 67(8):237-285.

Providence J ournal. 1938. The great hurricane and tidal wave $\star$ Rhode Island September 21, 1938. Providence, RI: ProvidenceJ ournal Company.

Public Health Service. 1960. Effects of proposed hurricane barriers on water quality of Narragansett Bay. New York, NY: U.S. Department of Health, Education, and Welfare, 23 p. and appendices.

Saila, S. 1962. Proposed hurricane barriers related to Winter Flounder movements in Narragansett Bay. Transactions of the American Fisheries Society 92(2)189-195.

Simmons, H. B. 1964. Protection of Narragansett Bay from hurricane surges: Summary report: Hydraulic model investigation. Technical Report No. 2-662, 98 p. and plates. Vicksburg, MS: U.S. Army Engineer Waterways Experiment Station.

Tannehill, I. R. 1938. Hurricane of September 16 to 22, 1938. Monthly Weather Review 66(9):286-288.

U.S. Army Engineer Division, New England. 1961. Hurricanes survey interim report, New London, Connecticut, Appendices. Waltham, MA: New England Division, 26 April 1961.

U.S. Army Engineer Division, New England. 1963. Narragansett Bay hurricane flood protection, Rhode Island and Massachusetts, study of Lower Bay hurricane barriers. Waltham, MA, New England Division, 15 October 1963 (Rev. 12, December 1963).

U.S. Army Engineer Division, New England. 1972. Final environmental statement, operation and maintenance of New Bedford hurricane barrier. Waltham, MA: New England Division, September 1972, 30 p.

U.S. Army Engineer Division, New England. 1973. Charles River Dam, Boston, Massachusetts: Final environmental statement. Waltham, MA: New England Division.

U.S. Army Engineer District, New York. 1960. Raritan Bay and Sandy Hook Bay, New J ersey, cooperative beach erosion control and interim hurricane study (Survey). New York, NY: New York District, November 1960, 39 p. with plates and appendices.

U.S. Army Engineer District, New York. 1963. Raritan Bay and Sandy Hook Bay, New J ersey, beach erosion and hurricane project, General Design Memorandum No. 1, Madison and Matawan Townships. New York, NY: NewYork District J uly 1963, 44 p. with plates and appendices. 
U.S. Army Engineer District, New York. 1964. Raritan Bay and Sandy Hook Bay, New J ersey, beach erosion and hurricane project: General design memorandum No. 2, Keansburg and East Keansburg, N.J . New York, NY: New York District J une 1964, $54 \mathrm{p}$. with plates and appendices.

U.S. Army Engineer Division, North Pacific. 1977. Fish ladders for Charles River Dam, Charles River, Massachusetts: Hydraulic Model Investigation. Portland, OR: North Pacific Division, 28 p.

U.S. Army Enginer Waterways Experiment Station. 1959a. Effects of lower bay barriers on salinities, shoaling, and pollution in Narragansett Bay : Hydraulic model investigation. Interim report, J anuary 1959, 39 p. and plates. Vicksburg, MS: U.S. Army Engineer Waterways Experiment Station, Vicksburg.

U.S. Army Engineer Waterways Experiment Station. 1959b. Effects of Fox Point barrier on water temperatures: Model study of Narragansett Bay. Interim report, September 1959, 14 p. and plates. Vicksburg, MS: U.S. Army Engineer Waterways Experiment Station.

Vallee, D. R., and M. R. Dion. 1998. Southern New England tropical storms and hurricanes: A ninety-eight year summary 1909-1997. Taunton, MA: National Weather Service.

Wiegel, R. L. 1993. Hurricane and coastal storm barriers in New England. Shore and Beach 61(2):30-49.

Wexler, R. 1939. The filling of the New England Hurricane of September 1938. Bulletin of the American Meteorological Society 20(7):277-281.

Whitehill, W. M. 1968. Boston, a topographical history. Second edition, enlarged. Cambridge, MA: Belknap Press of Harvard University Press, 299 p. 


\section{Appendix A: Bibliography of the Great New England Hurricane of 1938}

\section{Printed Documents}

Allen, E. S. 1976. A wind to shake the world. NewYork, NY: Little Brown \& Co., 288 p.

Bennett, H. H. 1939. A permanent loss to New England: Soil erosion resulting from the hurricane. Geographical Review 29:196-204.

Bennett, J. P. (ed.). 1998. The 1938 hurricane as we remember it, Volume II: A collection of memories from Westhampton Beach and Quogue Areas. Quogue Historical Society, Quogue, NY, and Westhampton Beach Historical Society, Westhampton Beach, NY (Searles Graphics, Inc., East Patchogue, NY).

Brickner, R. K. 1988. The Long Island Express, tracking the Hurricane of 1938. Batavia, NY: Hodgins Printing Co. (with historical data by David M. Ludlum).

Brooks, C. F. 1939. Hurricanes into New England: Meteorology of the storm of September 21, 1938. Geographical Review 29:119-127.

Burns, Cherie. 2005. The Great Hurricane: 1938. New York, NY: Atlantic Monthly Press, $230 \mathrm{p}$.

Clowes, E. S. 1939. The Hurricane of 1938 on Eastern Long Island. Long Island, NY: Hampton Press, Bridgehampton.

Cummings, M. 2006. Hurricane in the Hamptons, 1938. Arcadia Publishing, 128 p.

Federal Writers' Project. 1938. New England Hurricane, a factual, pictorial record. Written and compiled by members of the Federal Writers' Project of the Works Progress Administration in the New England States, Hale, Cushman \& Flint, Boston, MA.

Goudsouzian, A. 2004. The Hurricane of 1938 (New England Remembers). Commonwealth Editions, 90 p.

Hendrickson, R. G. 1996. Winds of the fish's tail. Mattituck, NY: Amereon Ltd.

Minsinger, E. E., (ed.). 1988. The 1938 Hurricane, an Historical and Pictorial Summary. East Milton, MA: Blue Hill Observatory.

Myers, V. A., and E. S. J ordan. 1956. Winds and pressure over the sea in the Hurricane of September 1938. Monthly Weather Review 84(7):261-270.

Perry, M. B., and P. D. Shuttleworth, (ed.). 1988. The 1938 Hurricane as we remember it, a collection of memories from Westhampton Beach and Quogue. Quogue Historical Society, Quogue, NY (prepared by the Quogue Historical Society on the fiftieth anniversary of the 1938 Hurricane). 
Pielke, J r., R. A., and C. W. Landsea. 1998. Normalized hurricane damages in the United States: 1925-1995. Weather and Forecasting 13:621-631.

Pierce, C. H. 1939. The meteorological history of the New England Hurricane of September 21, 1938. Monthly Weather Review 67(8):237-285.

Providence J ournal. 1938. The great hurricane and tidal wave $\star$ Rhode Island September 21, 1938. Providence, RI: Providence J ournal Company.

Scotti, R. A. 2003. Sudden sea: The Great Hurricane of 1938. Chapter \& Verse, Inc., $278 \mathrm{p}$.

Shaw, O. 1939. History of the storms and gales on Long Island; and Quick, D. The Hurricane of 1938. Bay Shore, NY: Long Island Forum (limited edition of 500 copies).

Tannehill, I. R. 1938. Hurricane of September 16 to 22, 1938. Monthly Weather Review 66(9):286-288.

Vallee, D. R. 1993. Rhode Island hurricanes and tropical storms, A fifty-six year summary 1936-1991. NOAA Technical Memorandum NWS-ER-86. Bohemia, NY: NOAA, $62 \mathrm{pp}$.

Vallee, D. R., and M. R. Dion. 1998. Southern New England tropical storms and hurricanes, a ninety-eight year summary 1909-1997. Taunton, MA: National Weather Service.

Wexler, R. 1939. The filling of the New England Hurricane of September 1938. Bulletin of the American Meteorological Society 20(7):277-281.

Wood, F. J . 1976. The strategic role of Perigean spring tides in nautical history and North American coastal flooding, 1635-1976. U.S. Department of Commerce, National Oceanic and Atmospheric Administration, Washington, DC: U.S. Government Printing Office.

\section{Web Pages}

Geocities: http:// www.geocities.com/ hurricanene/ hurr1938.htm, 15 November 2006.

Intellicast (meteorology): http:/ / www.intellicast.com/ DrDewpoint/ Library/ 1123, 15 November 2006

New Haven Railroad Historical and Technical Association: http:/ /www.gis.net/ \%7Ewreidy/htdocs/images0998.htm, 15 November 2006.

Newsweek: http:// www.msnbc.msn.com/id/3067870, 15 November 2006.

National Weather Service: http:// www.erh.noaa.gov/ er/ nerfc/ historical/ sept1938.htm, 15 November 2006.

Public Broadcasting Service (PBS): http:// www.pbs.org/wgbh/ amex/ hurricane38/index.html, 15 November 2006. 
South Station (private page): http:// www.southstation.org/ hurr1.htm, 15 November 2006.

Stamford Historical Society: http:// www.stamfordhistory.org/ph_1002.htm, 15 November 2006.

Suffolk County Community College: http:// www2.sunysuffolk.edu/mandias/38hurricane, 15 November 2006.

Westport (MA) Historical Society: http:// www.westporthistory.com/news/archives/2003_09.html, 16 November 2006. 


\section{Appendix B: Bibliography of Hurricane Carol, 1954}

\section{Printed Documents}

FitzGerald, G. M. (compiler). 2005. Hurricane Carol 50 years later: A Collection of memories past and present. Lulu.com, $65 \mathrm{p}$.

Mathers, Myra M., William H. Mathers, Eugene W Stetson, J r., and Mohn D Mocomber. 1954. Hurricane Carol (four essays), Overboard in Hurricane Carol - Damage to Pendragon - Excerpt from Log of Grey Mist - Experiences in Sakonnet. Selfpublished (ASIN B000MC2T6E).

Orloff, C. T., D. R. Vallee, and W. E. Minsinger. 2004. Carol at 50: Remembering her fury: A historical and pictorial summary of Hurricane Carol. East Milton, MA: Blue Hill Observatory.

Providence J ournal. 1954. Hurricane Carol lashes Rhode Island, August 31, 1954. Providence, RI: ProvidenceJ ournal Company.

\section{Web Page}

Stone, Greg. 2003. Remembering Hurricane Carol. http://giveyoujoy.net/natural_high/hurricane_carol/index.htm, 24 November 2006. 


\section{Appendix C: USACE Hurricane and Flood Potential Reports and General Design Memorandums for New England and New Jersey Coastal Waters and District of Columbia1}

\section{Massachusetts}

\section{New Bedford}

U.S. Army Engineer Division, New England. 1961. New Bedford-Fairhaven hurricane barrier, New Bedford Harbor, Massachusetts, hurricane protection project. Design Memorandum No.1, Hydrology and Hydraulics. Waltham, MA: New England Division, (No. 1 of a series of 11 memorandums detailing construction, design, and materials).

\section{Wareham}

U.S. Army Engineer Division, New England. 1961. Hurricane survey interim report, Wareham-Marion, Massachusetts. Waltham, MA: New England Division, 25 October 1961.

U. S. Army Engineer Division. 1961. Hurricane survey interim report, WarehamMarion, Massachusetts, Appendices. Waltham, MA: New England Division, 25 October 1961.

\section{Rhode Island}

\section{Narragansett Bay:}

McAleer, J . B. 1964. Hurricane studies for Narragansett Bay. Waltham, MA: U.S. Army Engineer Division, New England, 15J une 1964, 15 p. and plates.

U.S. Army Engineer Division, New England. 1957. Hurricane survey interim report, Narragansett Bay Area. Waltham, MA: New England Division, February 1957.

U.S. Army Engineer Division, New England. 1960. Hurricane survey interim report, Narragansett Pier, Rhode Island. Waltham, MA: New England Division, 15 April 1960, 57 p. and plates.

\footnotetext{
1 These documents are in the library at the U.S. Army Engineer Waterways Experiment Station, Vicksburg, MS. Few or none are available in electronic format. This list may not be comprehensive.
} 
U.S. Army Engineer Division, New England. 1960. Hurricane survey interim report, Narragansett Pier, Rhode Island, Appendices. Waltham, MA: New England Division 15 April 1960.

U.S. Army Engineer Division, New England. 1963. Narragansett Bay hurricane flood protection, Rhode Island and Massachusetts, study of Lower Bay hurricane barriers. Waltham, MA: New England Division, 15 October 1963 (Rev. 12 December 1963).

U.S. Army Engineer Division, New England. 1964. Hurricane survey interim report, Rhode Island coastal and tidal areas. Waltham, MA: New England Division, 15 May 1964, 10 p., plates, and appendices.

\section{Point Judith:}

U.S. Army Engineer Division, New England. 1962. Water resources development interim report, Point J udith, Rhode Island. Waltham, MA: New England Division, 24 J anuary 1962, 52 p. and plates.

U.S. Army Engineer Division, New England. 1962. Water resources development interim report, Point J udith, Rhode Island, Appendices. Waltham, MA: New England Division, 24J anuary 1962.

\section{Providence:}

U.S. Army Engineer Division, New England. 1959. Fox Point hurricane barrier, Providence River, Providence, Rhode Island. Design Memorandum No.1, site geology. Waltham, MA: New England Division (No. 1 of a series of 14 memorandums detailing construction, design, and materials).

U.S. Army Engineer Division, New England. 1959. Fox Point hurricane barrier, Providence River, Providence, Rhode Island; special studies for river section construction, V.1. Waltham, MA: New England Division.

U.S. Army Engineer Division, New England. 1959. Fox Point hurricane barrier, Providence River, Providence, Rhode Island; special study of construction methods for the cooling water canal wall, V.2. Waltham, MA: New England Division.

\section{Westerly:}

U.S. Army Engineer Division, New England. 1963. Water resources development interim report, Westerly, Rhode Island. Waltham, MA: New England Division, 30 September 1963.

U.S. Army Engineer Division, New England. 1963. Water resources development interim report, Westerly, Rhode Island, Appendices. Waltham, MA: New England Division, 30 September 1963. 


\section{Connecticut}

\section{Fairfield:}

U.S. Army Engineer Division, New England. 1962. Hurricane survey interim report, Fairfield, Connecticut. Waltham, MA: New England Division, 30 J anuary 1962, $17 \mathrm{p}$. and plates.

\section{Mystic:}

U.S. Army Engineer Division, New England. 1960. Hurricane survey interim report, Mystic, Connecticut. Waltham, MA: New England Division, 15J uly 1960, 43 p. and plates.

U.S. Army Engineer Division, New England. 1960. Hurricane survey interim report, Mystic, Connecticut, Appendices. Waltham, MA: New England Division, 15J uly 1960.

\section{New London:}

U.S. Army Engineer Division, New England. 1961. Hurricane survey interim report, New London, Connecticut. Waltham, MA: New England Division, 26 April 1961, 42 p. and plates.

U.S. Army Engineer Division, New England. 1961. Hurricane survey interim report, New London, Connecticut, Appendices. Waltham, MA: New England Division, 26 April 1961.

U.S. Army Engineer Division, New England. 1962. Preliminary report on study of hurricane wave protection, New London Harbor, Connecticut. Prepared for Commandant, $3^{\text {rd }}$ Naval District, United States Navy. Waltham, MA: New England Division, 24 May 1962, 17 p. and plates.

U.S. Army Engineer Division, New England. 1965. New London hurricane barrier, New London, Connecticut. Design Memorandum No. 1, Hurricane Tidal Hydraulics. Waltham, MA: New England Division, October 1965, 16 p and plates, (No. 1 of a series of six memorandums detailing construction, design, and materials).

U.S. Army Engineer Division, New England. 1977. New London hurricane barrier, New London, Connecticut. Design Memorandum No. 2, General Design (Revised), J uly 1977. Waltham, MA: New England Division.

\section{Pawcatuck:}

U.S. Army Engineer Division, New England. 1961. Pawcatuck local protection project, hurricane protection, Pawcatuck River, Connecticut. General Design Memorandum. Waltham, MA: New England Division September 1961.

\section{Stratford:}

U.S. Army Engineer Division, New England. 1961. Hurricane Survey Interim Report, Stratford, Connecticut. Waltham, MA: New England Division, 22 March 1963. 
U.S. Army Engineer Division, New England. 1961. Hurricane survey interim report, Stratford, Connecticut, Appendices. Waltham, MA: New England Division, 22 March 1963.

\section{Westport:}

U.S. Army Engineer Division, New England. 1961. Hurricane survey interim report, Westport, Connecticut. Waltham, MA: New England Division, 1961.

U.S. Army Engineer Division, New England. 1961. Hurricane survey interim report, Westport, Connecticut, Appendices. Waltham, MA: New England Division, 1961.

\section{New Jersey}

\section{Raritan and Sandy Hook Bays:}

U.S. Army Engineer District, New York. 1960. Raritan Bay and Sandy Hook Bay, New J ersey, cooperative beach erosion control and interim hurricane study (survey). New York, NY: New York District, November 1960, 39 p. with plates and appendices.

U.S. Army Engineer District, New York. 1963. Raritan Bay and Sandy Hook Bay, New J ersey, beach erosion and hurricane project. General Design Memorandum No. 1, Madison and Matawan Townships. New York, NY: New York District, J uly 1963, 44 p. with plates and appendices.

U.S. Army Engineer District, New York. 1964. Raritan Bay and Sandy Hook Bay, New J ersey, beach erosion and hurricane project. General Design Memorandum No. 2, Keansburg and East Keansburg, N.J . New York, NY: New York District, J une 1964, $54 \mathrm{p}$. with plates and appendices.

U.S. Army Engineer District, New York. 1963. Raritan Bay and Sandy Hook Bay, New J ersey, beach erosion and hurricane project. Supplement to General Design Memorandum No. 2. Keansburg and East Keansburg, NJ : New York District.

\section{Washington, DC, Metropolitan Area}

U. S. Army Engineer District, Baltimore. 1963. Hurricane survey, Washington, DC, Metropolitan Area. Survey Report. Baltimore, MD: Baltimore District, 15 May 1963, (available online: http:// www.csc.noaa.gov/ hes/images/ pdf/ HURRSURVEY_METRO_DC.pdf, 5J anuary 2007). 


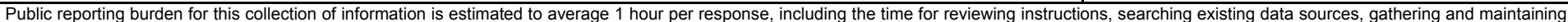

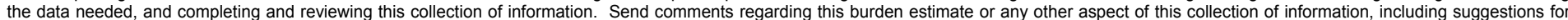

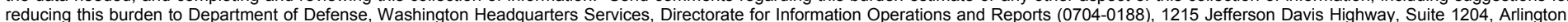

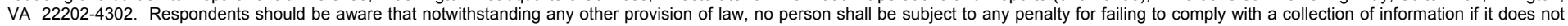
display a currently valid OMB control number. PLEASE DO NOT RETURN YOUR FORM TO THE ABOVE ADDRESS.

\begin{tabular}{l|c}
$\begin{array}{l}\text { 1. REPORT DATE (DD-MM-YYYY) } \\
\text { September } 2007\end{array}$ & $\begin{array}{c}\text { 2. REPORT TYPE } \\
\text { Final report }\end{array}$ \\
\hline
\end{tabular}

4. TITLE AND SUBTITLE

Hurricane Barriers in New England and New Jersey - History and Status After Four Decades

3. DATES COVERED (From - To)

5a. CONTRACT NUMBER

5b. GRANT NUMBER

5c. PROGRAM ELEMENT NUMBER

6. AUTHOR(S)

5d. PROJECT NUMBER

Andrew Morang

5e. TASK NUMBER

5f. WORK UNIT NUMBER

7. PERFORMING ORGANIZATION NAME(S) AND ADDRESS(ES)

8. PERFORMING ORGANIZATION REPORT NUMBER

Coastal and Hydraulics Laboratory

U.S. Army Engineer Research and Development Center

ERDC/CHL TR-07-11

3909 Halls Ferry Road

Vicksburg, MS 39180-6199

9. SPONSORING / MONITORING AGENCY NAME(S) AND ADDRESS(ES)

U.S. Army Engineer District, New Orleans

7400 Leake Avenue, New Orleans, LA 70118-3651

10. SPONSOR/MONITOR'S ACRONYM(S)

11. SPONSOR/MONITOR'S REPORT NUMBER(S)

12. DISTRIBUTION / AVAILABILITY STATEMENT

Approved for public release; distribution is unlimited.

\section{SUPPLEMENTARY NOTES}

\section{ABSTRACT}

In response to renewed studies of potential hurricane barriers across Lake Pontchartrain, the U.S. Army Engineer Research and Development Center conducted a survey of the New England hurricane barriers. This survey revealed a number of common factors pertaining to the projects. First, most of the projects have not been tested with storm water elevations near their design elevation. An exception is the Charles River dam, which helped prevent flooding in Boston during the Blizzard of 1978. For the lower levels experienced, all projects performed as designed. Second, there is little information in the literature regarding flushing, sedimentation, or other environmental effects of the New England barriers. All except Charles River were constructed in an era when environmental studies were minimal compared to today. Third, long-term maintenance requirements were underestimated for the projects with mechanical components. In particular, the 1960s electromechanical controls at Providence and New Bedford need upgrading. Fourth, many people are unaware that the Corps of Engineers has built and efficiently operated hurricane barriers for more than 40 years. A public education campaign would be beneficial to the USACE. The New England and New Jersey barriers are excellent examples of cooperation and operational coordination between the USACE and municipal agencies.

\section{SUBJECT TERMS}

Hurricane Carol

Great New England Hurricane

16. SECURITY CLASSIFICATION OF:

\begin{tabular}{|l|l|}
\hline $\begin{array}{l}\text { a. } \text { REPORT } \\
\text { UNCLASSIFIED }\end{array}$ & $\begin{array}{l}\text { b. ABSTRACT } \\
\text { UNCLASSIFIED }\end{array}$ \\
\hline
\end{tabular}

Fox Point

New Bedford

Flood walls

c. THIS PAGE

UNCLASSIFIED
Sector gates

Charles River

\begin{tabular}{|l|c|}
$\begin{array}{l}\text { 17. LIMITATION } \\
\text { OF ABSTRACT }\end{array}$ & $\begin{array}{c}\text { 18. NUMBER } \\
\text { OF PAGES }\end{array}$ \\
& 116 \\
\hline
\end{tabular}

19a. NAME OF RESPONSIBLE PERSON

19b. TELEPHONE NUMBER (include area code) 


\section{ABSTRACT (continued)}

At least five major challenges will confront designers of Gulf Coast hurricane barriers compared to the earlier projects:

- Far more extensive environmental studies will have to be conducted today.

- Obtaining permits will be a multi-year and difficult process.

- The foundation conditions would probably be more difficult and designs would have to consider potential settlement.

- Rock was readily available for the New England projects from local quarries but will have to be brought in to the Gulf coast from distant stone sources.

- Siltation will be more of a factor in Louisiana projects.

- Post-construction project and environmental monitoring will be needed. 